\title{
O INTERESSE SEGURÁVEL
}

Dissertação apresentada à Comissão Julgadora da Faculdade de Direito da Universidade de São Paulo, como exigência parcial para obtenção do título de Mestre em Direito Civil, sob a orientação do Professor Doutor Alcides Tomasetti Junior.

Universidade de São Paulo

Faculdade de Direito

São Paulo, 2011 


\section{BANCA EXAMINADORA:}

1. Orientador: Alcides Tomasetti Junior

2. Examinador(a):

3. Examinador(a): 
Aos meus pais Joaquim e Angelica, por tudo que sempre fizeram por mim.

Ao meu irmão Mauricio, sempre presente em minha vida, in memoriam.

Ao Fred, por seu amor, incentivo e paciência. 


\section{AGRADECIMENTOS}

Registro meus agradecimentos a todos aqueles que contribuíram de alguma maneira para a consecução deste trabalho, em especial:

- ao Professor Alcides Tomasetti Junior, meu Orientador, pela confiança e paciência, bem como pelos ensinamentos que me trouxeram a compreensão de outra dimensão do Direito;

- às Professoras Vera Helena de Mello Franco e Giselda Maria Fernandes Novaes Hironaka, integrantes da banca de qualificação, pelos apontamentos e críticas que possibilitaram o aperfeiçoamento da sistematização da matéria e a abordagem de pontos-chave que não haviam sido incluídos no projeto de pesquisa;

- aos ilustres Advogados Ayrton Pimentel e Joaquim Barbosa de Oliveira, pelo desprendimento de colocar mais de 40 anos de experiência e o conhecimento do direito do seguro na leitura deste texto, apontando falhas e suscitando reflexões;

- ao colega de Mestrado e de monitoria Marcel Simões, pelas contribuições essenciais sobre a teoria geral do direito;

- à Professora e amiga Doutora Angelica Carlini, pelo auxílio e apoio, desde o início do Mestrado, na indicação bibliográfica, na escolha do tema e na estruturação da pesquisa;

- ao amigo e Advogado empresarial Samy Sanches de Almeida, pelos ensinamentos e envio de artigos sobre os créditos derivativos e a crise financeira de 2008 ;

- aos colegas de escritório, pelo apoio, seja na coleta de material em várias bibliotecas, seja assumindo parte expressiva do trabalho e do cotidiano do escritório a fim de permitir meu afastamento ocasional para a elaboração deste estudo; 
- ao Professor Robert Merkin e aos advogados Fred Hawke e Robert Pinzur, pelo envio de material estrangeiro, que foram fundamentais para a pesquisa;

- aos meus pais Angélica e Joaquim, pelo carinho e apoio incondicional;

- ao Fred, por ter abdicado reiteradamente de nossas férias, noites e fins de semana para que este trabalho pudesse ser escrito. 
Se o contrato deve atender ao interesse geral, não há contrato mais significativamente voltado ao interesse geral do que o contrato de seguro.

Miguel Reale Junior - III Fórum de Direito do Seguro "José Sollero Filho" 


\section{RESUMO}

O presente trabalho tem por escopo o estudo jurídico do interesse segurável, elemento essencial do contrato de seguro, entendido como a relação existente entre o segurado e a coisa ou a pessoa sujeita ao risco. O tema é desenvolvido tendo por base a análise estrutural e funcional do interesse segurável, sua evolução legislativa no Brasil e consequências no contrato de seguro, no que tange tanto ao seguro de danos como ao seguro de pessoas. A análise pauta-se, em particular, no Código Civil brasileiro hodierno e no Código de 1916. Em razão da inexistência de literatura nacional específica sobre o assunto, o estudo é ilustrado, na medida do possível, com o tratamento da matéria na legislação estrangeira, na Jurisprudência nacional e no Projeto de Lei n. 3.555/2004.

Palavras-chave: Interesse Segurável; Contrato de Seguro; Risco; Código Civil - Projeto de Lei n. 3.555/2004. 


\begin{abstract}
The present work aims the legal study of the insurable interest, a essencial element of the insurance contract, understood as the relationship between a person and a thing or another person subject to risk. The subject will be developed from the structural and functional analysis of the insurable interest, its legislative developments in Brazil and its consequences in the insurance contract, both regarding indemnity and non-indemnity insurance contracts. The analysis is guided, in particular, by the Brazilian Civil Code and former Code of 1916. Considering the lack of specific national literature on the subject, the study is illustrated, as far as possible, with examples of foreign Law, case law and the Law Project n. 3.555/2004.
\end{abstract}

Keywords: Insurable Interest; Contract of Insurance; Risk; Civil Code - Law Project n. $3.555 / 2004$. 


\section{SUMÁRIO}

Introdução

\section{CAPÍTULO 1 - NOÇÕES PRELIMINARES SOBRE O INTERESSE} SEGURÁVEL

1.1 Etimologia e evolução do significado de interesse ................................................ 16

1.1.1 Acepção jurídica de interesse ....................................................................... 17

1.2 Interesse na concepção securitária ……………………………………………... 19

1.3 Antecedentes históricos: as primeiras legislações sobre "interesse segurável" ..... 20

1.4 A diferença de tratamento do "interesse segurável" nos seguros de danos e de pessoas

1.5 As várias teorias sobre o contrato de seguro: a busca por um conceito unitário aplicável ao seguro de danos e de pessoas ........................................................ 25

1.5.1 A Teoria Indenitária Tradicional ............................................................... 25

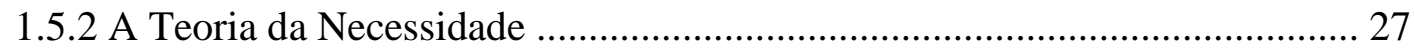

1.5.3 A Teoria da Empresa ………………………………………………. 29

1.5.4 A Nova Teoria Indenitária …………………………………………..... 30

1.5.5 A Teoria da Transferência do Risco …………………………………….... 32

1.6 O modelo adotado pela legislação brasileira: a teoria do interesse legítimo ........... 33

\section{CAPÍTULO 2 - INTERESSE SEGURÁVEL: CONCEITO}

E ELEMENTOS _.............................................................................................. 37

2.1 O interesse na legislação brasileira …............................................................ 37

2.2 As correntes doutrinárias sobre a definição de interesse segurável ...................... 41 
2.2.1 Interesse como relação - corrente majoritária 41

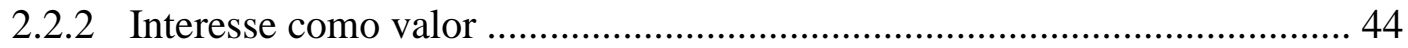

2.2.3 Interesse como expectativa de perda patrimonial ....................................46

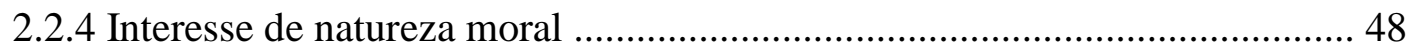

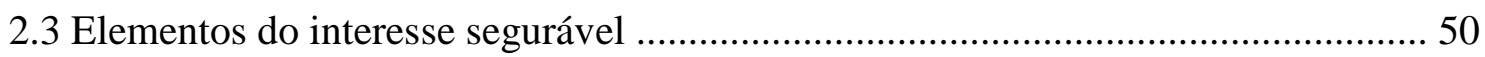

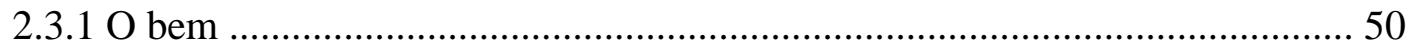

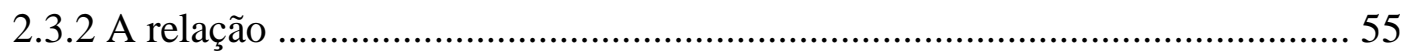

2.3.2.1 Fato constitutivo da relação ............................................................ 55

2.3.2.2 Interesse econômico versus moral ..................................................... 58

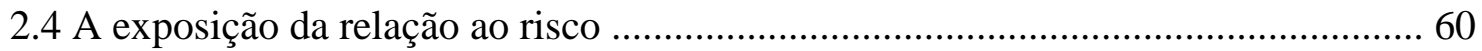

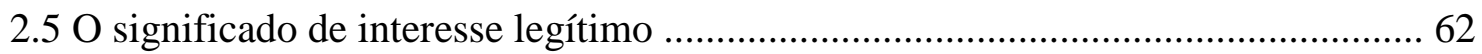

\section{CAPÍTULO 3- INTERESSE SEGURÁVEL: NATUREZA}

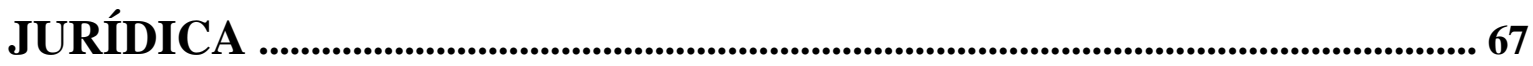

3.1 Os elementos do contrato de seguro na legislação brasileira ................................. 68

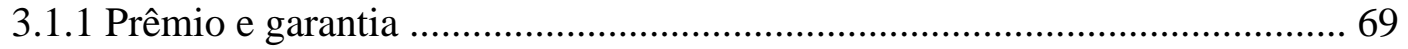

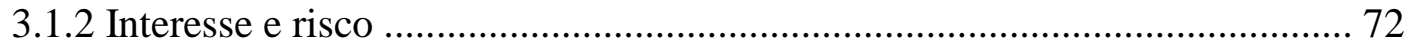

3.1.3 A controvérsia sobre a empresarialidade como elemento do contrato de

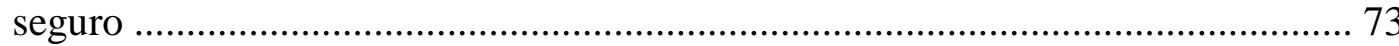

$3.2 \mathrm{O}$ interesse como objeto do contrato de seguro ................................................. 75

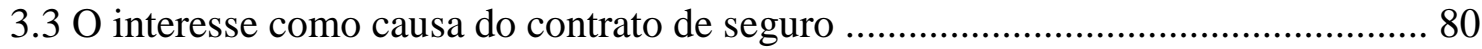

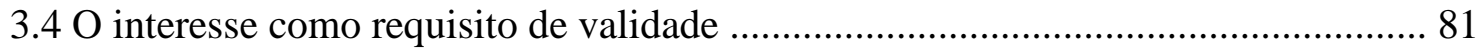

\section{CAPÍTULO 4- O INTERESSE SEGURÁVEL NO SEGURO DE}

4.1 Diferenciação entre o seguro de coisa e o seguro de responsabilidade civil 
4.2.1 $\mathrm{O}$ interesse material

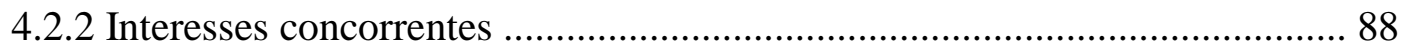

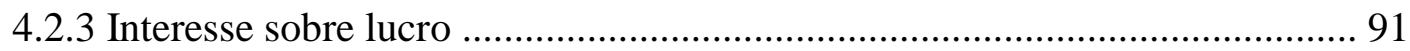

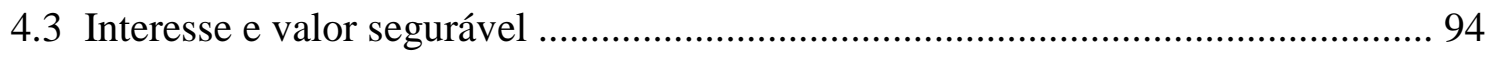

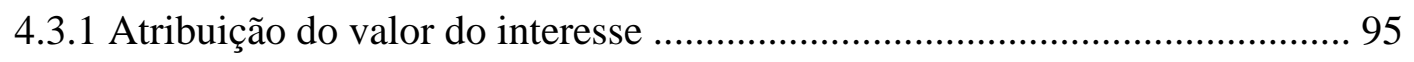

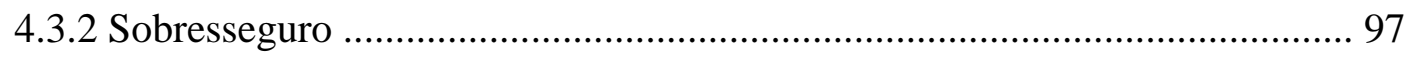

4.3.3 Infrasseguro: a cláusula de rateio ou regra proporcional .......................... 101

4.3.4 Pluralidade de seguros ................................................................. 103

\section{CAPÍTULO 5 - O INTERESSE SEGURÁVEL NO SEGURO}

DE RESPONSABILIDADE CIVIL ..................................................................... 108

5.1 O tratamento da matéria no Código Civil de 1916 ............................................ 108

5.2 O regime jurídico instituído pelo novo Código Civil ........................................ 110

5.2.1 Seguro obrigatório de responsabilidade civil ....................................... 110

5.3 O desenvolvimento da responsabilidade civil e os reflexos no interesse segurável

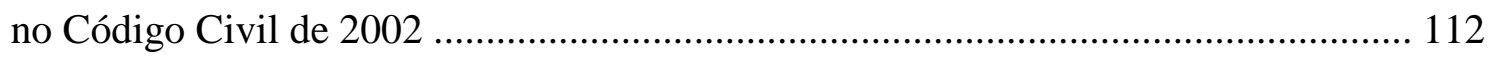

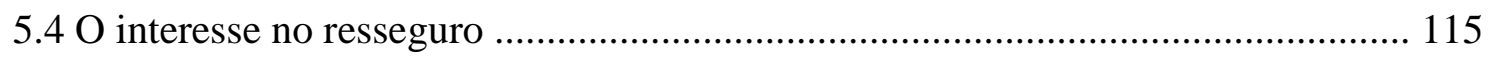

5.5 Interesse e valor segurado no seguro de responsabilidade civil .......................... 116

\section{CAPÍTULO 6 - O INTERESSE SEGURÁVEL NO SEGURO}

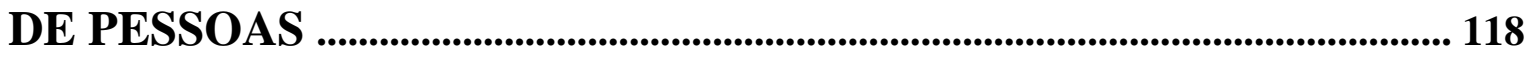

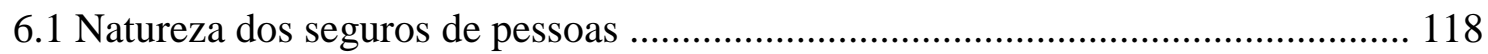

6.2 Noções essenciais sobre seguros de pessoas ...................................................... 119

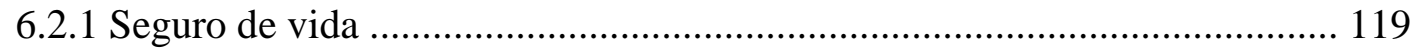

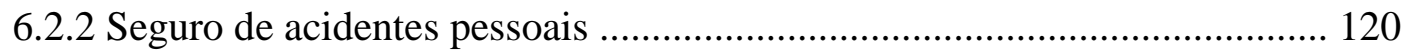

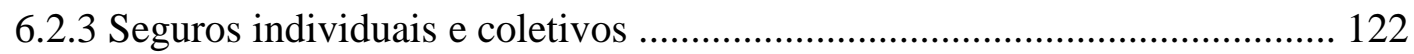

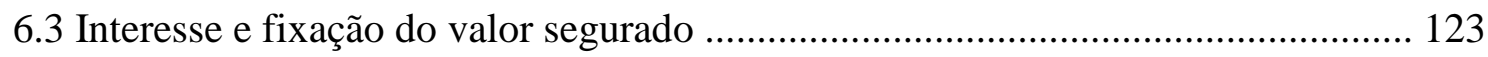


6.4 Figurantes no seguro de pessoas e interesse segurável

6.4.1 Interesse do estipulante

6.4.2 Interesse do contratante no seguro sobre a vida de outrem 127

6.4.3 Interesse do beneficiário

CONCLUSÃO 134

REFERÊNCIAS 143 


\section{INTRODUÇÃO}

Nos termos do art. 757 do Código Civil de 2002, "pelo contrato de seguro, o segurador se obriga, mediante o pagamento do prêmio, a garantir interesse legítimo do segurado, relativo a pessoa ou a coisa, contra riscos predeterminados".

A redação do artigo em comento representou uma inovação positiva em relação ao art. 1.432 do Código Civil de 1916 que definia o contrato de seguro como "aquele pelo qual uma das partes se obriga para com a outra, mediante a paga de um prêmio, a indenizála do prejuízo resultante de riscos futuros, previstos no contrato".

Figura entre outras inovações, o fato de a atual definição colocar em destaque o interesse segurável, evidenciando que a garantia do contrato de seguro não recai propriamente sobre a coisa ou a pessoa, mas sim sobre o interesse que o segurado possui em relação a elas.

O exame da legislação de alguns países aponta a inexistência de consenso sobre a definição, natureza jurídica e aplicação do interesse segurável, em razão de fatores históricos e da adoção ou não de um conceito unitário para o contrato de seguro. Não são poucos os que sustentam que a sua aplicação se destina unicamente aos seguros de dano, uma vez que não reconhecem a função indenizatória nos seguros de pessoas.

$\mathrm{Na}$ legislação brasileira hodierna, o interesse segurável é um dos elementos essenciais do contrato de seguro, apontado pela doutrina majoritária como o seu próprio objeto, seja no seguro de danos, seja no seguro de pessoas.

A compreensão do interesse segurável é essencial para o estudo do contrato de seguro. É o interesse que condiciona o conteúdo do contrato, que determina seu valor e que indica quem pode contratar o seguro por possuir um legítimo interesse de preservação do bem. A titularidade do interesse não se confunde com a titularidade sobre o bem; daí por que um mesmo bem pode gerar uma multiplicidade de seguros, com diferentes titulares.

A atuação do interesse segurável é diferente nos seguros de danos e nos seguros de pessoas. Dentre outras diferenças, pode-se asseverar que, nos seguros de danos, é a medida da garantia e da indenização; nos seguros de pessoas, impede que o seguro sobre a vida de terceiro se converta em mera especulação. 
Em vista de tais considerações, o presente estudo sobre o interesse segurável é dividido em duas partes: a primeira (Capítulos 1, 2 e 3) apresenta um estudo do contexto histórico e doutrinário para o seu desenvolvimento, conceito e natureza jurídica; e a segunda (Capítulos 4, 5 e 6) analisa a importância específica do interesse nos seguros de dano, subdividido em seguros de coisa e de responsabilidade civil e nos seguros de pessoa.

O primeiro capítulo apresenta algumas noções preliminares, necessárias à compreensão do estudo sobre o interesse segurável. A primeira parte do capítulo destina-se a uma breve análise dos vários significados de interesse, na linguagem cotidiana, na jurídica, e na sua concepção securitária; a segunda, por sua vez, tem por objetivo contextualizar o interesse na história do seguro e nas várias teorias desenvolvidas sobre a matéria, que exercem influência definitiva sobre o papel do interesse em cada legislação.

O segundo capítulo dedica-se ao estudo das várias definições do interesse, apontando o conceito que prevaleceu no Direito brasileiro, qual seja, do interesse segurável como a relação entre um sujeito e um bem, ameaçada por um risco. Passa-se, então, ao estudo de cada um dos elementos que compõem tal definição. O estudo separado de cada elemento permite demonstrar como um mesmo bem pode ser objeto de diversos interesses, e o significado da exigência do interesse legítimo pelo Código Civil brasileiro.

O terceiro capítulo examina a natureza jurídica do interesse segurável. No Direito brasileiro, há relativo consenso sobre sua posição de objeto do contrato de seguro, mas na legislação estrangeira, o interesse ora é qualificado como elemento, ora como causa, ora como requisito de validade do contrato. Na segunda parte do trabalho (Capítulos 4, 5 e 6), estuda-se o interesse nos seguros de danos e seguros de pessoas. No seguro de dano, aborda-se, em capítulos separados, do interesse no seguro de coisa (Capítulo 4) e do interesse no seguro de responsabilidade civil (Capítulo 5), tendo em vista as peculiaridades de cada subespécie, em particular no que tange à diferença de tratamento legislativo acerca do valor segurável e das consequências da eventual insuficiência ou excesso de garantia.

Por fim, o sexto capítulo faz um estudo do interesse nos seguros de pessoas, tendo em vista que, aqui, não há aplicação do princípio indenitário, o que modifica a relação entre interesse e valor segurável apontada nos seguros de dano. Analisa-se, ainda, o eventual interesse de figurantes específicos do seguro de pessoas: o estipulante do seguro coletivo, o contratante, no seguro sobre a vida de outrem e o beneficiário, nos seguros de vida para o risco de morte. 
O objetivo desta pesquisa é estudar o interesse segurável e seus reflexos, de acordo com a legislação brasileira, em especial o Código Civil de 2002. Em vista da inexistência de obras específicas sobre o tema no País, recorreu-se, ao ao longo do trabalho, à legislação e experiência estrangeiras, bem como ao Projeto de Lei n. 3.555/2004. Neste último caso, considerou-se, para fins deste estudo, o Substitutivo aprovado na Comissão de Desenvolvimento Econômico, Indústria e Comércio, em julho de 2008.

Diante de tema tão complexo, a presente investigação apresenta-se como um grande desafio. Seu propósito, porém, não é esgotar o assunto ou dar respostas definitivas, mas sim suscitar o debate e contribuir de alguma maneira com o estudo de uma área tão fascinante como a do Direito do Seguro. 


\section{CAPÍTULO 1}

\section{NOÇÕES PRELIMINARES SOBRE O INTERESSE SEGURÁVEL}

\subsection{Etimologia e evolução do significado de interesse}

O termo interesse, apesar de ser usual e utilizado no cotidiano, tem muitos significados e sentidos, que se modificaram ao longo do tempo ${ }^{1}$.

Do ponto de vista etimológico, interesse é a substantivação do verbo latino interesse, que significa importar ${ }^{2}$. O prefixo inter possui a mesma acepção de entre ou no meio de e esse é o verbo ser.

Provost registra que, até o século XIII, o vocábulo interesse é associado à ideia de prejuízo, de dano. Segundo a autora, apesar do sentido apontado ter caído em desuso, foi com base nele que se criou o conceito de indenização (dommage-intérêts) ${ }^{3}$. A partir do século XV, o termo passa a ter um significado financeiro de ganho, de vantagem econômica auferida pelo credor no empréstimo; corresponde à usura dos romanos: "Usura est incrementum fenoris, ab usu aeris crediti nuncupata"4. Daí a palavra interest, que na língua inglesa até hoje significa juros, bem como o sentido de cobiça, avidez, que o termo expressa.

Somente após o século XV é que interesse adquire um significado mais amplo, além do sentido financeiro já explicitado, designando qualquer vantagem ou utilidade que alguém obtenha de um bem ou de uma situação ${ }^{5}$. No século XVIII, o termo assume um

\footnotetext{
${ }^{1}$ Sobre o assunto, Comparato adverte: "É sabido que as palavras mais usuais são as que contêm maior número de acepções. A usura do tempo, para os vocábulos de uso correntio, traduz-se paradoxalmente por uma multiplicação de sentidos. Mas essa proliferação de significados não se desenvolve sem lógica. Ela se assemelha à formação geológica de um terreno, mediante a superposição de sucessivas camadas: só um corte vertical revela o que a observação superficial é incapaz de descobrir." (COMPARATO, Fabio Konder. $O$ seguro de crédito. São Paulo: RT, 1968. p. 26).

${ }^{2}$ CUNHA, Antonio Geraldo da. Dicionário Etimológico Nova Fronteira da Língua Portuguesa. 2. ed. Rio de Janeiro: Nova Fronteira, 2001. p. 440-441.

3 'Dans sa première acception au XIIIe siècle, le mot 'intérêt' est synonyme de dommage, de prejudice. Bien que ce sens soit tombe aujourd' hui en désuétude, Il a permis de créer la terme de 'dommages-intérêts' qui son versés à la victime à titre de réparation" (PROVOST, Magalie. La notion d'intérêt d'assurance. Paris: LGDJ, Lextenso Éditions, 2009. p. 3).

${ }^{4}$ SILVA, De Plácido e. Vocabulário jurídico. 10. ed. Rio de Janeiro: Forense, 1987. p. 497.

${ }^{5}$ PROVOST, Magalie, op. cit., p. 4.
} 
sentido de importância, daquilo que chama a atenção, de curiosidade, passando a revelar também um sentimento mais altruísta de zelo em relação a alguém (preocupar-se com alguém, importar-se, demonstrar carinho) ou a algo (um livro, uma pintura, uma atividade que é de interesse ou que tem a qualidade de interessante $)^{6}$.

\subsubsection{Acepção jurídica de interesse}

Carnelutti inicia sua clássica obra Sistema di Diritto Processuale Civile com a seguinte frase: "Fundamental para o estudo do processo, assim como para o estudo do direito é o conceito de interesse" ${ }^{\text {7 }}$. O autor salienta que interesse se refere a uma situação (posizione), relativamente a um bem, favorável à satisfação de uma necessidade. Interesse, assim, é a relação existente entre o homem e o bem; nela, o sujeito do interesse é o homem e o objeto do interesse, o bem ${ }^{8}$.

Nesse mesmo sentido, De Plácido e Silva explica que interesse expressa "intimidade de relações entre a pessoa e as coisas" e que se manifesta pela "vantagem ou pela utilidade que se possa tirar das coisas, sejam direitos, fatos ou ações".

O interesse é a fonte, o substrato material do direito subjetivo, cuja definição clássica de Ihering ${ }^{10}$ é justamente "o interesse juridicamente protegido". Ainda que a definição de Ihering tenha sofrido críticas $^{11}$, há relativo consenso entre os doutrinadores

\footnotetext{
6 "Interest: early 15c., earlier interesse (late 14c.), from Anglo-Fr. interesse "what one has a legal concern in," from M.L. interesse "compensation for loss,' from L. interresse 'to concern, make a difference, be of importance', lit. 'to be between,' from inter- 'between' + esse 'to be.' Form influenced 15c. by O.Fr. interest 'damage,' from L. interest 'it is of importance, it makes a difference,' third person singular present of interesse. Financial sense of 'money paid for the use of money lent' (1520s) earlier was distinguished from usury (illegal under Church law) by being in reference to 'compensation due from a defaulting debtor.' Meaning 'curiosity' is first attested 1771. Interest group is attested from 1908; interest rate by 1959." (Disponível em: <http://www.etymonline.com/index.php?term=interest>. Acesso em: 10 set. 2010.)

7 "Fondamentale per lo studio del processo, anzi per lo studio del diritto, è il concetto di interesse" (CARNELUTTI, Francesco. Sistema di Diritto Processuale Civile. Padova: Cedam, 1936. v. I, p. 7).

${ }^{8}$ Ibidem, loc. cit.

${ }^{9}$ SILVA, De Plácido e. Vocabulário jurídico, p. 497.

${ }^{10}$ JHERING, Rudolf von. O espírito do Direito Romano III. Tradução de Rafael Benaion. Rio de Janeiro: Alba, 1943. p. 122.

${ }^{11}$ Nesse sentido: "Na conceituação de direito subjetivo não há unidade de vistas. R. Von Ihering definiu-o como o interesse juridicamente protegido. Windscheid, como o poder ou domínio de vontade conferido pela ordem jurídica. As duas concepções são incompletas, porque frisam um dos aspectos do direito subjetivo, pecando por unilateralismo. A de R. Von Ihering leva em conta apenas o fim, sem indicar os meios para alcançá-lo. A de Windscheid aponta os meios, mas silencia quanto ao fim. O direito subjetivo não é só poder da vontade, como não é apenas interesse, senão poder atribuído à vontade do sujeito para a satisfação dos
} 
acerca da estrita relação entre direito subjetivo e interesse. A esse propósito, comentando a definição de Ihering, José de Oliveira Ascensão explica:

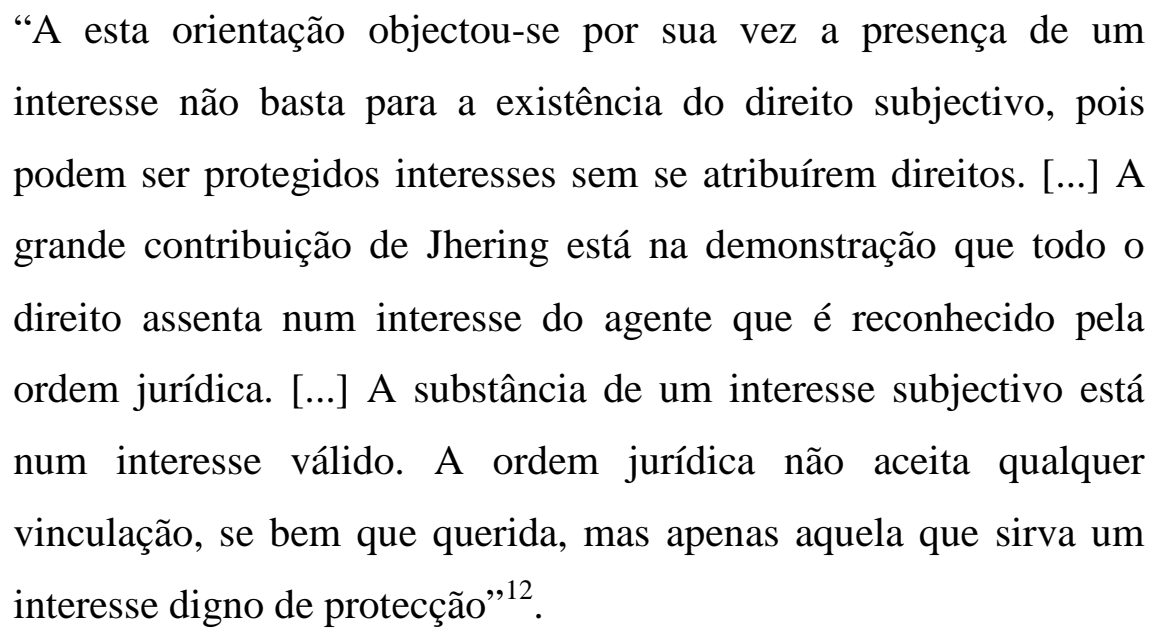

No processo civil, interesse e legitimidade integram as condições da ação (art. $3^{0}$ do CPC). O art. 76 do Código Civil de 1916, sem paralelo no Código atual, determinava que, "para propor, ou contestar uma ação, é necessário ter legítimo interesse econômico ou moral"13.

Conforme explica Pontes de Miranda, interesse aqui tem o significado de pretensão; é o interesse que se admita a demanda e que se profira sentença. Falta de interesse, portanto, é falta de necessidade de tutela jurídica ${ }^{14}$; não se confunde, pois, com o interesse que constitui o núcleo do direito subjetivo ${ }^{15}$.

seus próprios interesses protegidos legalmente" (GOMES, Orlando. Introdução ao Direito Civil. 6. ed. Rio de Janeiro: Forense, 1979. p. 129).

${ }^{12}$ ASCENSÃO, José de Oliveira. Direito Civil e Teoria Geral. Coimbra: Coimbra, 2002. v. III, p. 64-65.

${ }^{13}$ Clovis Bevilacqua, ao adjetivar interesse como legítimo, sofreu severa crítica de Pontes de Miranda, para quem legítimo trazia em si um prévio juízo sobre a decisão da demanda. Conclui o segundo autor que interesse legítimo nada mais é do que pretensão e acrescenta: "em vez de se ver a pretensão só do lado do direito, ver-se-ia do lado da vida (interesse) e do direito (legítimo). Porque 'legítimo' significa 'conforme o direito'. Assim, o interesse que se chamou de legítimo nada mais é do que 'o interesse que se admita a demanda e se profira a sentença"” (PONTES DE MIRANDA, Francisco Cavalcante. Comentários ao Código de Processo Civil. Rio de Janeiro: Forense, 1974. v. I, p. 155-156).

${ }^{14}$ Ibidem, p. 156.

${ }^{15}$ Nesse sentido: "Esse interesse, instrumental e secundário, não se confunde com o interesse que constitui o núcleo do direito subjetivo material. O interesse do credor, quando exige o pagamento de seu crédito, está em receber o que lhe é devido; mas ao propor ação para cobrar a importância desse pagamento, o interesse que condiciona o ius actionis diz respeito à prática de atos processuais para obter a tutela jurisdicional, pois não se examina, aí, se o crédito realmente existe, e, sim, se em face da pretensão formulada em juízo possibilidade tem o autor conseguir do Estado a prestação da tutela jurisdicional, por ser a sua pretensão objetivamente razoável. Inexistindo o crédito, falta ao credor, legítimo interesse em pretendê-lo do apontado devedor; inadmissível, para o caso levado a Juízo, a providência jurisdicional invocada, faltará legítimo interesse em propor a ação, porquanto inexiste pretensão objetivamente razoável que justifique a prestação 
Por essa razão é que, na qualidade de condição de ação, o primeiro significado de interesse é de necessidade, ou seja, tem interesse aquele que necessita do aparato estatal para obter a satisfação de um suposto direito. O segundo significado é de adequação, entendida como "a relação existente entre a situação lamentada pelo autor ao vir a juízo e o provimento jurisdicional concretamente solicitado"16.

\subsection{Interesse na concepção securitária}

O interesse expressa não somente uma relação de utilidade com um bem, mas também o intuito de preservação, de manutenção dessa mesma relação. Isto é, o interesse é o que impele um sujeito a constituir uma relação com determinado bem para obter determinada utilidade. Ao mesmo tempo, há um interesse na conservação desse bem até que sua utilidade se esgote.

Ao lado do interesse na constituição de uma relação, que se identifica com um juízo de utilidade de determinado bem para a satisfação de uma necessidade, há, portanto, o interesse na preservação dessa relação; afinal, o indivíduo que se encontra em determinada relação (lícita) com um bem tem o direito de gozar da utilidade que lhe é proporcionada. Daí por que se diz que o ordenamento jurídico tutela o interesse e não o bem ${ }^{17}$.

Dessa forma, no seguro, quando o ordenamento jurídico exige o interesse segurável, requer que entre o sujeito e o bem segurado exista um vínculo pelo qual, verificando-se o sinistro $^{18}$, entendido como a realização do acontecimento previsto no

jurisdicional requerida. Pas d'intérêt, pas d'action" (MARQUES, José Frederico. Manual de Direito Processual Civil. São Paulo: Saraiva, 1974. v.1, p. 158).

${ }^{16}$ CINTRA, Antonio Carlos de Araújo et al. Teoria geral do processo. 9. ed. São Paulo: Malheiros, 1993. p. 218.

${ }^{17}$ BUTTARO, Luca. L'interesse nell'assicurazione. Milano: Giuffrè, 1953. p. 9.

${ }^{18}$ Alvim esclarece que sinistro não necessariamente significa a ocorrência de um evento negativo, mas sim a realização do risco, independentemente de suas consequências: "A palavra sinistro, do latim sinister, significa adverso, inimigo, contrário, nocivo, funesto e infeliz. Durante muitos séculos, vigorou somente o seguro marítimo onde os riscos cobertos têm sempre um efeito nocivo e adverso para a navegação. A palavra sinistro exprimia, pois, com fidelidade a ocorrência dos fatos previstos. Todavia, com a expansão da atividade seguradora para os riscos terrestres e os de pessoa, surgiram coberturas de eventos que nem sempre importavam num acontecimento infeliz ou num infortúnio. O seguro de vida (sobrevivência) ou o de educação de um filho são exemplos de fatos auspiciosos para o segurado. O vocábulo adquiriu uma significação diferente na técnica do seguro. Sinistro é apenas a realização do acontecimento previsto no contrato, independentemente de suas consequiências. Enquanto não ocorre, o risco é um evento incerto, seja quanto à sua realização, seja quanto ao tempo de sua ocorrência. Quando deixa de ser incerteza para 
contrato de seguro, há uma consequência desvantajosa para o segurado. O sinistro constitui lesão de um interesse porque turba a relação entre o sujeito e o bem e reduz ou anula a utilidade que esse bem poderia produzir ao sujeito ${ }^{19}$. Em sua concepção securitária, portanto, interesse exprime uma intenção de preservação de uma relação entre o sujeito e o bem, passível de ser afetada por um evento futuro e de data incerta, que independa da vontade do sujeito - o risco.

O interesse segurável surge, assim, como um critério de distinção entre o seguro e a aposta, a fim de que a realização do risco não seja desejada pelo titular do interesse. Provost $^{20}$ relata que dois fatores contribuíram para a construção do interesse em sua concepção securitária. Em primeiro lugar, o fator econômico, a fim de que a indenização securitária não seja utilizada como meio de enriquecimento de especuladores; em segundo, o fator social, com o propósito de que o seguro seja utilizado apenas por aqueles que almejam se proteger contra riscos indesejados a que os bens - materiais e imateriais, incluindo a vida - estão sujeitos.

\subsection{Antecedentes históricos: as primeiras legislações sobre "interesse segurável"}

O seguro se desenvolveu com as explorações marítimas e por vários séculos se restringiu aos riscos do mar. O século XVI foi marcado pela ampliação das rotas marítimas, com a descoberta do novo caminho para as Índias e do continente americano. $\mathrm{O}$ incremento do risco decorrente das grandes navegações impactou o seguro, impulsionando seu desenvolvimento ${ }^{21}$.

transformar-se numa realidade fática muda de nome; passa a denominar-se sinistro" (ALVIM, Pedro. $O$ contrato de seguro. 3. ed. Rio de Janeiro Forense, 1999. p. 393-394).

${ }^{19}$ BUTTARO, Luca. L'interesse nell'assicurazione, p. 10.

20 "Deux facteurs ont contribué à l'elaboration de l'intérêt d'assurance. D'une part, un facteur économique: l'assureur n'a pas à enrichir un simples parier. Il faut donc supprimer la confusion opérée entre assurance et le pari afin de que l'assurer ne verse pas une prestation d'assurance à celui que spécule sur le retour d'un navire ou sur la vie d'un homme cèlébre.

D'autre part, un facteur social: il est indispensable de distinguer l'assurance du pari pour éviter les abus. L'assurance a pour unique fonction d'accorder une sécurité à celui qui souhaite se protéger contre les aléas de la vie. D'où la necessitè d'un critère de distinction entre l'assurance et le pari." (PROVOST, Magalie. La notion d'intérêt d'assurance, p. 42).

${ }^{21}$ ALVIM, Pedro, op. cit., p. 33. 
As Ordenanças de Barcelona (1484), Burgos (1538) e Sevilha (1556) são exemplos das primeiras legislações que tratavam do interesse segurável, ainda exclusivamente em matéria de seguro marítimo ${ }^{22}$. Foi, no entanto, na Alemanha que a teoria se desenvolveu e passou a ser aplicada também para os seguros terrestres, em razão dos incêndios que devastaram Hamburgo em 1606, 1626 e $1676^{23}$.

Ainda assim, no século XVII, contratos de apostas eram considerados válidos como qualquer outro tipo de contrato. Na Inglaterra, por exemplo, os casos de apostas travestidos em contratos de seguro não eram questionados pelos Tribunais. Uma pessoa podia, assim, segurar uma embarcação ou uma carga, sem a necessidade de demonstrar um interesse na sua preservação e um dano decorrente de sua perda, fazendo jus ao recebimento de indenização em caso de naufrágio ou avaria. Eram as chamadas apólices no interest ${ }^{24}$.

O primeiro ato legislativo promulgado para mudar essa realidade foi o Marine Insurance Act $1745^{25}$, que considerava nulas as apólices de seguro marítimo expedidas sem interesse. $\mathrm{O}$ objetivo era justamente impedir que o seguro fosse um incentivo para a destruição do bem segurado ${ }^{26}$.

A prática de emissão de apólices de seguro sobre a vida de pessoas públicas, ou ainda sobre parentes distantes ou meros conhecidos, todavia, permanecia, transformando o contrato de seguro em uma verdadeira aposta sobre a vida. Decorridos trinta anos do Marine Insurance Act 1745, promulgou-se o Life Assurance Act $1774^{27}$, pelo qual eram considerados nulos os contratos de seguro emitidos sem interesse. Em seguida, veio o

\footnotetext{
${ }^{22}$ Nesse sentido: MORANDI, Juan Carlos Felix. Estudios de derecho de seguros. Buenos Aires: Pannedille, 1971. p. 25.

${ }^{23}$ PROVOST, Magalie. La notion d'intérêt d'assurance, p. 74.

${ }^{24}$ DOBBYN, John. Insurance Law in a nutshell. $3^{\text {rd }}$ reprint. St. Paul, Minn.: West Publishing Co., 1994. p. 44.

${ }^{25}$ Consoante o preâmbulo do Marine Insurance Act 1745: "It hath been found by experience, that the making of insurances, interest or no interest, or without further proof of interest than the policy, hath been productive of many pernicious practices, whereby great number of ships, with their cargos, have been fraudulent lost or destroyed".

${ }^{26}$ É o que se chama de moral hazard. Nesse sentido: Insurance Contract Law. Issues Paper 4 - Insurable Interest. p. 5. Disponível em: <www.lawcom.gov.uk/.../Insurance_Contract_Law_Issues_Paper_4.pdf>. Acesso em: 15 ago. 2010.

27 "Life Assurance Act 1774:

(Preamble) Whereas it hath been found by experience that the making insurances on lives or other events wherein the assured shall have no interest hath introduced a mischievous kind of gaming.

1. From and after the passing of this Act no insurance shall be made by any person or persons, bodies politick or corporate, on the life or lives of any person, or persons, or on any other event or events whatsoever, wherein the person or persons for whose use, benefit, or on whose account such policy or policies shall be made, shall have no interest, or by way of gaming or wagering; and every assurance made contrary to the true intent and meaning hereof shall be null and void to all intents and purposes whatsoever."
} 
Insurance Marine Act 1788; nele, passou-se a exigir que o nome da pessoa interessada constasse da apólice, para facilitar a verificação do interesse.

Por fim, com o propósito de banir o contrato de aposta, seja no formato de seguro, seja de qualquer outra forma, foi promulgado o Gaming Act de $1845^{28}$. Referido ato considerava nula qualquer aposta, determinando que nenhuma ação poderia ser proposta para o recebimento de valores ou prêmios supostamente devidos a esse título.

Com a promulgação do Gaming Act, somente os contratos de seguro em que fosse demonstrada a existência de um interesse segurável eram tidos como válidos. O interesse segurável, portanto, é o elemento que distingue o contrato de seguro da aposta. No primeiro caso, o segurado tem interesse na preservação do bem, pois a sua perda lhe causa um dano; no segundo, não há interesse de preservação, uma vez que a perda do bem é fonte de lucro.

\subsection{A diferença de tratamento do "interesse segurável" nos seguros de danos e de pessoas}

Nos dias atuais, muitos países, destacando-se a França, a Itália e a Alemanha, limitam a aplicação do interesse segurável ao seguro de danos. Segundo Provost ${ }^{29}$, as razões históricas para isso são, de um lado, conceituais, na medida em que a teoria do interesse não se adaptou à teoria do seguro de pessoas e, de outro, formais, no intuito de simplificar a contratação.

A classificação dos seguros entre seguros de dano e seguros de pessoas é de suma importância. Os seguros de dano e os de pessoas possuem estruturação técnica e objetivos

\footnotetext{
${ }^{28}$ O Ato em referência previa que: "All contracts or agreements, whether by parole or in writing, by way of gaming or wagering, shall be null and void; and no suit shall be brought or maintained in any court of law and equity for recovering any sum of money or valuable thing alleged to be won upon any wager, or which shall have been deposited in the hands of any person to abide the event on which any wager shall have been made: Provided always, that this enactment shall not be deemed to apply to any subscription or contribution, or agreement to subscribe or contribute, for or towards any plate, prize, or sum of money to be awarded to the winner or winners of any lawful game, sport, pastime, or exercise.".

${ }^{29}$ PROVOST, Magalie. La notion d'intérêt d'assurance, p. 73.
} 
$\operatorname{distintos}^{30}$, o que justifica o Código Civil brasileiro, a exemplo da maioria das legislações, ter previsto, no Capítulo XV, intitulado Do Seguro, uma seção contendo as disposições gerais (Seção I - art. 757 ao art. 777) e duas seções distintas com as regras específicas de cada modalidade $^{31}$ (Seção II - Do seguro de dano, arts. 778 a 788, e Seção III - Do seguro de pessoas, arts. 789 a 802).

A diferença essencial entre ambos é a natureza do valor a ser recebido em caso de sinistro. Nos seguros de danos, tem aplicação o princípio indenitário, segundo o qual a indenização deve corresponder ao efetivo prejuízo sofrido pelo segurado, sendo vedado que obtenha um lucro com a ocorrência do evento danoso. Já nos seguros de pessoas, o capital segurado é estipulado livremente pelo segurado, sem a exigência de uma correspondência com o dano. Por isso, na Inglaterra, por exemplo, os seguros que se submetem ao princípio indenitário são chamados de indemnity insurance (seguros de indenização), ao passo que os seguros de valor fixo são denominados non-indemnity insurance (seguros de não indenização) ou, ainda, contingency or valued policies (apólices de valor ou contingência) ${ }^{32}$.

Conforme observado, o interesse segurável tem sua origem nos riscos marítimos, sendo posteriormente aplicado nos seguros de coisas ${ }^{33}$, para riscos tanto marítimos como terrestres $^{34}$. Nessa modalidade, são três as funções do interesse: 1) garantir o interesse do segurado na conservação do bem; 2) garantir que a realização do risco não signifique uma vantagem para o segurado, limitando a indenização ao valor do interesse; e 3) apontar quem é o titular do interesse e, portanto, o credor da indenização securitária.

\footnotetext{
${ }^{30}$ Cf. ALVIM, Pedro. O contrato de seguro, p. 78.

31 Nesse sentido, Comparato: "Seguindo, portanto, a orientação consagrada nos melhores modelos legislativos (leis alemã e suíça de 1908, lei francesa de 1930, Código Civil Italiano), cuidamos de separar em seções distintas as regras específicas dos seguros de dano e dos seguros de pessoas, após o enunciado das disposições gerais" (COMPARATO, Fabio Konder. Substitutivo ao capítulo referente ao contrato de seguro no anteprojeto de Código Civil. Revista de Direito Mercantil, ano XI, n. 5, p. 143-152, 1972, p. 147).

${ }^{32}$ Conforme THE LAW COMISSION AND THE SCOTTISH LAW COMISSION. Insurance contract law. Issues Paper 4. Insurable Interest, 14.01.2008. p. i. Disponível em: <www.lawcom.gov.uk/.../ Insurance_Contract_Law_Issues_Paper_4.pdf>. Acesso em: 15 ago. 2010.

${ }^{33}$ A denominação seguro de coisa é anterior à atual seguro de dano. A primeira abrange os seguros de danos materiais (incêndio, transportes, automóvel), excluindo os seguros de responsabilidade civil (de perda de patrimônio) que são posteriores ao passo que a segunda engloba ambas as modalidades e é atualmente adotada pela maioria dos doutrinadores. Nesse sentido: ALVIM, Pedro. O contrato de seguro, p. 79.

${ }^{34}$ A classificação dos seguros entre marítimos e terrestres se deve à própria origem do seguro nos riscos marítimos, ramo que reinou sozinho por vários séculos e que deu origem às primeiras legislações. Os ramos chamados então de terrestres vieram posteriormente, com disciplina jurídica diferente dos primeiros. Ambos, porém, são seguros de dano (cf. ibidem, p. 91).
} 
A teoria retromencionada, construída com base no seguro de dano, possui algumas limitações ao ser aplicada ao seguro de pessoas. No seguro de dano, o interesse é a medida da indenização, ao passo que no seguro de pessoas, a vida humana não é suscetível de avaliação pecuniária. E se, no seguro de danos, o credor da indenização securitária é aquele que sofre o prejuízo, no seguro de pessoas, não há como demonstrar o dano patrimonial sofrido pelo beneficiário ${ }^{35}$. No seguro de danos, exige-se, em regra, um interesse de natureza econômica; no seguro de pessoas, o interesse pode resultar de uma relação afetiva. Não bastassem as diferenças apontadas, historicamente, o seguro de pessoas suscitou intenso debate envolvendo a questão de a pessoa humana poder ou não ser objeto de um seguro, tanto do ponto de vista de sua licitude como de sua moralidade ${ }^{36}$.

O seguro de vida $^{37}$ teve origem na Inglaterra, no século XVIII, fruto do desenvolvimento comercial, técnico e jurídico ${ }^{38}$ que propiciou a constituição de empresas de seguro e a elaboração das primeiras tábuas de mortalidade ${ }^{39}$. Várias seguradoras foram criadas, mas não havia vidas suficientes para formar o capital segurado necessário.

Na primeira metade do século XIX, com o desenvolvimento da indústria e o aumento da disponibilidade de capital, o seguro de vida passou a ser visto como um negócio rentável e útil para a sociedade. Em países como Inglaterra e França, o interesse segurável era exigido tanto nos seguros de danos como nos seguros de pessoas ${ }^{40}$.

Após a Segunda Guerra Mundial, os países mais devastados, como França, Itália e Alemanha, decidiram facilitar a contratação do seguro de vida. Na França, houve intensa

\footnotetext{
${ }^{35}$ PROVOST, Magalie. La notion d'intérêt d'assurance, p. 74-75.

${ }^{36}$ Ibidem, p. 75.

37 Os seguros de pessoas eram inicialmente chamados de seguros de vida, já que essa foi a primeira modalidade de contratação. Mezzomo registra a diferença existente entre os seguros de vida e os de pessoas: "se é certo que todo seguro de vida é pessoal, nem todo seguro pessoal é de vida" (MEZZOMO, Marcelo Colombelli. Breves apontamentos sobre o contrato de seguro. Âmbito Jurídico, 25 nov. 2010. Disponível em: <hwww.ambito-juridico.com.br/site/index.php?n_link=revista_artigos_leitura\&artigo_id=4687>. Acesso em: 25 nov. 2010.) E prossegue o estudioso, salientando que os seguros pessoais abrangem a generalidade dos seguros, cobrindo perdas e danos ou responsabilidades sobre pessoas, bens ou obrigações. Por último, lembra que os seguros de vida se dividem em seguros de vida e seguros de sobrevivência. "A diferença entre os seguros de vida propriamente ditos e de sobrevivência está em que no primeiro a morte do segurado determina o benefício a terceiros ao passo que no seguro de sobrevivência, a liquidação se dá em vida do segurado, a termo certo ou condição, incluindo-se seguros totais, para custeios de estudos etc." (ibidem).

${ }^{38}$ MORANDI, Juan Carlos Felix. Estudios de derecho de seguros, p. 30-31.

${ }^{39}$ A primeira tábua de mortalidade aparece em 1693, elaborada pelo inglês Edmond Halley. Nessa época, Halley publica no Philosophal Transactions da Royal Society of London sua Breslau table of mortality, pautando-se no número de nascimentos e óbitos da cidade de Breslau. Essa tábua foi logo apropriada pelos seguradores "para fixar o quantum das anuidades vitalícias dos seguros de vida e ampliar o caráter científicoformal que pretendiam dar a sua atividade" (MILONE, Giuseppe. Estatística geral e aplicada. São Paulo: Pioneira Thomson Learning, 2004. p. 348).

${ }^{40}$ PROVOST, Magalie, op. cit., p. 75.
} 
propaganda dos benefícios do seguro de vida, com a publicação de livros, artigos e a realização de conferências. A contratação foi facilitada pela inexistência de exigência de um interesse segurável, bastando o consentimento escrito do segurado, nos casos em que o seguro era contratado por um terceiro ${ }^{41}$. Em face de sua aplicação exclusiva ao seguro de dano, em alguns países, essa modalidade é chamada também de seguro de interesses ${ }^{42}$.

\subsection{As várias teorias sobre o contrato de seguro: a busca por um conceito unitário aplicável ao seguro de danos e de pessoas}

Além das raízes históricas, a concepção securitária de interesse e sua aplicação ou não ao seguro de pessoas variam de acordo com as diversas teorias existentes acerca do contrato de seguro e de sua definição.

\subsubsection{A Teoria Indenitária Tradicional}

A primeira teoria sobre o contrato de seguro, ao adquirir uma concepção jurídica diversa da de outros contratos, denomina-se Teoria Indenitária Tradicional e foi concebida por tratadistas franceses ${ }^{43}$ e alemães ${ }^{44}$ no final do século $\mathrm{XIX}^{45}$.

\footnotetext{
${ }^{41}$ MORANDI, Juan Carlos Felix. Estudios de derecho de seguros, p. 31; PROVOST, Magalie. La notion d'intérêt d'assurance, p. 77.

${ }^{42}$ Nesse sentido: "El carácter ressarcitório del seguro de daños o intereses es indiscutible" (HALPERIN, Isaac. El contrato de seguro. Buenos Aires: Tipografica, 1946. p. 17).

${ }^{43}$ MORANDI, Juan Carlos Felix (op. cit., p. 88) cita ALAUZET, Isidore. Traité générale des assurances. Paris: Cosse, 1844. t. II, p. 550; LEFORT, J. Traité théorique et pratique du contrat d'assurances sur la vie. Paris: Thorin \& Fils, 1893-1900. t. I, p. 177; e HERBAULT, Paul. Traité des assurances sur la vie. Paris: Marescq Aine, 1877. p. 54.

${ }^{44}$ Morandi (op. cit., p. 88) cita Lewis Goldschmitdt e Staudinger Gerhard, sem se referir, porém, às obras dos respectivos autores. Reporta-se também a WAGNER, A. Le assicurazioni. Biblioteca dell'Economista, Torino, serie III, t. XIII, n. 188, 1891. p. 801 et seq.

${ }^{45}$ MORANDI, Juan Carlos Felix, op. cit., p. 88.
} 
A concepção do seguro como um contrato de indenização foi acolhida por algumas legislações, a exemplo do Código Civil de $1916^{46}$, que definia o seguro, no art. 1.432, como "um contrato em que o segurador se obriga, mediante o pagamento de um prêmio, a indenizar o segurado das perdas ou danos que sofrer em conseqüência de certos eventos fortuitos ou de força maior".

Ocorre que o dano presente no seguro de coisas não existe necessariamente no seguro de pessoas, a exemplo do seguro de sobrevivência, em que o sinistro se dá justamente pela continuidade da vida do segurado após determinada idade ${ }^{47}$. E mesmo que o dano esteja configurado, não é passível de constituir a medida da indenização securitária, pois não guarda relação com um efetivo prejuízo sofrido.

Diante das incongruências apontadas, a Teoria Indenitária, na tentativa de se aplicar ao seguro de pessoas, advogava que, como a vida de uma pessoa tem valor inestimável, o que se indeniza é um dano moral: o seguro não recai sobre a pessoa e, sim, sobre o capital previsto no contrato, consistindo o sinistro em uma interrupção de um processo de cumulação $^{48}$.

Esse posicionamento, no entanto, não se sustentava, pois a indenização securitária não guardava relação com os prêmios pagos, principalmente nos casos em que a morte do segurado era prematura - e, portanto, a cumulação de prêmios era muito inferior ao capital segurado - ou, ao contrário, quando o segurado era longevo - e o acúmulo de prêmio superava a indenização securitária prevista no contrato.

Também não se sustentava a tentativa de definir o dano no seguro de pessoas como um dano moral, pois a soma segurada não guarda correlação com a ideia de dano ${ }^{49}$.

\footnotetext{
${ }^{46}$ Conforme ALVIM, Pedro. O contrato de seguro, p. 95.

${ }^{47}$ Nesse sentido: "No tocante a outros fatos da vida humana, não há pensar-se, sequer, em dano, como se o seguro é para o evento de casamento, ou de nascimento de filho. Não há perda patrimonial que se tenha que reparar. A atitude dos que afastam que aí se trate de seguro é de repelir-se, mesmo se há alusão a contrato misto de empréstimo e de seguro" (PONTES DE MIRANDA, Francisco Cavalcante. Tratado de Direito Privado. Rio de Janeiro: Borsoi, 1964. t. XLV, p. 273).

${ }^{48}$ MORANDI, Juan Carlos Felix. Estudios de derecho de seguros, p. 89.

${ }^{49}$ Cf. Pontes de Miranda: "Assim, a teoria da indenização assecurativa tem de ser posta de lado, não só por ser obsoleta como por ser fora dos fatos da vida jurídica. Pode haver e pode não haver indenização." (PONTES DE MIRANDA, Francisco Cavalcante, op. cit., p. 273).
} 


\subsubsection{A Teoria da Necessidade}

A Teoria da Necessidade, criada pelo economista italiano Gobbi ${ }^{50}$ no final do século XIX, contava com um número notável de seguidores, destacando-se os doutrinadores alemães Manes ${ }^{51}{\text { e } \text { Bruck }^{52} \text { e, posteriormente, o também italiano Viterbo }}^{53}$.

Diante da insuficiência da Teoria Indenitária, o conceito de dano é substituído pelo de necessidade, assim uma necessidade nasce cada vez que um risco, concretizando-se, modifica em senso desfavorável a relação entre as necessidades de uma pessoa e os meios que essa tem à sua disposição para satisfazê-las ${ }^{54}$. O risco vem definido, por consequência, como "uma eventualidade que, verificando-se, modifica em senso desfavorável a relação entre as necessidades e os meios de satisfazê-las" ${ }^{25}$, ou, mais brevemente, como uma eventualidade que provoca uma necessidade. De acordo com a Teoria da Necessidade, portanto, a função essencial do seguro é "satisfazer uma necessidade eventual do beneficiário" ${ }^{, 56}$, colocando uma soma em dinheiro à disposição do segurado.

Ao apresentar um conceito de necessidade mais lato do que o de dano, a Teoria da Necessidade mostrou-se mais adequada aos seguros de vida, em especial aos seguros de sobrevivência. A teoria em comento desenvolve o conceito de risco, presente em qualquer tipo de seguro. Com a verificação do risco, surge para o segurado uma necessidade que pode ser verificada de maneira aproximada (in abstracto) ou exata (in concreto) ${ }^{57}$.

A Teoria da Necessidade foi responsável por precisar as características do risco e desenvolver a noção de interesse segurável, estabelecendo diferença entre o seguro do jogo e o da aposta. Celebrar um contrato de seguro significa, assim, prevenir-se em relação a um risco preexistente e o dano decorrente de sua realização. Mas, para que o dano exista, é preciso que o segurado, beneficiário do seguro, não tenha interesse em sua realização; caso contrário, a verificação do risco seria convertida em lucro.

\footnotetext{
${ }^{50}$ Cf. PROVOST, Magalie. La notion d'intérêt d'assurance, p. 222.

${ }^{51}$ MANES, Alfredo. Tratado de seguro. Teoria general del seguro. Trad. da 4. ed. alemã por Femim Soto. Madrid: Logos, 1930. p. 9. In: FERRARINI, Sergio. L'interesse nell'assicurazione. Pisa: Nistri-Lischi, 1935.

52 BRUCK, W. Das Privatversicherungsrecht. Mannheim-Berlin-Leipzig, 1930. p. 52 et seq. In: FERRARINI, Sergio, op. cit.

${ }^{53}$ Cf. ASCARELLI, Tullio. O conceito unitário do contrato de seguro. In: Problemas das sociedades anônimas e Direito Comparado. São Paulo: Saraiva, 1945. p. 205.

${ }^{54}$ Cf. MORANDI, Juan Carlos Felix. Estudios de derecho de seguros, p. 91.

${ }^{55}$ Ibidem, loc. cit.

${ }^{56}$ ASCARELLI, Tullio, op. cit., p. 205.

${ }^{57}$ MORANDI, Juan Carlos Felix, op. cit., loc. cit.
} 
A Teoria da Necessidade conclui, assim, que o seguro não existe sem um interesse segurável, por ser indispensável que o sinistro constitua um evento danoso para o beneficiário da indenização. Emerge ainda da noção de interesse segurável o caráter de cooperação próprio do contrato de seguro, tendo em vista que o interesse de inocorrência do sinistro, bem como de limitar suas consequências, é tanto do segurado como do segurador $^{58}$.

A despeito de todos os méritos da teoria em análise, ela fracassou na construcão de um conceito unitário para o seguro de dano e de pessoas. Isso porque a necessidade, no seguro de pessoas, é subjetiva, estimada unicamente pelo segurado ou pelo estipulante no momento da conclusão do contrato ${ }^{59}$. No seguro de dano, todavia, é possível determinar a necessidade por meio de dados objetivos. Essa determinação pode ser feita também no momento da conclusão do contrato, mas a ela não se limita. A necessidade será apurada no momento da concretização do risco, mais especificamente, mediante os efeitos produzidos por essa concretização na relação existente entre o segurado e o bem ${ }^{60}$.

Nos seguros de dano, o beneficiário da indenização, de quem se exige a demonstração do interesse segurável, em rigor coincide com o segurado-estipulante. No seguro de vida, porém, o beneficiário não coincide com o contratante e não lhe são exigidas a prova de um dano e a presença do interesse segurável no momento da contratação.

Consoante assinalado, essa discrepância contribuiu para que muitas legislações limitassem a aplicação do interesse segurável ao seguro de dano. Diversos autores, como Garrigues $^{61}$ e Ferrarini ${ }^{62}$, por exemplo, preconizam que o interesse é um conceito

\footnotetext{
${ }^{58}$ MORANDI, Juan Carlos Felix. Estudios de derecho de seguros, p. 92; e ASCARELLI, Tullio. O conceito unitário do contrato de seguro. In: Problemas das sociedades anônimas e Direito Comparado, p. 206.

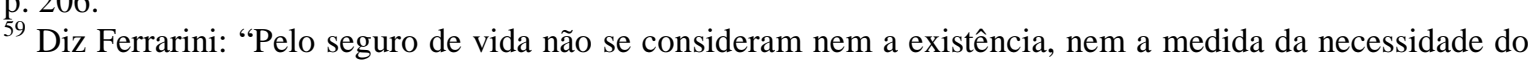
segurado: o segurador deve a sua prestação pelo só fato de tornar-se verdadeiro o risco." (FERRARINI, Sergio. L'interesse nell'assicurazione, p. 11-12). Para os defensores de que o conceito de interesse somente existe no seguro de dano, o interesse no seguro de vida aparece por razões de ordem pública e equiparado à autorização do terceiro para a realização de um seguro de vida. O Projeto do Código de Comércio dispõe no art. 481: "a asseguração contratada no caso de morte de um terceiro não é válida, se o estipulante não tenha algum interesse na existência desse, ou seja, se o terceiro não der por escrito o próprio consenso à conclusão do contrato".

${ }^{60}$ Ibidem, p. 6.

${ }^{61}$ "Nos proponemos dar algunas ideas sobre el interés, tema éste que tiene su marco própio en el seguro contra daños, dado que el interés es un concepto inseparable del de daño patrimonial. Por ello, las leyes, como veremos, mencionan el interés solo al tratar de esta clase de seguro. Generalizar a todos los seguros la doctrina del interés sería tanto como adherirse a la "teoría indemnitaria" del contrato de seguro y esta no es nuestra posición" (GARRIGUES, Joaquim. Algunas ideas sobre el interés en el seguro contra daños. In:
} 
inseparável do seguro patrimonial. No Brasil, Alvim ${ }^{63}$ também sustenta que o interesse segurável somente é compreensível nos seguros de dano; isso porque, nos seguros de pessoa, acaba se confundindo com os motivos que levam o segurado a contratar, não integrando a estrutura do contrato.

\title{
1.5.3 A Teoria da Empresa
}

Vivante desenvolveu a Teoria da Empresa, que aponta como elemento de unicidade de todos os contratos de seguro o fato de que,

\begin{abstract}
"[...] em todos os seus ramos, o seguro é exercido pelo segurador, sistematicamente, com fundamento no cálculo de probabilidades, de modo a, considerada a massa dos contratos, desaparecer o caráter aleatório, próprio de cada contrato visto isoladamente, e surgir a possibilidade da previsão da ocorrência dos sinistros, baseada naquele cálculo" ${ }^{\circ 4}$.
\end{abstract}

A teoria em foco ressalta a importância da mutualidade de qualquer seguro, pois somente por meio de um grande número de contratos o seguro poderá exercer sua função social de repartir o risco por uma massa de segurados. Por reconhecer a importância desse princípio, muitas legislações - inclusive a brasileira, no Código Civil de $2002^{65}$ - exigem

\footnotetext{
ASSOCIAZIONE INTERNATIONALE DI DIRITTO DELLE ASSICURAZIONI - AIDA. Studi in onore di Antigono Donati. Roma: Edizioni Della Rivista Assicurazioni, 1970. v. I, p. 173).

62 "Appare ora chiaramente como il concetto di interesse sai proprio ed esclusivo delle assicurazioni contro i danni. La definizione stessa di interesse, quale rapporto di persona e cosa, esclude la possibilita di applicare il concetto nell'assicurazione vita" (FERRARINI, Sergio. L'interesse nell'assicurazione, p. 11).

63 "Esse interesse é compreensível nos seguros de dano. Mas nos de pessoa, quando o segurado faz seu próprio seguro, como é comum, a noção de interesse segurável se confunde com a de foro íntimo, isto é, com os motivos que levaram o segurado a contratar.

Eis por que Vivante equipara essa teoria à da necessidade eventual e a combate sobre o fundamento de que esses motivos não penetram a estrutura do contrato. O juiz não pode intrometer-se no seu exame para decretar a nulidade. Não constitui, pois, um elemento essencial." (ALVIM, Pedro. O contrato de seguro, p. 101).

${ }^{64}$ Cf. ASCARELLI, Tullio. O conceito unitário do contrato de seguro. In: Problemas das sociedades anônimas e Direito Comparado, p. 209.

${ }^{65}$ Parágrafo único do art. 757: "Somente pode ser parte, no contrato de seguro, como segurador, entidade para tal fim legalmente autorizada".
} 
que a atividade securitária somente seja exercida por entidades regularmente constituídas e autorizadas para esse fim, subordinadas às regras rígidas de constituição de capital.

Ainda assim, Ascarelli ${ }^{66}$ ressalta que a Teoria da Empresa também não é suficiente para a elaboração de uma teoria unitária, pois o pressuposto técnico para que a seguradora possa realizar a função que lhe é própria não integra a causa do contrato. Essa teoria também foi rejeitada por Pontes de Miranda ${ }^{67}$, por ter o defeito de buscar nos meios técnicos o elemento com que se explicaria o contrato.

\subsubsection{A Nova Teoria Indenitária}

Na busca contínua de um denominador comum no seguro de dano e de pessoas, é elaborada a Nova Teoria Indenitária, tendo como principal defensor Donati ${ }^{68}$, seguido por Ascarelli $^{69}$, Morandi ${ }^{70}$ e Buttaro ${ }^{71}$. No Brasil, essa teoria é defendida por Comparato, no que tange à doutrina do interesse segurável ${ }^{72}$. A base da Nova Teoria Indenitária, conforme explica Mello Franco ${ }^{73}$, é o trinômio presente em qualquer contrato de seguro: interesse, necessidade e dano.

De acordo com a Nova Teoria Indenitária, o evento que provoca uma necessidade ocasiona um dano. Necessidade econômica em sentido objetivo e dano são, assim, conceitos coincidentes, entendendo-se por dano toda diminuição de patrimônio, seja em

\footnotetext{
66 "Resumindo, poder-se-ia dizer que a tese de Vivante, como a da doutrina francesa, indica a base técnica da indústria seguradora, não, porém, a característica jurídica do contrato" (ASCARELLI, Tullio. O conceito unitário do contrato de seguro. In:___. Problemas das sociedades anônimas e Direito Comparado, p. 212).

${ }^{67}$ PONTES DE MIRANDA, Francisco Cavalcante. Tratado de Direito Privado, t. XLV, p. 273.

${ }^{68}$ DONATI, Antigono. Trattato del Diritto delle Assicurazioni Private. Giuffrè: Milano, 1952. t. II, p. 18-27.

${ }^{69}$ ASCARELLI, Tullio, op. cit., p. 213.

${ }^{70}$ MORANDI, Juan Carlos Felix. Estudios de derecho de seguros, p. 96.

${ }^{71}$ BUTTARO, Luca. L'interesse nell'assicurazione.

72 O autor não reconhece o "dano" como elemento presente em ambas as espécies de seguro, tanto que não utiliza o vocábulo "indenização" na seção relativa ao "seguro de pessoas". Por isso, ao referir-se à Nova Teoria Indenitária, alude apenas ao "interesse": Esta nos parece a mais aceitável 'concepção unitária' do contrato de seguro, aceitando-se a comunhão do gênero economico do interesse, tanto nos seguros de dano, como nos seguros de pessoas, mas marcando-se a sua diferença específica." (COMPARATO, Fabio Konder. O seguro de crédito, p. 25, nota de rodapé n. 23).

${ }^{73}$ FRANCO, Vera Helena de Mello. Contratos no Direito Privado: direito civil e empresarial. São Paulo: Revista dos Tribunais, 2009. p. 281.
} 
razão de sua redução (dano emergente) ou da perda de um aumento patrimonial esperado (lucros cessantes ou benefício esperado). Em rigor, o dano deve ser efetivo e sua avaliação concreta; todavia, ainda que seja difícil ou mesmo impossível a valoração do dano, não se exclui que essa valoração seja feita de modo estimado pelas partes ou pela lei.

Para a Nova Teoria Indenitária, portanto, o seguro é sempre um contrato de indenização, sendo essa a sua função essencial; a diferença é que, no seguro de pessoas, a indenização é preventivamente determinada, ao passo que no seguro de danos a indenização é passível de uma valoração concreta.

Da mesma forma, presente tanto no seguro de dano como no seguro de pessoa, encontra-se o interesse segurável, elemento central do contrato, sem o qual deixa de ser um contrato de seguro. Segundo Ascarelli ${ }^{74}$, a ausência de um interesse contrário à ocorrência do sinistro conduz à possibilidade de provocação do dano, o que dificulta a possibilidade técnica da operação baseada no cálculo de probabilidades. É, ademais, o interesse que indica a função econômica do seguro de reparar um dano, distinguindo-o do jogo ou da aposta.

Conforme explica Morandi ${ }^{75}$, o pressuposto dogmático da Nova Teoria Indenitária são as três classes de dano: dano emergente, lucro cessante e benefício esperado. Diverso do dano emergente, que tem um grau de certeza, os lucros cessantes e o benefício esperado se fundamentam em critérios de probabilidade, de maneira que, quanto mais tênue o nexo de causalidade, maior a dificuldade de sua prova e de sua avaliação concreta, mostrando-se necessária uma forma diversa de avaliação, abstrata e preventiva. Ascarelli ${ }^{76}$ ressalta que essa avaliação diversa não contraria, de modo nenhum, o conceito de ressarcimento do dano. O mecanismo é até mesmo reconhecido pelo direito, como se dá na cláusula penal.

Rechaça-se, pois, o argumento de que a inestimabilidade da vida humana impeça a sua valoração no terreno patrimonial. Se assim fosse, conforme Ascarelli ${ }^{77}$, não seria possível fixar a indenização cabível nos casos de homicídio ou de lesão corporal. Já no seguro de sobrevivência, o evento danoso é a velhice e não a morte. Não se nega as consequências danosas da velhice, mas a indenização também não exige a demonstração de sua necessidade, sendo fixada previamente por uma avaliação abstrata. Conclui, assim, o

\footnotetext{
${ }^{74}$ ASCARELLI, Tullio. O conceito unitário do contrato de seguro. In: anônimas e Direito Comparado, p. 241.

${ }^{75}$ MORANDI, Juan Carlos Felix. Estudios de derecho de seguros, p. 96.

${ }^{76}$ ASCARELLI, Tullio, op. cit., p. 221.

${ }^{77}$ Ibidem, p. 215.
} Problemas das sociedades 
doutrinador que na contratação desse tipo de seguro há não somente um ato de previdência e previsão da eventual necessidade futura, mas também o dano consequente do sinistro.

Essa teoria sofreu também sérias objeções no que se refere ao seguro de vida, já que, caso se tratasse de indenização, seria cabível apenas àqueles que dependiam economicamente do de cujus e não a um terceiro livremente nomeado pelo contratante. De fato, não se exige do beneficiário a demonstração de um interesse sobre a vida do segurado e seu direito à indenização não está subordinado à existência de um dano decorrente da morte deste.

Os defensores da Nova Teoria Indenitária, contudo, entendem que o que se pretende indenizar é o dano sofrido pelo próprio segurado e não pelo beneficiário. $\mathrm{O}$ segurado faz justamente uma avaliação preventiva e subjetiva de sua própria vida, atribuindo, porém, essa indenização a um terceiro (beneficiário). $\mathrm{O}$ direito do beneficiário decorre não de seu interesse sobre a vida do segurado, mas, sim, da estipulação que é feita em seu favor. O interesse é do próprio segurado sobre sua vida, interesse esse que se presume juris et de jure, uma vez que não pode ser discutido ${ }^{78}$.

\subsubsection{A Teoria da Transferência do Risco}

A Teoria de Transferência do Risco, mais moderna, tem entre seus expoentes nomes como Besson, Favre, Moitinho de Almeida e, no Brasil, Alvim - este último já salientado no presente estudo. Nessa teoria, o fundamento do contrato de seguro encontrase na transferência do risco do segurado para o segurador, mediante o pagamento de um prêmio.

Renovou-se, aqui, assim como na Teoria da Necessidade, a diferenciação entre o contrato de seguro e a aposta. Na comparação de Alvim, a definição "contrato pelo qual uma pessoa promete a outra uma prestação subordinada à realização de um evento, mediante o pagamento de uma determinada quantia" ${ }^{, 79}$ se aplica tanto ao seguro como ao

\footnotetext{
${ }^{78}$ Nesse sentido, MORANDI, Juan Carlos Felix. Estudios de derecho de seguros, p. 100.

${ }^{79}$ ALVIM, Pedro. O contrato de seguro, p. 114.
} 
jogo. Para o autor, no entanto, o que diferencia os dois contratos são o risco e a transferência de suas consequências econômicas para o segurador. No contrato de seguro, o risco é inerente ao segurado e anterior ao contrato, por isso se exige sua anterioridade, sua existência real e sua função, como causa do contrato ${ }^{80}$. Já na aposta, o risco surge simultaneamente para ambas as partes, de modo que não se pode falar de sua transferência de uma para outra parte ${ }^{81}$.

A teoria foi objeto de várias críticas, tendo em vista a necessária diferença entre o risco que afeta o segurado e o risco assumido pelo segurador. O risco do segurador é estabelecido pelo próprio contrato de seguro, ao passo que o risco do segurado é constituído pelos eventos que podem, das mais diversas formas, afetar o seu patrimônio ou sua integridade física. O risco não pode, portanto, ser transferido ao segurador, mas é pulverizado, diluído por uma massa de segurados, que constituem a mutualidade ${ }^{82}$.

Essa teoria teve o mérito de demonstrar que a prestação da seguradora não se limita ao pagamento da indenização em caso de ocorrência de sinistro, característica comum de todas as demais doutrinas anteriormente formuladas, pois, ao "assumir o risco" que pesa sobre o segurado, a seguradora presta segurança ${ }^{83}$.

\subsection{O modelo adotado pela legislação brasileira: a teoria do interesse legítimo}

As teorias antes mencionadas, apesar de não terem logrado alcançar a unicidade pretendida, tiveram o mérito de destacar os aspectos essenciais do contrato de seguro que permitiram a formulação de uma teoria unitária, adotada pelo Código Civil brasileiro de 2002, consoante art. 757: "Pelo contrato de seguro, o segurador se obriga, mediante o pagamento do prêmio, a garantir interesse legítimo do segurado, relativo a pessoa ou a coisa, contra riscos predeterminados".

\footnotetext{
${ }^{80}$ ALVIM, Pedro. O contrato de seguro, p. 114.

${ }^{81}$ Ibidem, p. 115.

${ }^{82}$ Nesse sentido: FRANCO, Vera Helena de Mello. Contratos no Direito Privado: direito civil e empresarial, p. 282.

${ }^{83}$ Cf. PONTES DE MIRANDA, Francisco Cavalcante. Tratado de Direito Privado, t. XLV, p. 274.
} 
O substitutivo ao capítulo atinente ao contrato de seguro no Código Civil hodierno, elaborado por Comparato, adotou o conceito unitário do contrato de seguro, elegendo o interesse como elemento central tanto do seguro de danos como do seguro de pessoas ${ }^{84}$. De fato, tanto em uma como na outra modalidade, o seguro recai não sobre o bem, mas sobre a relação existente entre uma pessoa e um bem, relação essa denominada interesse. Em ambos os casos, há o interesse na preservação dessa relação e na inocorrência do sinistro.

Comparato invocou, ainda, a noção de garantia, em contraposição ao antigo conceito de indenização, reconhecendo que a prestação do segurador consiste na eliminação de um risco, entendido como "a possibilidade de dano a um interesse" ${ }^{85}$. A indenização, assim, é uma consequência da realização do risco, mas a essência da obrigação do segurador é de prestar segurança. A prestação da garantia representa, pois, o adimplemento da prestação do segurador ${ }^{86}$.

Interesse e garantia são, pois, os elementos inovadores do conceito de contrato de seguro adotado pelo Código Civil de 2002. Ambos os elementos apontados conferem unicidade à definição do tipo contratual, uma vez que, assim como o prêmio e o risco, estão presentes em qualquer contrato de seguro, seja ele de pessoas ou de danos.

Segundo Pedro Alvim, o novo Código Civil adotou a Teoria do Interesse Legítimo de Ehrenberg ${ }^{87}$. Também Pasqualotto faz referência ao que denomina Teoria do Interesse, atribuindo-a, porém, a Buttaro, ao tratar do conceito do contrato de seguro adotado pelo atual Código Civil brasileiro ${ }^{88}$.

${ }^{84}$ Comparato faz referência à doutrina de Ascarelli ao asseverar: "Esta nos parece a mais aceitável 'concepção unitária' do contrato de seguro, aceitando-se a comunhão do gênero econômico do interesse, tanto nos seguros de dano, como nos seguros de pessoas, mas marcando-se a sua diferença específica." (COMPARATO, Fabio Konder. O seguro de crédito, p. 25, nota de rodapé n. 23).

85 "Daí a concepção da obrigação própria do segurador como uma obrigação de garantia, ou dever de prestar segurança (Sicherheitsleistung), e a qualificação do contrato de seguro como um contrato de garantia. Pelo contrato de seguro, o segurado obtém, independentemente do sinistro, e pois da indenização, a transferência à seguradora do risco que afeta o seu interesse". (COMPARATO, Fabio Konder, op. cit., p. 136). E também em CINTRA, Antonio Carlos de Araújo et al. Notas retificadoras sobre seguro de crédito e fiança. In: Direito Empresarial: estudos e pareceres. São Paulo: Saraiva, 1990. p. 444.

${ }^{86}$ Nesse sentido: COMPARATO, Fabio Konder. Obrigações de meio, de resultado e de garantia. In: Ensaios e pareceres do Direito Empresarial. Rio de Janeiro: Forense, 1978. p. 526-527.

87 "Esclarece Vivante que o escritor alemão Ehrenberg defende uma outra teoria: a do interesse legítimo que para ele pouco diverge da teoria da necessidade, tanto que combate ambas com os mesmos argumentos. [...] A teoria do 'direito legítimo' foi acolhida pelo novo código" (ALVIM, Pedro. O seguro e o novo Código Civil. Organização e compilação de Elizabeth Alvim Bonfioli. Rio de Janeiro: Forense, 2007. p. 7).

${ }^{88}$ Pasqualotto, porém, atribui o desenvolvimento da Teoria do Interesse a Buttaro: "A teoria do interesse é uma das explicações conceituais do contrato de seguro. Em verdade, trata-se de indentificar parte do objeto do contrato. A toeria, desenvolvida especialmente por Buttaro, sustenta que o direito não tutela diretamente os bens, mas os interesses" (PASQUALOTTO, Adalberto. Os papéis da álea e da garantia no contrato de seguro: uma visão das leis portuguesa e brasileira. Revista dos Tribunais, São Paulo, n. 885, 2009, p. 20). 
Bechara $^{89}$ e Buranello ${ }^{90}$ referem-se à Teoria do Interesse Legítimo como uma variante da Teoria da Necessidade.

Não há, porém, no substitutivo de Comparato, menção a uma teoria específica, limitando-se o autor a mencionar a insuficiência da Teoria Indenitária adotada no Código Civil antigo e a se referir a Ascarelli, defensor da Nova Teoria Indenitária ${ }^{91}$, mas apenas no que se refere ao interesse segurável.

A concepção de Comparato, de fato, é similar à defendida por Buttaro. O doutrinador italiano ${ }^{92}$ já assinalava que em todos os tipos de seguro há um interesse na inocorrência do sinistro e que o segurado busca justamente uma proteção contra essa possibilidade de dano. A prestação do segurador consiste, assim, na assunção da tutela desse interesse, o que não significa que o segurador deva, ou mesmo possa, impedir a ocorrência do sinistro, mas sim que deve ressarcir o dano, pagando a soma segurada - no caso do seguro de pessoas - ou o prejuízo sofrido - no caso do seguro de dano. Ou seja, o segurado não contrata em razão da ocorrência do dano em concreto, mas sim da possibilidade de sua ocorrência.

O objeto da prestação do segurador não é, portanto, o ressarcimento do dano, mas a segurança que o segurador oferece em troca do pagamento do prêmio pelo segurado. Essa função indenitária do contrato de seguro aparece em todos os ramos. Consiste, porém, não no ressarcimento do dano concretamente verificado, mas na obtenção, pelo segurado, da certeza de que a consequência danosa decorrente de um eventual sinistro ficará a cargo do

\footnotetext{
${ }^{89}$ SANTOS, Ricardo Bechara. Direito do seguro no novo Código Civil e legislação própria. Rio de Janeiro: Forense, 2006. p. 331.

${ }^{90}$ BURANELLO, Renato Macedo. Do contrato de seguro - o seguro garantia de obrigações contratuais. São Paulo: Quartier Latin, 2006. p. 105-106.

91 "Como reconheceu Ascarelli, chefe da fila dos modernos unitaristas (cf. O conceito unitário do contrato de seguro, in: Problemas das sociedades anônimas e Direito Comparado. 2. ed. São Paulo, 1969), há uma diferença de natureza entre a indenização devida nos seguros de dano ou de bens, e aquela estipulada nos seguros de pessoas (seguros de vida e seguro de acidentes pessoais. No primeiro caso, ela é estritamente correspondente ao montante do dano sofrido pelo segurado, enquanto nos seguros de pessoas se relaciona com um prejuízo abstrato, livremente fixado pelo segurado e aceito pelo segurador" (COMPARATO, Fabio Konder. Substitutivo ao capítulo referente ao contrato de seguro no anteprojeto de Código Civil. Revista de Direito Mercantil, n. 5, p. 146).

92 "Infatti se è esatto che anche nell'assicurazione vita, e più in generale nelle assicurazioni di persone, vi è um interesse al non verificarsi del sinistro e, l'assicuratore deve risarcire il danno eventuale, è pure esatto che la prestazione dell'assicuratore non consiste nel risarcimento del danno in concreto verificatosi, ma questa è solo uma consequenza dell'assunzione della cura dell'interesse dell'assicurato [...] Non si vuole così negare la teoria indennitaria, ma solo precisare i limiti in cui la stessa può essere accolta e sopratuttuo constatare che se l'attenzione dello studioso non può fermarsi al momento dell conclusione del contratto più che di risarcimento bisogna parlare di garanzia" (BUTTARO, Luca. L'interesse nell'assicurazione, p. 213-216).
} 
segurador. Essa certeza é representada pela garantia fornecida pelo segurador. Trata-se, pois, de uma adaptação da Teoria Indenitária, em que se substitui a noção de dano pela noção de garantia. 


\section{CAPÍTULO 2}

\section{INTERESSE SEGURÁVEL: CONCEITO E ELEMENTOS}

Apesar da constante referência ao interesse segurável, os textos legislativos são omissos no tocante à sua definição. Encontram-se, no máximo, indícios que servem para clarificar certos aspectos do interesse, que variam conforme a legislação e suas influências teóricas e históricas.

A definição de interesse está intimamente ligada à do próprio contrato de seguro e de sua concepção unitária ou dualista. Uma análise comparativa demonstra que o interesse ora assume uma noção essencial do direito do seguro, ora uma noção acessória, limitada aos seguros de danos ${ }^{93}$.

\subsection{O interesse na legislação brasileira}

No Brasil, conforme ressalta Comparato ${ }^{94}$, o Código Comercial pátrio, que trata exclusivamente do seguro marítimo, seguindo o exemplo do Código francês de $1807^{95}$, acolheu o conceito de interesse, distinguindo-o do bem, objeto da relação, conforme se depreende do art. 677, inciso I, e art. 685, reproduzidos a seguir:

“Art. 677 - O contrato de seguro é nulo:

I - sendo feito por pessoa que não tenha interesse no objeto segurado;

$[\ldots]$

\footnotetext{
93 'Il s'agira de déterminer si l'intérêt d'assurance constitue une notion essentielle du droit des assurances, comme le suggèrent certains droit étrangers, ou bien s'il n'est qu'une notion accessoire, secondaire et d'application limitée, comme l'envisagent le législateur français et la majeure partie de la doctrine française" (PROVOST, Magalie. La notion d'intérêt d'assurance, p. 14).

${ }_{94}^{94}$ COMPARATO, Fabio Konder. O seguro de crédito, p. 24.

${ }^{95}$ Art. 334 : "Toute personne intéressée peut faire assurer le navire et ses accessoires".
} 
Art. 685. Toda e qualquer coisa, todo e qualquer interesse apreciável a dinheiro, que tenha sido posto ou deva pôr-se a risco do mar, pode ser objeto de seguro marítimo, não havendo proibição em contrário".

A distinção entre bem e interesse mostra-se, todavia, dúbia, já que pela redação dos dispositivos supratranscritos, tanto um como outro podem ser "objeto de seguro marítimo". A confusão decorre da origem histórica do seguro, que inicialmente se identificava apenas com o seguro de coisas; assim, objeto do seguro era sempre uma coisa material sujeita a risco $^{96}$, sendo muito posterior a elaboração de uma noção de interesse, conforme salientado no capítulo anterior.

A concepção de interesse trazida pelo Código Comercial é restrita ao seguro marítimo (de dano, portanto) e evidencia o papel do interesse para determinar quem pode contratar o seguro (apenas quem tem interesse no objeto segurado), bem como delimita duas características: deve ser apreciável em dinheiro e lícito.

O Código Civil brasileiro de 1916, por sua vez, apesar de posterior ao Código Comercial, filiou-se à tradicional Teoria da Indenização, sem sequer incluir o interesse na definição do contrato de seguro prevista no art. 1.432: "Considera-se contrato de seguro aquele pelo qual uma das partes se obriga para com a outra, mediante a paga de um prêmio, a indenizá-la do prejuízo resultante de riscos futuros, previstos no contrato”.

Da leitura do capítulo relativo ao contrato de seguro no Código de Clovis Bevilacqua, depreende-se que o objeto do contrato de seguro é o bem, que pode ser tanto uma coisa como a vida e as faculdades humanas (art. 1.440) ${ }^{97}$.

O interesse é mencionado apenas no art. 1.472 do referido diploma legal, que trata do seguro de vida:

“[...] Pode uma pessoa fazer o seguro sobre a própria vida, ou sobre a de outrem, justificando, porém, neste último caso, o seu interesse pela preservação daquela que segura, sob pena de não valer o seguro, em se provando ser falso o motivo alegado.

\footnotetext{
${ }^{96}$ Cf. COMPARATO, Fabio Konder. O seguro de crédito, p. 24.

${ }^{97}$ Art. 1.440: “A vida e as faculdades humanas também se podem estimar como objeto segurável, e segurar, no valor ajustado, contra os riscos possíveis, como o de morte involuntária, inabilitação para trabalhar ou outros semelhantes".
} 
Parágrafo único: Será dispensada a justificação, se o terceiro, cuja vida se quiser segurar, for descendente, ascendente, irmão ou cônjuge do proponente".

No antigo Código Civil, o interesse não é, portanto, elemento contratual e se relaciona apenas com a legitimação para contratar. Sem autorização do segurado, o terceiro não tem legitimidade para contratar em seu nome e necessita demonstrar interesse. Daí por que, alinhado com o posicionamento do antigo Código, ressalta Alvim ${ }^{98}$, que é preciso "justificar as razões de seu interesse pelo seguro de uma coisa cuja perda (o terceiro) procura garantir, embora ela não afete seu patrimônio".

O Decreto-lei n. 73 , de 21 de novembro de $1966^{99}$, voltou a referir-se ao interesse nos $\S \S 2^{\circ}$ e $4^{\circ}$ do art. 11 , que tratam do seguro contratado por simples emissão de bilhete:

\section{“[...]}

$\S 2^{\underline{0}}$ Será lícito à Sociedade Seguradora argüir a existência de circunstância relativa ao objeto ou interesse segurado cujo conhecimento prévio influiria na sua aceitação ou na taxa de seguro, para exonerar-se da responsabilidade assumida, até no caso de sinistro. Nessa hipótese, competirá ao segurado ou beneficiário provar que a Sociedade Seguradora teve ciência prévia da circunstância argüida.

\section{$[\ldots]$}

$\S 4^{0}$ É vedada a realização de mais de um seguro cobrindo o mesmo objeto ou interesse, desde que qualquer deles seja contratado mediante a emissão de simples certificado, salvo nos casos de seguros de pessoas".

O Decreto-lei n. 73/66, a exemplo do Código Comercial, mantém posição dúbia ao estipular que o seguro tanto pode cobrir um objeto como um interesse.

\footnotetext{
98 ALVIM, Pedro. O contrato de seguro, p. 192.

${ }^{99}$ Dispõe sobre o Sistema Nacional de Seguros Privados, regula as operações de seguros e resseguros e dá outras providências.
} 
Conforme observado, o capítulo relativo ao contrato de seguro no Código Civil de 2002, elaborado por Comparato, resgatou o entendimento que já prevalecia na doutrina mais moderna, invocando a noção de garantia e de interesse, em contraposição à antiga noção de indenização e de bem. Adotou, ainda, o conceito unitário do contrato de seguro, elegendo o interesse como elemento central tanto do seguro de danos como do seguro de $\operatorname{pessoas}^{100}$.

O seguro vem conceituado no caput do art. 757: "Pelo contrato de seguro, o segurador se obriga, mediante o pagamento do prêmio, a garantir interesse legítimo do segurado, relativo a pessoa ou a coisa, contra riscos predeterminados”.

Na proposta de Comparato ${ }^{101}$, não constava apenas a expressão "relativo a pessoa ou a coisa" ${ }^{\prime 102}$, acrescida, aparentemente, para explicitar o que já estava implícito: o interesse segurável é exigido tanto no seguro de danos como no seguro de pessoas ${ }^{103}$.

A mudança essencial é que, se no Código Civil de 1916 se segurava uma coisa ou uma pessoa, no Código de 2002 se garante o interesse segurável legítimo do segurado relativo a pessoa ou coisa.

Pontes de Miranda ${ }^{104}$ já antecipava essa noção ao afirmar:

“[...] o que se segura não é propriamente o bem, razão por que nas expressões 'seguro de bens' ou 'seguro de coisas' e 'seguros de responsabilidade', há elipse. O que se segura é o status quo patrimonial ou do ser humano (acidentes, vida). Segura-se o interesse positivo como se segura o interesse negativo".

\footnotetext{
${ }^{100}$ Nesse sentido, destaca Comparato: "Na definição do art. I, estão contidos os quatro elementos essenciais do contrato: o interesse, o risco, a garantia e o prêmio" (COMPARATO, Fabio Konder. Substitutivo ao capítulo referente ao contrato de seguro no Anteprojeto do Código Civil. Revista de Direito Mercantil, n. 5, p. 143-152).

101 "Art. I. Pelo contrato de seguro, o segurador se obriga, mediante o pagamento do prêmio, a garantir interesse legítimo do segurado, contra riscos predeterminados" (ibidem, p. 147).

${ }^{102}$ No Projeto de Lei n. 3.555/2004, o contrato de seguro é difinido no art. 1" :Pelo contrato de seguro, a seguradora se obriga, mediante um prêmio equivalente, a garantir interesse legítimo do segurado ou do beneficiário, contra riscos predeterminados".

${ }^{103} \mathrm{O}$ acréscimo da expressão "relativo à pessoa ou coisa" é inadequado, tendo em vista que o interesse também pode referir-se a patrimônio, que não se caracteriza como "coisa", pertencendo à categoria de seguro de dano. A esse propósito, comenta Alvim: "A expressão 'interesse legítimo' tem um sentido amplo. Abrange tanto o seguro de pessoa como o de dano, aí denominado impropriamente de seguro de coisa" (ALVIM, Pedro. O seguro e o novo Código Civil, p. 7).

${ }^{104}$ PONTES DE MIRANDA, Francisco Cavalcante. Tratado de Direito Privado, t. XLV, p. 275.
} 
Em razão de, conforme salientado, a legislação ser omissa no que alude à definição de interesse, coube à doutrina desempenhar esse papel.

\subsection{As correntes doutrinárias sobre a definição de interesse segurável}

\subsubsection{Interesse como relação ${ }^{105}$ - corrente majoritária}

O alemão Victor Ehrenberg (1851-1929) foi o primeiro a definir o interesse como uma relação entre uma pessoa e uma coisa, quando publicou em 1893 diversos estudos sobre a matéria. Para ele, o interesse tem uma dupla função no contrato de seguro: diferenciar o seguro da aposta e permitir a realização de um seguro sobre o mesmo bem por mais de uma pessoa. $\mathrm{O}$ doutrinador em comento assevera que nenhum seguro de dano pode ser concluído sem a demonstração do interesse segurável ${ }^{106}$. Segundo Ehrenberg, o interesse é "a relação em razão da qual uma pessoa é submetida, por causa de um evento determinado, a um dano patrimonial ${ }^{107}$.

Ehrenberg exerceu forte influência sobre o Direito inglês, conforme se verifica do Marine Insurance Act $1906^{108}$, ao definir que há interesse no seguro marítimo quando uma pessoa possui uma relação, jurídica ou equiparável, com a propriedade segurável sob risco, em consequência da qual obtém um benefício por sua chegada em segurança ou sofre um prejuízo por sua perda ou dano, ou que ainda possa incorrer em responsabilidade em relação a ela.

\footnotetext{
${ }^{105}$ É cediço que a teoria sobre a relação jurídica, bastante consagrada - se não a predominante -, apregoa que a relação somente se estabelece entre dois sujeitos, e nunca entre um sujeito e um objeto. Essa caracterização põe em relevo o caráter intersubjetivo do fenômeno jurídico e a função do direito como mecanismo de organização e pacificação social. Importa destacar, todavia, que aqui não se está utilizando o vocábulo relação (rapporto) na exata acepção que é empregada no âmbito da Teoria Geral da Relação Jurídica, mas sim para expressar a ideia de ligação de um bem a uma pessoa, intermediada pela noção de interesse. (Acerca da Teoria Geral da Relação Jurídica e de seus elementos, cf. DOMINGUES DE ANDRADE, Manuel A. Teoria geral da relação jurídica. Coimbra: Almedina, 1998. v. 1/2.)

${ }^{106}$ PROVOST, Magalie. La notion d'intérêt d'assurance, p. 250.

${ }^{107}$ FERRARINI, Sergio. L'interesse nell'assicurazione, p. 8.

108 "[...] 5 0.- (1) Subject to the provisions of this Act, every person has an insurable interest who is interested in a marine adventure. (2) In particular, a person is interested in a marine adventure where he stand in any legal or equitable relation to the adventure or to any insurable property at risk therein, inconsequence of which he may benefit by the safety or due arrival of insurable property, or may be prejudiced by its loss, or damage hereto, or by the detention thereof, or may incur liability in respect thereof."
} 
Como se verifica, os pontos centrais do conceito - relação entre pessoa e coisa e dano patrimonial - restringiam o interesse ao seguro de danos, já que essa formulação não se aplicava ao seguro de pessoas ${ }^{109}$. O entendimento esposado prevalece até os dias de hoje em muitas legislações, influenciando, assim, o conceito de interesse. É o caso da França, cujo atual Código de Seguros manteve no art. L. 121-6 a mesma redação do art. 32 da Lei do Contrato de Seguro, de 13 de julho de 1930. O referido dispositivo está incluído no capítulo pertinente aos seguros de danos não marítimos e se refere exclusivamente ao interesse de conservação de uma coisa: “Art. L. 121-6: Toute personne ayant intérêt à la conservation d'une chose peut la faire assurer. Tout intérêt direct ou indirect à la nonréalisation d'un risque peut faire l'objet d'une assurance".

A posição de Ehrenberg também influenciou o Direito italiano, conforme se infere das obras de Ferrarini, Buttaro e Donati; todavia, a doutrina italiana foi igualmente influenciada pela obra de Bruck $^{110}$ e substitui a referência de Ehrenberg ao dano patrimonial pela noção de risco, definindo o interesse segurável como "a relação de uma pessoa com uma coisa, ameaçado por um risco determinado"111.

Consoante explica Ferrarini, o interesse, entendido como uma relação de uma pessoa com uma coisa, existe independentemente de um risco o ameace. O risco, assim, não constitui a premissa do interesse pois a relação e a sorte da relação são independentes. Do ponto de vista securitário, no entanto, o interesse somente é considerado ao ser ameaçado por um risco que, no seu entender, inclui a noção de dano patrimonial ou econômico, de maneira que a definição de interesse não necessita da especificação da natureza econômica da relação, conforme coloca Ehrenberg ${ }^{112}$. Para Medina, no entanto, não se deve incluir na definição de interesse segurável elementos que são próprios do risco,

\footnotetext{
109 Diz Ferrarini: "Appare ora chiaramente come il concetto di interesse sia proprio ed exclusivo dell assicarazioni contro i danni. La definizione stessa di interesse, quale rapporto di persona e cosa, esclude la possibilità di applicare il concetto nell'assicurazione vita." (FERRARINI, Sergio. L'interesse nell'assicurazione, p. 11). (Tradução livre: "Aparece agora claramente como o conceito de interesse é próprio e exclusivo das seguros de danos. A própria definição de interesse, da relação de pessoa e coisa, exclui a possibilidade de aplicar o conceito no seguro de vida".)

${ }^{110}$ BRUCK, Zum Begriff, p. 123; WINKLER, Die Gevinnversicherung, Hamburgo, 1930, p. 8, os quais falam de relação assegurado contra um risco determinado. Análoga a definição de VANARD (La théorie de l'intérét, cit., in Ver. gén. des assur. Terr., 1932, p. 699), segundo o qual é interesse "a relação entre uma pessoa e um bem ou um conjunto de bens, havendo um valor econômico, mas exposto a perigos, a realização dos quais faz surgir a necessidade de um valor de substituição ou de uma indenização".

111 Diz Ferrarini: "Così non differisce sostanzialmente dalla nostra la definizione dell'Ehrenberg" (FERRARINI, Sergio, op. cit., p. 8).

${ }^{112}$ Ibidem.
} 
como a noção de dano ou de necessidade econômica. Segundo o autor mexicano, "sempre que exista uma relação lícita de caráter econômico entre objeto e sujeito haverá interesse segurável, mas nem sempre haverá uma necessidade econômica (risco e, se for o caso, sinistro)" "113. Conclui, assim, que "interesse segurável é simplesmente a relação lícita de caráter econômico que existe entre a pessoa que segura o objeto que é segurado"114.

Há que registrar-se, porém, a diferença entre inserir na definição do interesse segurável o risco, como sustenta Ferrarini, e o dano, criticado por Medina. Conforme assinala Buttaro $^{115}$, a existência do risco não integra o conceito de interesse, mas constitui um requisito para que o interesse seja segurável. Da mesma forma, o dano também não constitui um elemento do interesse, na medida em que o interesse segurável existe independentemente da ocorrência do sinistro.

A doutrina brasileira teve, também, clara inspiração em Ehrenberg ao definir o interesse como relação, aplicável tanto ao seguro de dano como ao de pessoa ${ }^{116}$. Comparato, invocando Donati, define o interesse segurável como "a relação existente entre o segurado e a coisa ou a pessoa sujeita ao risco"117.

Na mesma trilha, Mello Franco assinala que "o interesse é uma relação de valor em sentido amplo e, perante o direito securitário, apresenta-se como uma situação de vantagem ou desvantagem para o segurado, quer com relação a uma pessoa, quer com relação a uma coisa" ${ }^{118}$. Toledo Piza ${ }^{119}$, em sua tese de doutorado sobre o contrato de resseguro, também salienta que o interesse "se reporta a um bem sujeito a risco, que é a possibilidade de um evento desvantajoso".

Na doutrina brasileira, destaca-se a posição de Tzirulnik, Cavalcanti e Pimentel, que definem o interesse como uma relação juridicamente relevante, ou seja, protegida pela

\footnotetext{
113 MAGALLANES, Pablo Medina. O interesse segurável. In: III FÓRUM DE DIREITO DO SEGURO “JOSÉ SOLLERO FILHO”. São Paulo: Manuais Técnicos de Seguros: IBDS, 2003. p. 387.

${ }^{114}$ Ibidem, p. 394

${ }^{115}$ BUTTARO, Luca. L'interesse nell'assicurazione, p. 14.

${ }^{116}$ Buttaro, em que pese a posição do Direito italiano, defende que essa definição do interesse se aplica a ambos os ramos securitários: "L'interesse, così determinato, no constituisce un requisito esssenziale esclusivamente dell'assicurazione contro i danni, como protrebbe sembrare a chi osserva l'art, 1904c.c., ma è comune a tutti i tipi di assicurazione, giacchè in ogni caso vi è un rapporto procedente che l'assicurato intente tutelare contro i pericoli che lo minacciano, sia che si tratti di un interesse a un bene sia che si tratti dell'interesse alla propria vita o all'integrità della propria persona" (ibidem, loc. cit.).

${ }^{117}$ COMPARATO, Fabio Konder. O seguro de crédito, p. 26.

118 FRANCO, Vera Helena de Mello. Lições de direito securitário: seguros terrestres privados. São Paulo: Maltese, 1993. p. 39.

119 PIZA, Paulo Luiz de Toledo. Contrato de resseguro: tipologia, formação e direito internacional. São Paulo: Manuais Técnicos de Seguros: IBDS, 2002. p. 203.
} 
ordem jurídica e, por isso, merecedora da proteção securitária. Nas palavras desses doutrinadores, interesse "consiste na posição juridicamente relevante de um sujeito de direito para com um bem da vida" ${ }^{20}$. Não incluem, portanto, a sujeição do interesse a risco, entendido como um evento desvantajoso para o segurado ou interesse na conservação do bem. Os autores sustentam que é a qualidade de legítimo, exigida pelo legislador para qualificar o interesse, que visa "relevar a importância de que a pertinência entre o sujeito e o bem da vida seja de ordem a fazer com que aquele queira sua preservação, não desdenhe o status quo e não queira, nem lhe seja vantajosa, a realização do risco garantido" ${ }^{, 121}$.

A posição defendida pelos doutrinadores apontados assemelha-se à definição de interesse que consta da hodierna legislação securitária portuguesa (Decreto-lei português n. 72/2008), cujo inciso 1 do art. $43^{122}$ exige que o segurado tenha um interesse digno de proteção legal, fazendo menção específica, porém, que esse interesse seja relativo ao risco coberto.

\subsubsection{Interesse como valor}

Kisch, também alemão, criticou a doutrina de Ehrenberg defendendo que o conceito de relação ou de situação econômica é puramente formal, incolor, e não coloca em relevo o caráter essencial do interesse, de estabelecer um valor patrimonial positivo ${ }^{123}$. Para Kisch, portanto, o interesse se identifica com o próprio bem que, por causa do sinistro, é subtraído

\footnotetext{
${ }^{120}$ TZIRULNIK, Ernesto; CAVALCANTI, Flávio de Queiroz B.; PIMENTEL, Ayrton. O contrato de seguro de acordo com o novo Código Civil brasileiro. São Paulo: Revista dos Tribunais, 2003. p. 32.

${ }^{121}$ Ibidem.

122 “Artigo 43ํ- Interesse

1 - O segurado deve ter um interesse digno de protecção legal relativamente ao risco coberto, sob pena de nulidade do contrato.

2 - No seguro de danos, o interesse respeita à conservação ou à integridade de coisa, direito ou património seguros.

3 - No seguro de vida, a pessoa segura que não seja beneficiária tem ainda de dar o seu consentimento para a cobertura do risco, salvo quando o contrato resulta do cumprimento de disposição legal ou de instrumento de regulamentação colectiva de trabalho."

${ }^{123}$ KISCH, W. Handbuch dês Privatversicherungsrechtes. München-Berlin-Leipzig: Die Lehre Von dem Versicherungsinteresse, 1922. t. III, p. 16. In: FERRARINI, Sergio. L'interesse nell'assicurazione, p. 6; e PROVOST, Magalie. La notion d'intérêt d'assurance, p. 254.
} 
do segurado. Nesse sentido, interesse é definido como o valor em dinheiro do bem patrimonial concreto, exposto ao risco de perda ${ }^{124}$.

O pensamento de Kisch é ilustrado com propriedade no seguinte trecho:

“[...] se eu seguro como proprietário a minha casa contra incêndio, não seguro a relação na qual me encontro com essa, mas o valor patrimonial da casa, com o qual eu tenho uma relação. Se depois a casa é inteiramente destruída pelo fogo, do ponto de vista securitário interessa não o fato de que, por causa disso, vem a cessar a minha relação (como tal, então em senso puramente formal) com essa, mas o fato, ao invés, de que a mim foi subtraído um valor material. E ainda, na hipótese de que a minha casa somente sofra um dano, a minha relação com essa (a minha propriedade) permanece a mesma que no início, porque isso, a causa do sinistro não é nem anulada nem modificada, assim como não vem, nem pode vir, a ser restaurada pela indenização securitária. Em conclusão: quando seguro a minha casa contra o incêndio, eu quero segurar, ou seja, proteger, não a relação que me liga a essa, mas aquilo que essa significa para mim: eu faço o seguro por causa da relação, não pela relação, não pela sua proteção" ${ }^{\prime 25}$.

A doutrina de Kisch foi encampada por parte da doutirna francesa, destacando-se Picard e Besson que definem o interesse como "o valor monetário do bem exposto à perda ou o valor patrimonial que pode ser perdido pelo segurado ou pelo beneficário em razão do sinistro. Para ser segurável, o interesse deve ser econômico e apreciável em dinheiro" ${ }^{\text {"26 }}$. Ferrarini critica o pensamento doutrinário de Kisch por identificar o interesse com o

\footnotetext{
${ }^{124} \mathrm{KISCH}, \mathrm{W}$. Handbuch dês Privatversicherungsrechtes, p. 25. In: FERRARINI, Sergio. L'interesse nell'assicurazione, p. 9; e PROVOST, Magalie. La notion d'intérêt d'assurance, p. 254-255.

${ }^{125}$ Tradução livre do trecho de KISCH, W. Handbuch dês Privatversicherungsrechtes, p. 15-16, citado em FERRARINI, Sergio. L'interesse nell'assicurazione, p. 16, também referido por PROVOST, Magalie. La notion d'intérêt d'assurance, p. 254.

${ }^{126}$ Tradução livre do original: "La valeur pécuniaire exposée à la perte du bien patrimonial envisagé ou la valeur patrimonial pouvant être perdue pour l'assuré ou le bénéficiarie à la suite du sinistre. Pour être assurable, un intérêt doit donc être économique et appréciable en argent" (PICARD, M.; BESSON, A. Les assurances terrestres. Paris: LGDJ, 1982. t. 1: Le contrat d'assurance, p. 296. In: PROVOST, Magalie, op. cit., p. 255).
} 
próprio bem, afastando a ideia de relação. Para o autor italiano, o bem não tem um valor em si mesmo, objetivo, mas sim por causa de determinada relação que liga o bem à pessoa. Ou seja, o valor patrimonial não é dado pelo bem, mas sim pela relação ${ }^{127}$.

\subsubsection{Interesse como expectativa de perda patrimonial}

A terceira teoria define o interesse como uma expectativa de perda patrimonial. Essa definição foi destacada no célebre julgamento do caso Lucena versus Craufurd ocorrido em 1806, em que se considerou que tem interesse na preservação de um bem aquele que se beneficia de sua existência ou de sua perda ${ }^{128}$.

No julgamento apontado, considerou-se que mesmo aquele que não tiver um direito de propriedade sobre o bem pode ter um interesse segurável, desde que demonstre a suscetibilidade de sofrer um dano, ou um prejuízo, ou ainda de ser responsabilizado em razão de sua destruição ${ }^{129}$. Isso explica a denominação dessa teoria como Factual Expectancy (expectativa de fato) em oposição à Legal Right Theory (teoria do direito), ainda hoje as duas principais teorias vigentes no direito americano ${ }^{130}$.

A teoria em comento teve o mérito de considerar como titulares de um interesse segurável qualquer pessoa passível de sofrer um dano, ainda que não detentora de um direito real sobre o bem.

\footnotetext{
${ }^{127}$ FERRARINI, Sergio. L'interesse nell'assicurazione, p. 17.

128 Lucena -v- Craufurd (1802) 3 Bos \& P 75; (1802) 127 ER 42 Ex Ch. Disponível em: 〈http://www.swarb.co.uk/lisc/Insur18001849.php>. Acesso em: 10 nov. 2010. (Versão original: "A man is interested in a thing to whom advantage may arise or prejudice happen from the circumstances which may attend it; and whom it imports, that its condition as to safety or other quality should continue; interest does not necessarily imply a right to the whole or part of the thing, nor necessarily and exclusively that which may be the subject of privation, but the having some relation to, or concerning the subject of the insurance; which relation or concern, by the happening of the perils insured against, may be so affected as to produce a damage, detriment or prejudice to the person insuring. And where a man is so circumstanced with respect to matters exposed to certain risks or dangers, as to have a moral certainty of advantage or benefit, but for those risks or dangers he may be said to be interested in the safety of the thing. To be interested in the preservation of a thing, is to be so circumstanced with respect to it as to have benefit from its existence, prejudice from its destruction. The property of a thing and the interest devisable from it may be very different; of the first the price is generally the measure, but by interest in a thing every benefit and advantage arising out of or depending on such thing may be considered as being comprehended.")

${ }^{129}$ PROVOST, Magalie. La notion d'intérêt d'assurance, p. 257.

${ }^{130}$ STEMPEL, Jeffrey W. Stempel on insurance contracts. $3^{\text {rd }}$ ed. New York: Aspen Publishers, 2007, v. I, p. 23.
} 
A teoria do Factual Expectancy foi muita bem recebida, em especial pelos doutrinadores alemães, em meados do século $\mathrm{XIX}^{131}$, que verificaram que o interesse segurável, no seguro de dano, era a outra face do princípio indenitário, ou seja, se o seguro não deve indenizar além do prejuízo efetivamente sofrido (princípio indenitário), apenas aqueles que sofrem um prejuízo é que podem ter um interesse segurável ${ }^{132}$.

É com fundamento nessa compreensão que o interessse segurável é definido em muitos países, em especial naqueles de commom law, destacando-se a Inglaterra ${ }^{133}$, o Canadá $^{134}$ e a Austrália ${ }^{135}$, no que se refere aos seguros de dano.

Na França, esse conceito é adotado por Beudant: "O segurado tem um interesse na medida em que ele sofre, em caso de ocorrência do risco, um prejuízo pecuniário ou, ao

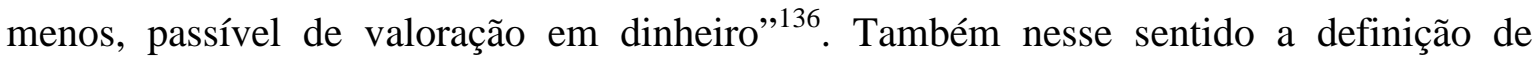
Charré-Servau, segundo a qual a noção de interesse especificamente no seguro é uma condição de validade do contrato. Na verdade, uma pessoa só pode comprar um seguro se tiver interesse na conservação do bem (art. L 121-6 do Código de Seguros), por ser suscetível de sofrer um prejuízo econômico em decorrência de uma perda patrimonial tanto direta (como proprietário ou usuário) como indireta (como credor do proprietário do bem, por exemplo). Além disso, qualquer pessoa cuja atividade possa causar danos e afetar seus

\footnotetext{
${ }^{131}$ PROVOST, Magalie. La notion d'intérêt d'assurance, p. 258.

${ }^{132}$ STEMPEL, Jeffrey W. Stempel on insurance contracts, v. I, p. 22.

${ }^{133}$ Nesse sentido: "Insurable interest itself was not defined by the Acts. Instead the classic definition comes from the 1806 case of Lucena v Craufurd. It states, at least, in the context of indemnity insurance, that insurable interest is: "A right in property, or a right derivable out of some contract about the property, which in either case may be lost upon some contingency affecting the possession or enjoyment of the party".(THE LAW COMISSION AND THE SCOTTISH LAW COMISSION. Insurance contract law. Issues Paper 4. Insurable Interest, 14.01.2008. p. 7. Disponível em: www.lawcom.gov.uk/.../Insurance_Contract_Law_ Issues_Paper_4.pdf. Acesso em: 10 set. 2010).

${ }^{134}$ Nessa trilha, o autor canadense Laverty: "If you are liable to suffer a direct and immediate loss or liability, appreciable in money from the happening of a certain event, then that event in one upon which you can obtain insurance, provided that there is nothing contra bonos more or public policy". (LAVERTY, F. J. The insurance Law of Canadá. $2^{\text {nd }}$ ed. Toronto: Carswell, 1936, p. 77. In: PROVOST, Magalie, op. cit., p. 259).

135 O relatório da Comissão de Reforma da Lei australiana n. 20 (Camberra, 1982) diz o seguinte: "Abandonment of the strict proprietary interest test in favour of one based on economic loss would allow more flexibility to insurer and to the insuring public, without in any way promoting gaming and wagering in the form of insurance or adding to the risk of destruction of the property insured [...] Legislation should provide that, where an insured is economically disadvantage by damage to or destruction of the insured property, the insured should not be relieved of liability by reason only that the insured did not have a legal or equitable interest in the property" (PROVOST, Magalie, op. cit., p. 260).

${ }^{136}$ Cn. Beudant, n. 684, p. 253. In: PROVOST, Magalie, op. cit., p. 260. Versão original: "L'assuré a un intérêt dans la mesure où il subit, au cas de réalisation du risque, un préjudice pécuniaire ou au moins susceptible d'etre évalué en argent".
} 
ativos com uma dívida de responsabilidade, tem interesse numa apólice de seguros que cubra essa responsabilidade ${ }^{137}$.

\subsubsection{Interesse de natureza moral}

As correntes doutrinárias até aqui analisadas consideram o interesse apenas como uma relação de natureza econômica, ainda que aplicável tanto ao seguro de dano como ao seguro de pessoas ${ }^{138}$. A diferença, segundo lição ministrada por Comparato, é que o interesse "pode apresentar um conteúdo econômico objetivamente determinado, como nos seguros de dano, ou livremente estimável pelo segurado, como no seguro de pessoas"139; mas, num e noutro caso, a relação entre o segurado e o bem há de ter conteúdo econômico $^{140}$.

Uma das primeiras definições de que se tem registro do interesse segurável, admitindo-se, também, sua natureza moral data de 1886 e se deu num julgamento da Corte da Pensilvânia, nos Estados Unidos, no processo Corson's App ${ }^{141}$. O caso discutia um

${ }^{137}$ LANDEL, J.; CHARRE-SERVEAU, M. Lexique des terms assurances. $5^{\mathrm{e}}$ éd. L'Argus de l'Assurance, 2007. p. 286. In: PROVOST, Magalie. La notion d'intérêt d'assurance, p. 260. (Versão original: "La notion d'intérêt, spécifique aux assurance de dommages, est une condition de la validité du contrat. En effet, la souscription d'une assurance n'est possible que par une personne qui a 'intérêt a la conservation de la chose' (L-121-6 C. assur.), parce qu'elle est suscepbible de subir un préjudice économique du fait de la perte du bien, directment (en tant que propriétaire ou utilisateur) ou indirectment (en tant que créancier du propriétaire de la chose, par example). De même, toute personne dont l'activité peut être source de dommages susceptibles d'affecter son patrimoine d'une dette de responsabilité a intérêt à souscrire une assurance couvrant sa responsabilité".)

${ }^{138}$ Provost entende que o interesse de natureza econômica é de difícil adaptação ao seguro de pessoas: "Le pays qui exigent um intérêt de nature économique pour qualifier le contrat d'assurance ont elaboré ce principe à partir de l'assurance de choses. Pourtant, cette analyse s'adapte difficilement à d'autres types de contrats d'assurance" (PROVOST, Magalie, op. cit., p. 265).

${ }^{139}$ COMPARATO, Fabio Konder. O seguro de crédito, p. 25.

140 Nesse sentido: FRANCO, Vera Helena de Mello. Lições de direito securitário: seguros terrestres privados, p. 291; e TZIRULNIK, Ernesto; CAVALCANTI, Flávio de Queiroz B.; PIMENTEL, Ayrton. $O$ contrato de seguro de acordo com o novo Código Civil, p. 34-35.

141 "An insurable interest [...] is not necessarily a definite pecuniary interest, such as recognized and protected at law; it may be contingent, restricted to a time, or indeterminate in amount, but it must be actual, such as will reasonably justify a well grounded expectation of advantage depended upon the life insured, so that the purpose of the party effecting the insurance may be to secure that advantage, and not merely to put a wager upon human life [...]. It is not necessary that the expectation of advantage or benefit should be always capable of pecuniary estimation; for a parent has an insurable interest in the life of his child, and a child in the life of his parent; a husband in the life of his wife, and a wife in the life of her husband. The natural affection in cases of this kind is considered as more powerful - as operating more efficaciously - to protect the life of the insured than any other consideration. But in all cases there must be a reasonable ground, founded upon the relations of the parties to each other, either pecuniary or of blood or affinity, to expect some benefit or 
seguro de vida feito por um pai. A decisão enfatiza não somente que o interesse segurável não precisa ser necessariamente pecuniário ou passível de uma estimativa em dinheiro, como também que a afeição decorrente das relações de parentesco tem um poder ainda maior do que qualquer outro de proteger a vida segurada. Ressalta, ainda, que em todos os casos deve haver um motivo razoável, fundado sobre as relações das partes entre si, quer pecuniários, quer de parentesco sanguíneo ou não, de que algum benefício ou vantagem decorra da continuidade da vida do segurado.

Esse entendimento foi adotado por algumas legislações estatais dos Estados Unidos, incluindo a de Nova Iorque, cujo Código de Seguros de 2006 prevê, no § 3.205, que a expressão interesse segurável, nos seguros de pessoas, significa: (a) no caso de pessoas intimamente relacionadas por laços de sangue ou por lei, um interesse substancial decorrente do amor e da afeição; (b) no caso de outras pessoas, um interesse legal e econômico de continuidade da vida, da saúde e da integridade corporal da pessoa segurada, que se distingue do interesse resultante ou unicamente motivado pelo valor da morte, da invalidez, ou dano corporal ${ }^{142}$.

Defensora de que o interesse pode ser de natureza tanto econômica como moral, Provost define o interesse como a antecipação de um possível dano temido pelo subscritor da apólice, ou seja, o interesse redunda no próprio interesse pela não realização de um risco, que pode acarretar um prejuízo tanto patrimonial como extrapatrimonial ${ }^{143}$. Essa compreensão do interesse decorre do fato da autora caracterizá-lo como um componente do risco. A natureza do interesse segurável depende, assim, da natureza do dano causado pela realização do risco: será patrimonial, se o sinistro acarretar uma perda patrimonial; será moral ou extrapatrimonial, quando houver um sofrimento moral ou psíquico em decorrência do sinistro ${ }^{144}$.

advantage from the continuance of the life of the assured. Otherwise the contract is a mere wager, by which the party taking the policy is directly interested in the early death of the assured." (In: PROVOST, Magalie. La notion d'intérêt d'assurance, p. 262-263).

142 “ $[\ldots] \S 3.205$. Insurable interest in the person; consent required; exceptions.

(a) In this section: (1) The term, 'insurable interest' means:

(A) in the case of persons closely related by blood or by law, a substantial interest engendered by love and affection; (B) in the case of other persons, a lawful and substantial economic interest in the continued life, health or bodily safety of the person insured, as distinguished from an interest which would arise only by, or would be enhanced in value by, the death, disablement or injury of the insured."

143 “[...] l'intérêt d'assurance est l'antecipation d'un dommage éventuel redouté par le souscripeteur" (PROVOST, Magalie, op. cit., p. 265).

144 "Par ailleurs, la nature de l'intérêt d'assurance est celle des conséquences de la réalisation du risque. Soit le sinistre cause un dommage patrimonial ou provoque un besoin et l'intérêt d'assurance du souscripteur est 


\subsection{Elementos do interesse segurável}

Da definição majoritária de interesse, qual seja, de uma relação entre uma pessoa e uma coisa, exposta a um risco determinado, emergem os seguintes elementos: o bem, a relação e a sua exposição a um risco determinado.

\subsubsection{O bem}

O bem é o objeto da relação ao qual o interesse se reporta. Bem pode ser tanto uma pessoa como qualquer coisa material ou mesmo imaterial, com a qual o sujeito tenha uma relação.

No seguro de danos, o bem pode ser tanto um objeto singular (um livro, uma casa, um barco) como um conjunto de bens da mesma espécie (uma coleção de quadros, uma biblioteca, um rebanho), ou, ainda, um conjunto de bens de espécies diferentes (um edifício e seu conteúdo, as mercadorias guardadas em um depósito, uma indústria, incluindo prédio, equipamentos e matéria-prima) ${ }^{145}$.

Se envolver um conjunto de bens, é necessário verificar a possibilidade de se tratar de um conjunto de bens singulares ou de um todo único e orgânico distinto dos bens que o compõem. No primeiro caso, cada bem conserva sua individualidade e o interesse diz respeito a cada um deles, ou seja, ele se refere à soma dos interesses singulares que ligam a pessoa a cada um dos bens que formam um conjunto. Já no segundo, o conjunto de bens compõe uma unidade autônoma e o interesse sobre esse todo pode não corresponder ao interesse sobre cada bem individualmente considerado. Ferrarini ${ }^{146}$ exemplifica com uma coleção completa de livros, mas pode ser também um conjunto de máquinas que compõe a

\footnotetext{
de nature économique; soit le sinistre cause un dommage extra-patrimonial et le intérêt de assurance du souscripteur est de nature morale. Dans tout le cas, il suffit uqe le souscripteur ou le bénéficiaire ait un intérêt à la nor-réalisation du risque pour que le contrat soit qualifié d'assurance" (PROVOST, Magalie. La notion d'intérêt d'assurance, p. 267).

${ }^{145}$ Nesse sentido: FERRARINI, Sergio. L'interesse nell'assicurazione, p. 22.

146 Ibidem, p. 23.
} 
linha de produção de uma indústria, hipóteses em que o interesse sobre o todo pode ser maior do que a soma dos interesses sobre os bens singulares.

Ainda, conforme observado, o bem, objeto da relação, pode ser imaterial. O exemplo clássico é o seguro de crédito que se reporta à obrigação de um terceiro, no qual o objeto do interesse é o direito de fruição do credor (segurado) à prestação de devedor. ${ }^{147}$ Comparato explica que "o interesse segurável no seguro de crédito não é propriamente o crédito, e sim o valor econômico que este crédito representa no patrimônio do segurado" ${ }^{148}$. Ou seja, aqui, o objeto do interesse, o bem, é o direito do credor, ao passo que a relação existente entre o sujeito e o bem é a operação de crédito.

É preciso não confundir o seguro de crédito com o seguro de coisa ou de pessoas que visa proteger o bem dado em garantia e, subsidiariamente, o crédito. Ferrarini ${ }^{149}$ e Comparato $^{150}$ invocam o mesmo exemplo: o seguro contratado em favor do credor hipotecário sobre uma casa dada em garantia. Pode ser um seguro de incêndio e, nesse caso, objeto do interesse é o próprio bem e a relação existe em razão do direito real (hipoteca) existente entre o credor e o bem. Mas, se o seguro for de insolvência, o objeto do interesse já não será a casa e, sim, o direito do credor de receber o pagamento pelo crédito concedido. Aqui, o objeto do interesse é o próprio direito obrigacional. Por isso, em geral, o direito pode constituir a relação ou o objeto do interesse. Será a própria relação quando se trata de um direito real sobre uma coisa e será o objeto na hipótese de se tratar de um direito obrigacional, ou seja, do direito à prestação do devedor.

Ainda, o bem, objeto da relação, pode ser o patrimônio do segurado. Mas, o patrimônio, aqui, não deve ser compreendido em seu sentido econômico, ou seja, como o conjunto de bens, direitos e obrigações de uma pessoa, apreciáveis em dinheiro. Patrimônio, como objeto do interesse, é a situação econômica criada pelas necessidades de uma pessoa e os meios disponíveis para sua satisfação. É irrelevante a efetiva consistência patrimonial de uma pessoa, não interessando se existe um patrimônio postivo ou negativo, bastando verificar que a ocorrência de um evento impactará negativamente na situação econômica de algúem, dando origem a um novo débito, ou a uma nova necessidade.

Exemplo típico de seguro de patrimônio é o seguro de responsabilidade civil. Essa modalidade securitária tem por objetivo proteger o patrimônio do segurado do débito

\footnotetext{
${ }^{147}$ Outro exemplo possível é o seguro garantia de obrigações contratuais.

${ }^{148}$ COMPARATO, Fabio Konder. O seguro de crédito, p. 33.

${ }^{149}$ FERRARINI, Sergio. L'interesse nell'assicurazione, p. 23.

${ }^{150}$ COMPARATO, Fabio Konder, op. cit., p. 14.
} 
oriundo de ato ilícito culposo. O patrimônio, como objeto do interesse, constitui uma universalidade, única e indivisível. Diverso do bem singularmente considerado, não é possível estabelecer o dano máximo que pode sofrer um patrimônio. Daí por que no seguro de responsabilidade civil, não há limite para a fixação da importância segurada.

Há quem defenda que o objeto do interesse, nesse caso, é um não bem. Nessa concepção, bem são as coisas, o patrimônio ativo e a expectativas de patrimônio futuro e não bem são justamente as dívidas presentes (patrimônio passivo) e futuras (expectativas negativas). Assim, o dano que pode atingir a relação com um bem resulta na diminuição do patrimônio ativo, ao passo que na relação com um não bem há um aumento do patrimônio $\operatorname{passivo~}^{151}$.

Em verdade, o objetivo comum de qualquer seguro de dano é a manutenção da integridade, do status quo patrimonial do segurado. A diferença reside em se essa manutenção se refere a um bem concretamente determinado, que integra o patrimônio, ou se ao patrimônio como um todo.

Note-se, ainda, que o bem concreto, ou mesmo o direito, é passível de ser individualizado com exatidão; por exemplo, o endereço e as dimensões de uma casa, o contrato que origina um direito de crédito e seu respectivo valor. E mesmo uma coletividade de bens pode ser descrita como os bens que guarnecem uma casa, os livros de uma biblioteca, as mercadorias guardadas em depósito. No seguro de coisa, a determinação do bem é um requisito necessário, enquanto no seguro de patrimônio, isso não é possível e, portanto, não se pode exigir a sua descrição. Basta, como assinalado, a indicação da causa que pode resultar em uma diminuição patrimonial do segurado e a fixação do limite até onde responde o segurador. O dano se verifica pelo simples surgimento de uma dívida a cargo do segurado decorrente da causa apontada.

No seguro de pessoas, o bem objeto do interesse é a própria pessoa humana. $\mathrm{O}$ art. 757 do Código Civil brasileiro é claro ao prever o interesse "relativo à pessoa ou à coisa". Conforme salientado, o mesmo não ocorre em algumas legislações estrangeiras, a exemplo

${ }^{151}$ Cf. FERRARINI, Sergio. L'interesse nell'assicurazione, p. 25. 
da francesa ${ }^{152}$, italiana ${ }^{153}$ e alemã ${ }^{154}$, que não incluem o interesse segurável nos seguros de pessoas, limitando-se a exigir o consentimento por escrito do segurado, quando o seguro é realizado por um terceiro.

São considerados seguros de pessoas, todos aqueles em que o objeto do interesse é a própria pessoa humana - vida, integridade física e mental. O que se altera, nos diversos ramos de seguros de pessoas, é o risco: a morte natural, a morte acidental, os acidentes de invalidez e a própria sobrevivência ${ }^{155}$.

Todavia, há seguros de pessoas que se submetem ao regime do seguro de dano. São exemplos o seguro-saúde e o seguro-funeral, conforme previsão expressa do art. 802 do Código Civil ${ }^{156}$. Nesses casos, o objeto do interesse é o próprio patrimônio e não a vida e a integridade física. A morte e os eventos que atingem a saúde são os riscos que podem gerar uma despesa que atinge o patrimônio do segurado, cuja integridade busca proteger com o seguro $^{157}$.

\footnotetext{
${ }^{152}$ Art. L-132-2 da Lei francesa: "L'assurance em cas de décès contractée par um tiers sur la tête de l'assyré est nulle, si ce dernier n'y a pas donné son consentement oar écrit 'avec indication du capital ou de la rente initialement garantis'.

Le consentement de l'assuré doit, à peine de nullité, être donné par écrit, pour toute cession ou constitution de gage et pour transfert du bénéfice du contrat souscrit sus sa tête par un tiers.

Les dispositions du premier alinéa ne sont pas applicables aux contrats d'assurance de groupe à adhésion obligatoire.

${ }^{153}$ Art. 1919 da Lei italiana: "L'assicurazione può essere stipulata sulla vita propria o su quella di un terzo. L'assicurazione contratta per il caso di morte di un terzo non è valida se questi o il suo legale rappresentante non dà il consenso alla conclusione del contratto. Il consenso deve essere provato per iscritto."

${ }^{154} \S 150$ (2) da Lei alemã sobre Seguros (Versicherungsvertragsgesetz): (1) Die Lebensversicherung kann auf die Person des Versicherungsnehmers oder eines anderen genommen werden.

(2) Wird die Versicherung für den Fall des Todes eines anderen genommen und übersteigt die vereinbarte Leistung den Betrag der gewöhnlichen Beerdigungskosten, ist zur Wirksamkeit des Vertrags die schriftliche Einwilligung des anderen erforderlich; dies gilt nicht bei Kollektivlebensversicherungen im Bereich der betrieblichen Altersversorgung. Ist der andere geschäftsunfähig oder in der Geschäftsfähigkeit beschränkt oder ist für ihn ein Betreuer bestellt und steht die Vertretung in den seine Person betreffenden Angelegenheiten dem Versicherungsnehmer zu, kann dieser den anderen bei der Erteilung der Einwilligung nicht vertreten. [...]

${ }^{155}$ Nesse sentido: "Fra le assicurazioni di persone infine vanno inclusi tutti i contratti in cui il bene tutelato è la stessa persona umana, sia che ci si voglia garantire contro un evento fortuito, che riduce le nostre possibilità di lavoro o provoca la nuestra morte, sia che ci si voglia garantire contra il rischio della morte $\mathrm{o}$ della sopravivenza" (BUTTARO, Luca. L'interesse nell'assicurazione, p. 242).

${ }^{156} \mathrm{O}$ dispositivo em comento tem a seguinte redação: "Não se compreende nas disposições desta Seção a garantia do reembolso de despesas hospitalares ou de tratamento médico, nem o custeio das despesas de luto e de funeral do segurado.".

${ }^{157}$ Buttaro, tratando do seguro-funeral, explica: "Innanzitutto non è detto che si debba parlare di assicurazioni di persone tutte le volte che la possibilità che si verifichi un sinistro è legata ad un avvenimento della vita umana [...] Solo per queste [assicurazione dell spese funerale] infatti si potrá dire che la morte é le evento provocatore del danno, il quale non è però constituito dalla stessa perdita della vita umana, mas dalla somma che il patrimonio dell'assicurato o dei suoi eredi dovrebbe spender per le esequie. É in vista di questa diminuizione patrimoniale che l'assicurato conclude il contratto di assicurazione el il patrimonio di constui costituisce l'oggeto della tutela assicurativa." (BUTTARO, Luca, op. cit., p. 237-238).
} 
São também exemplos os seguros pessoais para garantia de obrigações, como aqueles inseridos nos contratos de empréstimos. Nessas hipóteses, em que pese o interesse fazer referência igualmente à vida ou à integridade física ou mental, relativamente aos mesmos riscos de morte e/ou invalidez, há aplicação do princípio indenitário, pois cabe à seguradora indenizar o dano efetivamente sofrido, de acordo com os limites estabelecidos contratualmente.

Há ainda outros seguros de pessoas, com função indenizatória, ainda que sem aplicação do princípio indenitário, como é o caso dos seguros sobre a vida de outrem, dos seguro de acidentes pessoais e do seguro por diárias de incapacidade temporária oriunda de acidente ou doença ${ }^{158}$ e os seguros de sobrevivência ${ }^{159}$.

Nesses casos, o bem objeto do interesse é, indiretamente, o próprio patrimônio. De fato, em que pese o bem objeto do interesse segurável ser a pessoa humana, a finalidade é de compensação, de previdência ${ }^{160}$, ou seja, de proteção contra os efeitos das adversidades da vida - incluindo as consequências da sobrevivência após determinada idade - e da morte certa, ainda que incerta no tocante à sua data. Não se confunde, porém, com a típica função indenizatória presente no seguro de dano. Daí por que o legislador, ao tratar da prestação da seguradora após a ocorrência do sinistro, refere-se à indenização no seguro de dano e ao capital no seguro de pessoas ${ }^{161}$.

Conforme assinalado, as subespécies de seguro de pessoas não se diferenciam relativamente ao bem, mas sim no que alude ao risco. De modo geral, pode-se dizer que, no seguro de vida, o bem objeto do interesse é a vida e o risco é o de morte por qualquer causa; no seguro de sobrevivência, o risco é a duração da vida humana após determinada idade, quando há uma expecativa de que diminua ou cesse a capacidade laboral; no seguro de acidentes pessoais, o bem é igualmente a vida, mas o risco é de morte por acidente, entendido como o evento exclusivo, súbito, violento, involuntário e externo ${ }^{162}$; no seguro

\footnotetext{
${ }^{158}$ Nesse sentido, TZIRULNIK, Ernesto; CAVALCANTI, Flávio de Queiroz B.; PIMENTEL, Ayrton. $O$ contrato de seguro de acordo com o novo Código Civil brasileiro, p. 152.

${ }^{159}$ Porque nesse caso, apesar do sinistro não constituir um dano à vida ou à integridade física do segurado pois o sinistro se caracteriza justamente pelo evento do segurado sobreviver a uma determinada idade -, presume-se a diminuição patrimonial inerente à velhice, fase em que a capacidade laborativa diminui ou cessa.

${ }^{160}$ Nesse sentido: FRANCO, Vera Helena de Mello. Contratos no direito privado: direito civil e empresarial, p. 320 .

${ }_{161}^{16}$ TZIRULNIK, Ernesto; CAVALCANTI, Flávio de Queiroz B.; PIMENTEL, Ayrton, op. cit., p. 152.

${ }^{162}$ Conforme definição constante, da Resolução CNSP n. 117/2004: “Art. 5ํㅡㄹ Considerar-se-ão, para efeitos desta Resolução, os conceitos abaixo:

I - acidente pessoal: o evento com data caracterizada, exclusivo e diretamente externo, súbito, involuntário, violento, e causador de lesão física, que, por si só e independente de toda e qualquer outra causa, tenha como
} 
de invalidez, o bem é a integraidade física e/ou mental da pessoa humana e o risco é invalidez por doença ou por acidente.

\subsubsection{A relação}

A relação é o vínculo que liga o sujeito ao bem. Discute-se na doutrina se o fato constitutivo da relação há de ser estritamente jurídico (real ou obrigacional) ou se basta uma relação de fato. Também não há consenso sobre o seu conteúdo: se estritamente econômico ou também moral.

\subsubsection{Fato constitutivo da relação}

Na doutrina de Ferrarini, aplicável exclusivamente ao seguro de dano, a relação entre uma pessoa e um bem pode ser tanto uma relação jurídica, cujo fato jurídico constitutivo - seja um direito real, ou obrigacional como uma relação de fato ${ }^{163}$. O essencial, diz o autor, é que a pessoa sofra um dano em consequência do sinistro ${ }^{164}$.

Na mesma trilha de Ferrarini ${ }^{165}$ é o posicionamento do argentino Halperin ${ }^{166}$ e do

conseqüência direta a morte, ou a invalidez permanente, total ou parcial, do segurado, ou que torne necessário tratamento médico [...]".

${ }^{163}$ Sobre a diferença entre relações jurídicas e relações de fato, explica Amaral: "As relações jurídicas são conseqüências dos fatos jurídicos, nascem em função do dispositivo da norma jurídica, depois do enquadramento do fato da vida real na hipótese de aplicação da norma. A vida social é, porém, fertilíssima na diversidade dos fatos, suscitando, por vezes, situações que não se enquadram na hipótese das normas jurídicas, não obstante os atributos da abstração. Isso faz com que diversos fatos, socialmente relevantes, não produzam efeitos jurídicos típicos por não corresponderem à hipótese de aplicação da normal, ou pela própria inexistência de norma jurídica adequada, embora já sejam socialmente valorados. Existe o fato, o valor, mas não a norma jurídica, o que não impede que a relação de fato produza, verificados certos pressupostos, os mesmos efeitos da relação de direito. Configura-se aqui a questão da eficácia jurídica da relação de fato" (AMARAL, Francisco. Direito Civil: introdução. 6. ed. rev., atual. e aum. Rio de Janeiro: Renovar, 2006. p. 179).

${ }^{164}$ FERRARINI, Sergio. L'interesse nell'assicurazioni, p. 30.

${ }^{165}$ Ibidem.

${ }^{166}$ HALPERIN, Isaac. El contrato de seguro, p. 432. 
espanhol Garrigues ${ }^{167}$, destacando que as classes de relação sobre o bem são múltiplas, podem ser reais ou creditórias, mas não é necessário que sejam jurídicas, pois também a relação de fato pode gerar um interesse segurável.

Já Mello Franco invoca doutrina do direito americano ${ }^{168}$, segundo a qual, apenas o direito real ou obrigacional é que pode ensejar a relação a que se reporta o interesse ${ }^{169}$. Moitinho de Almeida também entende necessário que o fato constitutivo da relação seja de ordem jurídica e que vise à satisfação das necessidades de seu titular ${ }^{170}$. Medina, por sua vez, reporta-se a Vivante para asseverar que o interesse segurável somente pode nascer da propriedade da posse e do contrato ${ }^{171}$. Trata-se de posicionamentos relativos ao seguro de dano.

O fato constitutivo da relação no seguro de pessoas não é explorado na doutrina. Não se questiona da relação no seguro sobre a própria vida, mas a indagação surge no seguro sobre a vida de terceiro. Nesse caso, a relação pode ser conjugal, de parentesco ou mesmo de fato, como é o caso da união estável. Pode, ainda, ser fruto de um vínculo obrigacional, como se dá no seguro prestamista, no qual o credor contrata uma garantia sobre a vida do devedor, até o limite do crédito concedido.

Tzirulnik, Cavalcanti e Pimentel não chegam a abordar o fato constitutivo da relação, mas preconizam a necessidade de que ela seja juridicamente relevante, ou seja, há de ser protegida pela ordem jurídica. A mesma posição é defendida por Carvalhaes Ribeiro ao destacar que nem todo interesse é segurável, pois apenas aqueles amparados juridicamente podem ser objeto do contrato de seguro ${ }^{172}$.

\footnotetext{
${ }^{167}$ GARRIGUES, Joaquim. Algunas ideas sobre el interés en el seguro contra danos. In: ASSOCIAZIONE INTERNATIONALE DI DIRITTO DELLE ASSICURAZIONI - AIDA. Studi in onore di Antigono Donati, v. I, p. 176.

${ }^{168}$ A autora cita o artigo de Cwinya-ai, nos seguintes termos: "The nature of insurable interest can thus be, briefly, understood by the following points: (a) The interest should not be a bare sentimental or emotional right or interest; (b) it should be a right in a property or a right arising from a contract made in respect of that property; (c) The interest must be pecuniary; mere inconvenience or disadvantage cannot be regarded as an insurable interest; (d) the interest should be lawful, and must not be illegal, immoral or opposed to public policy" (CWINYA-AI, Robert Ongon. What is necessary of insurable interest in insurance contracts? New Orleans, 2008. Disponível em: < http://ssrn.com/abstract=1407578>. Acesso em: 15 jan. 2011).

${ }^{169}$ FRANCO, Vera Helena de Mello, Contratos no direito privado: direito civil e empresarial, p. 290.

170 "É preciso que o interesse se reporte a uma pessoa ou pessoas a quem juridicamente certo bem seja ou possa vir a ser afecto à satisfação das suas necessidades." (ALMEIDA, J. C. Moitinho de. O contrato de seguro no Direito Português e Comparado Lisboa: Sá da Costa, 1971. p. 148).

${ }^{171}$ MAGALLANES, Pablo Medina. O interesse segurável. In: III FÓRUM DE DIREITO DO SEGURO "JOSÉ SOLLERO FILHO", p. 378.

${ }^{172}$ RIBEIRO, Amadeu Carvalhaes. Direito de seguros: resseguro, seguro direto e distribuição de serviços. São Paulo: Atlas, 2006. p. 60-61.
} 
É possível concluir, portanto, que a relação pode ser tanto jurídica como de fato, mas sempre socialmente relevante e protegida pela ordem jurídica. Assim, de um lado, garante-se que não será qualquer relação que poderá dar ensejo a um interesse segurável, e, de outro, que as relações de fato, socialmente valoradas e reconhecidas, também sejam aptas a caracterizar o interesse segurável.

Seja qual for o seu conteúdo, a relação deve estar claramente fixada no contrato, a fim de possibilitar a correta delimitação do risco pelo segurador ${ }^{173}$.

A questão se relaciona com a concepção subjetiva ou objetiva do interesse.

Ferrarini rechaça o posicionamento doutrinário, ao qual chama de inútil e danoso, que busca uma concepção objetiva do interesse, ou seja, do interesse incorporado ao bem segurado, existente independentemente de qualquer interessado ${ }^{174}$.

A ideia de interesse objetivo foi sustentada, em particular, nos seguros "por conta de quem pertencer" ${ }^{175}$ e também em razão das normas legais, segundo as quais, salvo estipulação em contrário, a alienação da coisa segurada transfere ao adquirente as obrigações e os direitos decorrentes do contrato de seguro ${ }^{176}$.

Mas, conforme ressalta Ferrarini, no seguro "por conta de quem pertencer", o fato de se desconhecer quem será o titular do interesse no momento do sinistro não se confunde com um interesse objetivamente considerado. Também nessa subespécie de seguro, é necessário que estejam determinados na conclusão do contrato, o bem, a espécie de relação existente entre o bem e o sujeito, com a única diferença de que permanece desconhecido o sujeito concretamente interessado, que pode competir a quem contratou o seguro ou a um terceiro que esteja no polo daquela relação.

\footnotetext{
${ }^{173}$ Nesse sentido: FERRARINI, Sergio. L'interesse nell'assicurazione, p. 31.

${ }^{174}$ Ibidem, p. 31.

${ }^{175}$ Conforme explica Mello Franco, o seguro "por conta de quem pertencer" é uma subespécie do seguro "por conta alheia" ou "por conta de terceiro". Esse tipo de seguro caracteriza-se pela indeterminação do beneficiário da indenização (FRANCO, Vera Helena de Mello. Contratos no Direito Privado: direito civil e empresarial, p. 311.

176 No Código Civil de 1916, havia a seguinte previsão: "Art. 1.463. O direito à indenização pode ser transmitido a terceiro como acessório da propriedade, ou de direito real sobre a coisa segura. Já o Código Civil de 2002 prevê: “Art. 785. Salvo disposição em contrário, admite-se a transferência do contrato a terceiro com a alienação ou cessão do interesse segurado”. A questão será abordada em tópico próprio, no capítulo 4 relativo ao interesse no seguro de dano.
} 


\subsubsection{Interesse econômico versus moral}

A divergência sobre o conteúdo econômico ou moral do interesse relaciona-se exclusivamente ao seguro de pessoas. No seguro de danos, o conteúdo da relação há de ser necessariamente de índole econômica. Trata-se de uma decorrência lógica da própria aplicação do princípio indenitário, segundo o qual a importância segurada ou o limite da garantia não pode ultrapassar o valor do interesse segurado, conforme dicção do próprio art. 778 do Código Civil ${ }^{177}$.

Daí por que, para os doutrinadores que exigem o interesse segurável, nos seguros de dano há menção apenas ao cunho econômico da relação. Halperin ${ }^{178}$ e Ferrarini ${ }^{179}$ expressam opinião nesse sentido. Mas, mesmo entre aqueles que reconhecem o interesse segurável como elemento presente também nos seguros de pessoas, há controvérsia se, também nesse caso, o interesse pode ser de cunho exclusivamente moral.

A discussão adquire relevância no seguro sobre a vida de um terceiro, uma vez que o interesse na preservação da própria vida já se presume ${ }^{180}$. O caput do art. 790 exige, todavia, expressamente, a obrigação do proponente de declarar, sob pena de falsidade, o seu interesse pela preservação da vida do segurado.

Parte expressiva da doutrina entende que a relação estabelecida entre o sujeito e o bem, quer no seguro de dano, quer no seguro de pessoas, deve ser de natureza econômica, ou seja, a ocorrência do sinistro deve significar para o segurado uma perda patrimonial, não bastando o simples sofrimento moral. É nesse sentido a opinião de Stiglitz $^{181}$, na Argentina, e de Mello Franco ${ }^{182}$ e Delgado $^{183}$, no Brasil.

Já Tzirulnik, Cavalcanti e Pimentel adotam uma posição intermediária, ressaltando que, diante da ausência do adjetivo econômico ao interesse no conceito do art. 757 ,

\footnotetext{
177 “Art. 778. Nos seguros de dano, a garantia prometida não pode ultrapassar o valor do interesse segurado no momento da conclusão do contrato, sob pena do disposto no art. 766, e sem prejuízo da ação pena que no caso couber."

${ }^{178}$ HALPERIN, Isaac. El contrato de seguro, p. 431.

${ }^{179}$ FERRARINI, Sergio. L'interesse nell'assicurazione, p. 36.

${ }^{180}$ Conforme Tzirulnik, Cavalcanti e Pimentel, no seguro sobre a própria vida, o interesse "resta como que esmaecido, caracterizando, no mais das vezes, o animus donandi (TZIRULNIK, Ernesto; CAVALCANTI, Flávio de Queiroz B.; PIMENTEL, Ayrton. O contrato de seguro de acordo com o novo Código Civil brasileiro, p. 162).

${ }^{181}$ STIGLITZ, Rubén S. Derecho de seguros. Buenos Aires: Abeledo-Perrot, 2001. v. I, p. 274.

${ }^{182}$ FRANCO, Vera Helena de Mello, Contratos no Direito Privado: direito civil e empresarial, p. $290-291$.

${ }^{183}$ DELGADO, José Augusto. Comentários ao novo Código Civil. Rio de Janeiro: Forense, 2004. p. 726-727.
} 
"poderá ele, em determinados casos, nos seguros de pessoas, ser apenas moral" "184. De fato, ao teor do parágrafo único do art. 790 do Código Civil de 2002, o interesse presumido entre ascendentes, descendentes e cônjuges não é necessariamente de caráter econômico, já que a lei não fez aqui qualquer distinção. Previu apenas que, "até prova em contrário, presume-se o interesse, quando o segurado é cônjuge, ascendente ou descendente do proponente". Trata-se, segundo esses autores, de uma presunção de afetividade, presunção essa relativa, já que a própria lei admite "prova em contrário" 185.

Em posição divergente, Delgado apregoa que, mesmo no parágrafo único do art. 790, a presunção legal refere-se ao interesse econômico. Na lição do autor, o interesse deve ser sempre claro e preciso, revestindo-se de natureza material ${ }^{186}$. De toda maneira, para

Tzirulnik, Cavalcanti e Pimentel, a possibilidade da existência de mero interesse moral se limitaria a tal previsão legal, cujo rol é taxativo. Em qualquer outro seguro sobre a vida de um terceiro, o interesse exigido há de ter natureza econômica, não se admitindo aquele meramente afetivo. Denota ser essa, de fato, a melhor solução, tendo em vista a dificuldade de se demonstrar o interesse meramente afetivo.

O direito inglês é ainda mais restritivo. A exigência do interesse é prevista no Life Assurance Act $1774^{187}$, que também não faz menção à sua natureza econômica ou afetiva. A jurisprudência, porém, fixou o entendimento no sentido de que o interesse afetivo se restringe ao seguro sobre a própria vida e ao seguro do cônjuge ${ }^{188}$, vedando expressamente o seguro nas relações de parentesco, inclusive entre pais e filhos ${ }^{189}$, em razão do entendimento de que é insuficiente o interesse meramente afetivo, quando ausente uma obrigação legal de assistência econômica entre parentes.

Nos Estados Unidos, de modo diverso, conforme salientado, a decisão proferida no caso Corson's vs. App, julgado em 1886 na Pensilvânia, reconheceu que o interesse segurável não era necessariamente pecuniário, admitindo-se o interesse de afeição -

\footnotetext{
${ }^{184}$ TZIRULNIK, Ernesto; CAVALCANTI, Flávio de Queiroz B.; PIMENTEL, Ayrton. O contrato de seguro de acordo com o novo Código Civil brasileiro, p. 153.

${ }^{185}$ Ibidem, p. 165.

${ }^{186}$ DELGADO, José Augusto. Comentários ao novo Código Civil, p. 727.

${ }^{187}$ Life Assurance Act 1774: “[...] 1. From and after the passing of this Act no insurance shall be made by any person or persons, bodies politick or corporate, on the life or lives of any person, or persons, or on any other event or events whatsoever, wherein the person or persons for whose use, benefit, or on whose account such policy or policies shall be made, shall have no interest, or by way of gaming or wagering; and every assurance made contrary to the true intent and meaning hereof shall be null and void to all intents and purposes whatsoever".

${ }_{188}$ Nesse sentido: Griffiths x Fleming [1909] 1 KB 805 e Reed x Royal Exchange Assurance Co (1795).

${ }^{189}$ Halford x Kymer (1830) 10 B\&C 724.
} 
principalmente, mas não só -, nas relações de parentesco e entre marido e mulher. A decisão ressalta que em todos os casos deve haver um motivo razoável, fundado sobre as relações das partes entre si, quer pecuniários, quer de parentesco sanguíneo ou não, de que algum benefício ou vantagem decorra da continuidade da vida do segurado.

A legislação francesa, conforme observado neste trabalho, não exige a comprovação do interesse segurável no seguro sobre a vida de outrem, mas apenas o consentimento daquele, sobre cuja vida quer se contratar o seguro. A mesma solução é adotada pela lei italiana e alemã, sofrendo críticas da doutrina que defende não ser o simples consentimento suficiente para evitar que o seguro se transforme em uma aposta.

\subsection{A exposição da relação ao risco}

Reitera-se que, de acordo com a posição majoritária, o interesse como relação entre uma pessoa e um bem existe independentemente de um risco que o ameace; todavia, o interesse somente será segurável quando ameaçado por um risco. Por isso, o risco não é uma premissa de existência do interesse, mas uma condição de sua assegurabilidade ${ }^{190}$.

As diversas teorias acerca do contrato de seguro refletem também na definição de risco.

Nas suas primeiras formulações, cujo aplicação se restringe ao seguro de dano, risco é a possibilidade de um evento danoso ${ }^{191}$. Segundo Ferrarini ${ }^{192}$, adepto da Teoria da Necessidade, risco é "o evento capaz de provocar um desequilíbrio desfavorável entre as necessidades de um indivíduo e os meios disponíveis à sua satisfação, ou seja, o risco deve ser capaz de fazer surgir uma necessidade".

O conceito foi aperfeiçoado pela Teoria da Transferência do Risco, que considera risco "como a possibilidade de um evento futuro e incerto, tanto capaz de afectar coisas,

\footnotetext{
${ }^{190}$ Nesse sentido: "É certo, como salienta Donati, que a sujeição ao risco é estranha ao conceito técnico de interesse, embora exista uma interdependência na medida em que 'um interesse não é segurável se não for sujeito a risco, assim como um risco não pode ser segurado se não existe um interesse'. Mas sempre se poderá dizer que, no âmbito do direito dos seguros, só releva aquele interesse sujeito a risco, constituindo, assim, este, não um elemento do conceito de interesse, mas um seu limite." (ALMEIDA, J. C. Moitinho de. O contrato de seguro no Direito Português e Comparado, p. 147-148).

${ }^{191}$ Cf. ALVIM, Pedro. O contrato de seguro, p. 314-315.

${ }^{192}$ FERRARINI, Sergio. L'interesse nell'assicurazione, p. 42.
} 
em cuja conservação o segurado se interessa, como de obstacular a formação de determinados capitais, tratando-se de acontecimento relativo à vida humana"193.

Na contemporaneidade, risco é definido como a possibilidade de ocorrência de um evento pré-determinado, capaz de lesar o interesse garantido ${ }^{194}$.

O risco tanto pode consistir em um evento capaz de afetar o bem, objeto da relação, quanto em um evento capaz de extinguir ou reduzir a relação entre a pessoa e o bem, ainda que sem atingir o bem propriamente dito. No seguro de danos, exemplos de risco, no primeiro caso, são aqueles de incêndio, de furto, de insolvência, de responsabilidade civil e, no segundo, os riscos de atraso e de improdutividade da empresa. No seguro de pessoas, o risco incide sempre sobre o bem (a pessoa humana) e não sobre a relação.

Conforme apontado, para que o contrato gere efeitos, é necessário que esteja determinado não só o interesse, mas também o risco. A apólice deve trazer a clara determinação e delimitação dos riscos; portanto, a garantia securitária não incide sobre todos os riscos a que o interesse está sujeito, mas tão somente sobre aqueles expressamente pré-determinados na apólice. A previsão dos riscos exige não apenas a previsão dos elementos relativos a cada espécie de risco, mas também a todos os elementos fixados pelas partes, como período de vigência, condições para manifestação do risco e grau de intensidade.

$\mathrm{O}$ risco pode constituir um evento individualmente determinado, como por exemplo, o incêndio de uma casa por curto circuito. Em regra, porém, o seguro é realizado prevendo diversos eventos da mesma espécie. Nesse caso, o risco é indicado pelas características gerais de determinada categoria de eventos; por exemplo, os eventos naturais para os riscos de incêndio, os eventos de direito para o risco de responsabilidade, os eventos de economia para o risco de lucros cessantes, os eventos naturais ou acidentais para o risco de morte.

Considerando a independência entre risco e interesse, a cessação do risco não afeta o interesse, mas extingue sua assegurabilidade e, por isso, inviabiliza o contrato $^{195}$. Já a

\footnotetext{
193 ALMEIDA, J. C. Moitinho de. O contrato de seguro no Direito Português e Comparado, p. 18.

194 TZIRULNIK, Ernesto; CAVALCANTI, Flávio de Queiroz B.; PIMENTEL, Ayrton. O contrato de seguro de acordo com o novo Código Civil brasileiro, p. 36,

${ }^{195}$ Daí a previsão expressa do art. 773 do Código Civil brasileiro: "O segurador que, ao tempo do contrato, sabe estar passado o risco de que o segurado se pretende cobrir, e, não obstante, expede a apólice, pagará em dobro o prêmio estipulado." Conforme adverte Tzirulnik, o artigo em comento refere-se ao risco passado (ocorrido), não ao risco inexistente (ibidem, p. 94), em everdade é de pouca aplicação prática, tendo em vista que, atualmente, a transmissão de informações é quase instantânea (ALVIM, Pedro. O seguro e o novo
} 
cessação do interesse elimina o risco, pois este somente pode incidir sobre o interesse existente $^{196}$.

As causas atinentes ao risco passíveis de diminuição do interesse segurável podem ser agrupadas em três categorias, de acordo com o elemento do interesse afetado: 1) o bem, objeto da relação - por exemplo, um proprietário de casas segurou-as contra o risco de incêndio e essas são destruídas por um terremoto; um proprietário segurou o automóvel contra o risco de furto, e esse foi destruído por causa de um incêndio; um agricultor assegurou o produto das suas parreiras contra o risco de uma tempestade, e essas são atingidas por uma peste; 2) a relação entre a pessoa e o bem - que pode, por exemplo, mudar de espécie, como no caso de um comerciante que tenha contratado um seguro de mercadorias como proprietário e depois as vende, conservando-as, porém, consigo na qualidade de depositário; e 3) o sujeito da relação - por exemplo, no caso de alienação do bem assegurado ou naquele de morte do segurado ${ }^{197}$.

Na hipótese de o interesse recair sobre um patrimônio, entendido como um todo único e indivisível, no entanto, não se pode falar em cessação do interesse segurável pela diminuição do bem ou pela alteração de sua titularidade. Os exemplos são os seguros de responsabilidade civil de um automóvel. No caso da venda do automóvel, cessa o risco e não o interesse, pois o bem objeto da relação aqui é o patrimônio do segurado e não o automóvel.

\subsection{O significado de interesse legítimo}

As controvérsias acerca do conteúdo da relação e de sua exposição ao risco relacionam-se com a qualidade de legítimo exigida pelo legislador brasileiro no art. 757 do Código Civil.

Legítimo, derivado justamente do vocábulo latino Lex, exprime uma noção de licitude, ou seja, aquilo que está em conformidade com a lei, permitido ou autorizado por

Código Civil, p. 76), mas serve para ilustrar a impossibilidade de se garantir um interesse legítimo, se não há exposição ao risco.

${ }^{196}$ FERRARINI, Sergio. L'interesse nell'assicurazione, p. 44.

${ }^{197}$ Ibidem, p. 45. 
lei ou ainda amparado ou apoiado em lei ${ }^{198}$. No direito processual, interesse legítimo relaciona-se à titularidade da pretensão, mais especificamente, se quem pede a tutela jurisdicional é efetivamente o titular do interesse ${ }^{199}$.

O significado da expressão interesse legítimo, em sua concepção securitária, é pouco explorado na doutrina brasileira.

Como antes referido, para Tzirulnik, Cavalcanti e Pimentel, o termo legítimo tem por objetivo enfatizar a pertinência da relação entre o sujeito e o bem, a fim de que reste demonstrado o real interesse na sua preservação e a desvantagem decorrente de eventual sinistro $^{200}$. Segundo esses autores, "parece evidente a admissão do seguro apenas quando o segurado estiver em relação potencial com o efeito da lesão, tendo-lhe proveito a garantia"201.

Mello Franco, na mesma trilha, ressalta que legítimo não se refere propriamente à licitude, mas sim à ideia de que "o segurado deve estar interessado em que o sinistro não ocorra, e não outra coisa", e que exprime uma noção de titularidade, pois o "interesse deve ser próprio e não alheio,"202.

Halperin, por sua vez, entende que a legitimidade se refere à exigência de licitude e observação dos bons costumes, já que o risco sempre será segurável; eventual ilegalidade ou imoralidade resulta do interesse; assim, o interesse será ilegítimo se envolver uma proibição legal ou quando for contrário aos bons costumes ${ }^{203}$.

Legítimo não exprime, de fato, apenas a noção de licitude ou conformidade à lei. Fosse apenas esse seu significado, a inclusão do termo pelo legislador brasileiro seria até mesmo desnecessária, já que, na qualidade de objeto do contrato de seguro, o interesse segurável submete-se aos requisitos previstos no art. 104, inc. II, do Código Civil, ou seja, deve ser lícito, possível, determinado ou determinável.

O Código de Comércio chileno requer, no art. 518, além da capacidade legal, a existência de um interesse real de evitar os riscos pelo segurado:

\footnotetext{
${ }^{198}$ SILVA, De Plácido e. Vocabulario jurídico, p. 61, v. III.

${ }^{199}$ Cf. MARQUES, José Frederico. Manual de Direito Processual Civil, p. 158-159.

200 TZIRULNIK, Ernesto; CAVALCANTI, Flávio de Queiroz B.; PIMENTEL, Ayrton. O contrato de seguro de acordo com o novo Código Civil brasileiro, p. 32.

${ }^{201}$ Ibidem, p. 33.

${ }^{202}$ FRANCO, Vera Helena de Mello, Contratos no Direito Privado: direito civil e empresarial, p. 291.

203 "El interés asegurable debe ser legítimo [...] El riesgo es asegurable y los hechos en sí no violan la ley; la ilegalidad o inmoralidad resulta del interés, así en el seguro contra incendio de cosas para el juego prohibido o del buque destinado al contrabando. Es ilegítimo cuando influye una prohibición legal o es contrario a las buenas costumbres [...]" (HALPERIN, Isaac. El contrato de seguro, p. 435).
} 
"Podem celebrar um seguro todas as pessoas capazes de obrigar-se. Mas, do segurado, requer-se, além da capacidade legal, que tenha ao tempo do contrato um interesse real em evitar os riscos, seja na qualidade de proprietário, co-partícipe, fideicomissário, usufrutuário, arrendatário, credor ou administrador de bens alheios, seja em qualquer outra que o constitua interesse na conservação do objeto segurado",204.

Depreende-se da legislação chilena que há uma presunção de interesse nos casos em que o vínculo do sujeito com o objeto decorra de uma relação de propriedade, usufruto, crédito, administrador, entre outras; mas nelas não se esgota, sendo admissível qualquer relação que demonstre a existência de um interesse real do segurado na conservação do objeto segurado.

Por real, segundo Vivante, citado por Medina ${ }^{205}$, deve ser compreendido um direito efetivo, presente, em contraposição à mera expectativa de futuro benefício.

Entende-se, assim, que o termo legítimo, empregado para qualificar o interesse, visa assegurar a contratação dos seguros apenas por pessoas legitimadas para tanto. Ou seja, por aquelas que possuam uma relação juridicamente protegida com o bem, que autoriza a contratação do seguro, porque dela decorre o fato de que a perda do bem segurado causa dano efetivo ao próprio segurado que, por isso, tem interesse na sua conservação e, por consequência, na contratação da proteção securitária.

Conforme adverte Carvalhaes Ribeiro, na mesma linha de Tzirulnik, Cavalcanti e Pimentel, bem como de Mello Franco:

\section{“[...] o principal fundamento para distinguir entre o interesse juridicamente relevante e aquele não relevante é o de evitar que o seguro se torne um negócio especulativo. Essa é, aliás, a origem do 'insurable interest doctrine' na Inglaterra e nos EUA. Se fosse dado}

\footnotetext{
${ }^{204}$ Texto original do art. 518: "Pueden celebrar un seguro todas las personas hábiles para obligarse. Pero de parte del asegurado se requiere, además de la capacidad legal, que tenga al tiempo del contrato un interés real en evitar los riesgos, sea en calidad de propietario, copartícipe, fideicomisario, usufructuario, arrendatario, acreedor o administrador de bienes ajenos, sea en cualquiera otra que lo constituya interesado en la conservación del objeto asegurado.

El seguro en que falte este interés es nulo y de ningún valor.".

${ }^{205}$ MAGALLANES, Pablo Medina. O interesse segurável. In: III FÓRUM DE DIREITO DO SEGURO "JOSÉ SOLLERO FILHO”, p. 378.
} 
a qualquer um segurar qualquer tipo de interesse -próprio ou não, jurídico ou não -, pessoas poderiam contratar seguro de coisas em relação às quais não têm nenhum interesse legítimo. [...] Para os segurados 'não legitimados' a ocorrência de sinistros passaria a ser algo desejado",206.

Exemplo concreto de severos males decorrentes da falta de interesse legítimo é a própria crise financeira deflagrada nos Estados Unidos em 2008. Embora os derivativos de crédito (Credit Default Swaps - CDS) na base da crise não sejam juridicamente "contratos de seguro", servem ao mesmo fim econômico, pois objetivam, em última análise, segurar determinado risco de crédito. É nesse sentido que o comprador do CDS (equivalente ao segurado) adquire do vendedor (segurador, se seguro fosse) proteção contra o risco de inadimplência (falência ou outro) de determinada empresa, por exemplo.

Não obstante, e diferentemente do seguro, o CDS esteve completamente à margem da regulação do sistema financeiro dos Estados Unidos, bancário ou securitário, pemitindo assim que fosse amplamente contratatado em transações, nas quais o comprador não tinha exposição direta ao risco. Nessa toada, parte significativa do crescimento desse mercado (de US\$ 62 trilhões em 2007) ${ }^{207}$ esteve diretamente associada à não exigência de interesse legítimo para a contratação, o que deixava as partes livres para especularem sobre as tendências de risco envolvendo o crédito e resultou em que $80 \%$ dos CDS fossem historicamente sem exposição ao risco ${ }^{208}$. A proliferação desmesurada e desregulada desse mercado é um dos motivos centrais da disseminação sistêmica do risco que culminou com a quebra ou socorro de diversas instituições financeiras nos Estados Unidos e no mundo, gerando uma crise cujos efeitos são sentidos até os dias atuais.

O risco de especulação que se visa impedir com a exigência do interesse segurável legítimo é o que se chama, nos países do Reino Unido, Estados Unidos e outros de commom law, de moral hazard, que é justamente o perigo de que a contratação do seguro gere no segurado um comportamento diferente daquele que teria se o seguro não existisse.

\footnotetext{
${ }^{206}$ RIBEIRO, Amadeu Carvalhaes. Direito de seguros: resseguro, seguro direto e distribuição de serviços, p. 60-61.

207 Cf. ISDA Publishes Year-End 2008 Market Survey. Disponível em: www.isda.org/press/ press042209market.html. Acesso em: 15 fev. 2010.

${ }^{208}$ É o que se chama de transação naked (cf. SHADAB, Houman B. Guilty by Association? Regulating Credit Default Swaps. Entrepreneurial Business Law Journal, p. 40. Disponível em: http://papers.ssrn.com/sol3/ papers.cfm?abstract_id=1368026>. Acesso em: 5 maio 2009.
} 
É esse desvio comportamental - que nos casos extremados incentiva a fraude, mas a ela não se limita - que se procura evitar com a exigência do interesse segurável legítimo e, nos seguros de dano, cumulativamente, com o princípio indenitário. 


\section{CAPÍTULO 3}

\section{INTERESSE SEGURÁVEL: NATUREZA JURÍDICA}

Os diferentes tratamentos legislativos para a figura do interesse segurável resultam em uma absoluta ausência de consenso sobre sua qualificação jurídica ${ }^{209}$.

Conforme Buttaro $^{210}$, para diversas legislações, o interesse é elemento essencial do contrato, por vezes considerado o próprio objeto do contrato de seguro. Em outros casos, como observado, o interesse segurável é elemento apenas do seguro de dano. Algumas legislações referem-se ao interesse como a causa do contrato, ao passo que outras, como pressuposto de validade.

De modo geral, verifica-se que o interesse ora constitui uma noção essencial do direito do seguro, ora uma noção limitada ao seguro de dano ${ }^{211}$.

A definição do papel do interesse é de extrema importância, na medida em que exige uma análise da própria estrutura do contrato de seguro ${ }^{212}$.

\footnotetext{
${ }^{209}$ Nesse sentido: "Il s'agira de déterminer si l'intérêt d'assurance constitue une notion essentielle du droit des assurances, comme le suggèrent certains droit étrangers, ou bien s'il n'est qu'une notion accessoire, secondaire et d'application limitée, comme l'envisagent le législateur frrançais et la majeure partie de la doctrine française." (PROVOST, Magalie. La notion d'intérêt d'assurance, p. 14). E, ainda: "De tudo quanto analisado, não há dúvida de que o interesse segurável é um elemento de enorme importância, ao menos no contrato de seguro. A doutrina, no entanto, não entrou em um consenso do significado do interesse segurável para os contratos de seguro" (MAGALLANES, Pablo Medina. O interesse segurável. In: III FÓRUM DE DIREITO DO SEGURO “JOSÉ SOLLERO FILHO”, p. 394).

${ }^{210}$ BUTTARO, Luca. L'interesse nell'assicurazione, p. 45.

${ }^{211}$ Nesse sentido: FERRARINI, Sergio. L'interesse nell'assicurazione, p. 1. (Tradução livre: "Nas leis, que regulam o seguro, diversos são os empregos dados ao conceito de interesse. De fato algumas, mais modernas, elevam o interesse ao conceito central da asseguração contra os danos, enquanto outras se ocupam somente do reflexo, para determinar quem pode contrair a asseguração ou beneficiar-se dela."). No mesmo sentido: PROVOST, Magalie, op. cit., p. 14.

${ }^{212}$ Buttaro faz uma crítica à indefinição legislativa, pois entende que definir o papel do interesse se refere à definição da própria estrutura do contrato, e isso não pode ser feito por disposição legislativa. Segundo o autor, o legislador deve apenas constatar a relevância do interesse, cabendo ao intérprete decidir a maneira como o interesse integrará o contrato e as consequências dele advindas (BUTTARO, Luca, op. cit., p. 46).
} 


\subsection{Os elementos do contrato de seguro na legislação brasileira}

Antonio Junqueira Azevedo entende que os elementos do negócio jurídico são tudo aquilo que compõe a sua existência no campo do direito. Os elementos classificam-se, conforme o grau de abstração, em elementos gerais, comuns a todos os negócios; elementos categoriais, próprios de cada tipo de negócio; e elementos particulares, existentes em um negócio determinado, sem serem comuns a todos os negócios ou certos tipos de negócio ${ }^{213,214}$.

Interessam, ao presente estudo, os elementos categoriais inderrogáveis que caracterizam o tipo do negócio e fixam o regime jurídico a que ele se submete, não podendo ser afastado pela vontade das partes.

Esses caracteres emergem da estrutura normativa de cada categoria de negócio. No caso do contrato de seguro ínsito na legislação brasileira, mais especificamente no caput do art. 757 do CC de $2002^{215}$, do qual se extraem os seguintes elementos categoriais inderrogáveis do contrato de seguro: prêmio, garantia, interesse e risco ${ }^{216,217}$.

213 AZEVEDO, Antonio Junqueira de. Negócio jurídico: existência, validade e eficácia. 3. ed. São Paulo: Saraiva, 2000. p. 31.

${ }^{214} \mathrm{Na}$ doutrina tradicional, os elementos dividem-se em: essenciais, naturais e acidentais; ou, ainda, essentialia negotii, naturalia negotii e accidentalia negotii. Conforme Monteiro, os elementos essenciais referem-se àqueles elementos imprescindíveis à estrutura do ato; os naturais, por sua vez, são aqueles inseridos no negócio jurídico pelo ordenamento, por meio de normas supletivas; e os acidentais são aqueles que se destinam a modificar algumas de suas condições naturais (BARROS MONTEIRO, Washington de. Curso de Direito Civil - parte geral. 15. ed. São Paulo: Saraiva, 1980. p. 184).

215 “Art. 757. Pelo contrato de seguro, o segurador se obriga, mediante o pagamento do prêmio, a garantir interesse legítimo do segurado, relativo a pessoa ou a coisa, contra riscos predeterminados.

Parágrafo único. Somente pode ser parte, no contrato de seguro, como segurador, entidade para tal fim legalmente autorizada."

216 Alguns autores consideram a empresarialidade prevista no parágrafo único do art. 757 também um elemento do contrato de seguro: "Somente pode ser parte, no contrato de seguro, como segurador, entidade para tal fim legalmente autorizada." A controvérsia será abordada adiante em tópico próprio.

${ }^{217}$ Importante ressaltar que o conceito de contrato de seguro previsto no Projeto de Lei n. 3.555/2004 mantém os mesmos elementos já apontados: "Art. 1ํㅡ. Pelo contrato de seguro, a seguradora se obriga, mediante um prêmio equivalente, a garantir interesse legítimo do segurado ou do beneficiário contra riscos predeterminados". A disposição prevista no parágrafo único do art. 757 do Código atual consta do art. 2ํำ do Projeto: "Só podem pactuar contratos de seguro empresas que se encontrem devidamente autorizadas na forma da lei e que tenham depositado junto ao órgão fiscalizador competente as condições contratuais e as respectivas notas técnicas e atuariais.". 


\subsubsection{Prêmio e garantia}

De acordo com o novo Código Civil brasileiro, os elementos prêmio e garantia configuram as prestações essenciais das partes ${ }^{218}$. A garantia é a prestação da seguradora e o prêmio a prestação do segurado, ou seja, o preço da garantia ${ }^{219}$.

Na concepção do contrato de seguro do Código Civil de $1916^{220}$, entendia-se que a prestação da seguradora era a indenização ${ }^{221}$, devida somente ao ocorrer o risco previsto no contrato (sinistro). Referido posicionamento segue defendido por parte da doutrina, a exemplo de Bechara, para quem o objetivo fim do seguro é indenizar o segurado ou pagar o capital ao beneficiário, tendo a garantia o papel apenas de conferir ao segurado uma "sensação de conforto". A garantia, assim, consiste apenas "no meio, para que o fim colimado, dependente de um acontecimento futuro e incerto, seja realizado" ${ }^{\text {222 }}$. Segundo Comparato, porém, ao subscrever uma apólice de seguro, “o segurado tem em vista não apenas uma soma em dinheiro correspondente à indenização, mas também a garantia da supressão do risco que pesa sobre si, em uma palavra, a segurança". Por isso, para o autor, a obrigação de segurador é de garantia, obrigação essa que se traduz no dever de prestar segurança $^{223}$. Na mesma esteira é a posição de Mello Franco ${ }^{224}$, que ressalta, porém, que o risco não se transfere nem é suprimido. A seguradora se limita a garantir uma compensação econômica em caso de eventual sinistro ${ }^{225}$.

\footnotetext{
${ }^{218}$ Referse-se, neste estudo, como prestações essenciais, porque a tais prestações se somam outros deveres e ônus, que não são objeto do presente estudo. Segundo Comparato, o pagamento do prêmio não é único dever do segurado, a quem incumbe também o dever de não agravar os riscos, de comunicar eventual agravação, de submeter-se à fiscalização da seguradora, de comunicar o sinistro, de salvamento para minorar o dano (COMPARATO, Fabio Konder. O seguro de crédito, p. 124). E Mello Franco ressalta que a prestação de garantia implica uma obrigação adicional, qual seja, a de adquirir e manter capacidade econômica para fazer frente aos riscos futuros, afastando a possibilidade da sua insolvência. Isso significa a obrigação de formar reservas (FRANCO, Vera Helena de Mello. Lições de direito securitário: seguros terrestres privados, p. 302$303)$.

${ }^{219}$ TZIRULNIK, Ernesto; CAVALCANTI, Flávio de Queiroz B.; PIMENTEL, Ayrton. O contrato de seguro de acordo com o novo Código Civil brasileiro, p. 38.

${ }^{220}$ Art. 1.432 do CC de 1916: "Considera-se o contrato de seguro aquele pelo qual uma das partes se obriga para com a outra, mediante a paga de um prêmio, a indenizá-la do prejuízo resultante de riscos futuros previstos no contrato.".

${ }^{221}$ Nesse sentido, ALVIM, Pedro. O contrato de seguro, p. 441.

${ }^{222}$ SANTOS, Ricardo Bechara. Direito do seguro no novo Código Civil e legislação própria, p. 16.

${ }^{223}$ COMPARATO, Fabio Konder, op. cit., p. 136.

${ }^{224}$ A garantia - e não a indenização - é a principal prestação da seguradora (FRANCO, Vera Helena de Mello, op. cit., p. 302).

${ }^{225}$ Ibidem, p. 270.
} 
A divergência doutrinária sobre a prestação da seguradora decorre da ausência de consenso sobre a própria natureza do contrato de seguro: aleatória ou comutativa. $\mathrm{Na}$ qualidade de um contrato bilateral e oneroso, discute-se se a prestação devida pelo segurador é certa e definitiva ou, ao contrário, incerta, pois que dependente de um acontecimento aleatório.

A presença do risco leva muitos doutrinadores a enxergarem o contrato como tipicamente aleatório, identificando a prestação da seguradora na indenização, devida apenas na verificação do sinistro e sempre desproporcional ao prêmio pago pelo segurado $^{226}$.

Ainda sob a égide do Código Civil de 1916, Pontes de Miranda já lecionava que o prêmio

“[...] não corresponde à possível prestação da quantia do seguro, pelo segurador; porque a contraprestação do segurador é a vinculação, a assunção do risco. Portanto, corresponde ao valor econômico, técnico da dívida assumida, e não ao que o segurador terá de prestar, eventualmente" ${ }^{, 227}$.

Conforme explica Pasqualotto ${ }^{228}$, se a álea for considerada elemento externo ao contrato, a garantia caracteriza-se como prestação e o contrato como comutativo; em oposição, considerando-se a álea elemento interno, a garantia é a própria finalidade do contrato, não integrando a sua estrutura.

Nesse diapasão, como explica o autor em comento, a prestação do segurador continua sendo a indenização, devida apenas em caso de ocorrência do evento aleatório previsto no contrato. A garantia é aquilo que leva o segurado a contratar o seguro, portanto,

\footnotetext{
${ }^{226}$ Nesse sentido: ALVIM, Pedro. O contrato de seguro, p. 123; GOMES, Orlando. Contratos, p. 493; MARTINS, Fran. Contratos e obrigações comerciais. 14. ed. Rio de Janeiro: Forense, 1999. p. 359-360; PONTES DE MIRANDA, Francisco Cavalcante. Tratado de Direito Privado, t. XLV, p. 411.

${ }^{227}$ PONTES DE MIRANDA, Francisco Cavalcante, op. cit., p. 312.

${ }^{228}$ PASQUALOTTO, Adalberto. Os papéis da álea e da garantia no contrato de seguro: uma visão das leis portuguesa e brasileira. Revista dos Tribunais, n. 885, p. 21-22. O autor faz um interessante paralelo entre a concepção de garantia na lei brasileira e no Decreto-lei português n. 72/2008, em vigor desde $1^{\circ}$ de janeiro de 2009, cujo art. $1^{\mathrm{O}}$ assim define o contrato de seguro: "Por efeito do contrato de seguro, o segurador cobre um risco determinado do tomador de seguro ou de outrem, obrigando-se a realizar a prestação convencionada em caso de ocorrência do evento aleatório previsto no contrato, e o tomador do seguro obriga-se a pagar o prêmio correspondente" (ibidem).
} 
a própria causa do contrato, já que "realiza a função econômico-social de proteção dos interesses legítimos do segurado"229.

Pontes de Miranda, mesmo classificando o seguro como aleatório, propugna que a prestação do segurador consiste na cobertura do risco:

"Não se pode dizer que o segurador, se ocorre o sinistro, ou se cedo ocorre, presta a soma do seguro e, se não ocorre, enriquece-se com o prêmio, ao passo que o segurado, mesmo se há o sinistro, não ganha, porque só recebe a indenização que perdeu [...]. O risco foi coberto até que se desse o sinistro e o segurado obteve a cobertura; mesmo se o sinistro não sobreveio, cobriu-se-lhe o risco. Há sempre a prestação e a contra-prestação, porque a entrega da soma é em virtude do que aconteceu, devido à álea" ${ }^{230}$.

Os defensores da natureza comutativa apregoam que a aleatoriedade existe apenas no contrato isoladamente considerado, descontextualizado das bases técnicas da operação securitária. De fato, o seguro é necessariamente uma operação em massa, mediante a qual as consequências econômicas dos sinistros são repartidas entre uma pluralidade de pessoas expostas a um risco determinado, o que se denomina mutualidade. É o risco coletivo que interessa ao contrato de seguro, não o risco individual ${ }^{231}$. Essa massa de riscos homogêneos permite ao segurador, por meio das ciências atuariais, prever a possibilidade de incidência do risco em determinado espaço de tempo e, assim, estabelecer o montante necessário a ser rateado entre o segurados (prêmio), o que descaracteriza a "álea"232.

Por isso, ao qualificar o contrato de seguro como comutativo, a doutrina preconiza que a prestação do segurador não se limita ao pagamento de uma indenização eventual,

\footnotetext{
${ }^{229}$ PASQUALOTTO, Adalberto. Os papéis da álea e da garantia no contrato de seguro: uma visão das leis portuguesa e brasileira. Revista dos Tribunais, n. 885, p. 22.

${ }^{230}$ PONTES DE MIRANDA, Francisco Cavalcante. Tratado de Direito Privado, t. XLV, p. 285.

${ }^{231}$ É nesse sentido a conclusão de Stiglitz, que recorre a Fanelli: "La causa-fin económica-técnica del seguro alcanza su sentido en la dispersión del riesgo individual en una pluralidad o suma de economías individuales que conforman la noción de comunión de riesgos o mutualidad" (FANELLI, G. Diritto e técnica delle assicurazioni. In: STIGLITZ, Rubén S. Derecho de seguros, v. I, p. 22).

${ }^{232}$ Nesse sentido: FRANCO, Vera Helena de Mello. Lições de direito securitário: seguros terrestres privados, p. 270-272.
} 
mas consiste na prestação de uma garantia por toda a vigência do contrato $^{233}$. Piza, invocando Ippolito, assevera:

“[...] a obrigação do segurador é complexa, mas substancialmente única, e concretiza-se na prestação de segurança que - sendo vertida à preservação da esfera jurídico-patrimonial do segurado em relação ao evento descrito como risco - é necessariamente compreensiva da prestação indenizatória, a qual perde, assim, o seu caráter aleatório, havendo interdependência econômico-jurídica entre as respectivas atribuições patrimoniais, e resolve-se, portanto, numa prestação substancialmente equivalente" 234 .

O prêmio está também diretamente ligado a essa característica, tendo em vista que integra o lastro financeiro para pagamento das indenizações, essas sim eventuais, porque dependentes da concretização do risco ${ }^{235}$.

\subsubsection{Interesse e risco}

O conceito de interesse segurável, conforme anotado, está estreitamente ligado ao conceito de risco. Não obstante as inúmeras definições doutrinárias para interesse, é majoritariamente aceito que a definição de interesse segurável traz ínsita a ideia de conservação de determinado bem, contra um risco que o ameaça. Ou seja, o interesse, na qualidade de uma relação entre uma pessoa e uma coisa, não se confunde com o risco, mas, para ser segurável, há de ser ameaçado por ele.

\footnotetext{
${ }^{233}$ Nesse sentido: TZIRULNIK, Ernesto; CAVALCANTI, Flávio de Queiroz B.; PIMENTEL, Ayrton. $O$ contrato de seguro de acordo com o novo Código Civil brasileiro, p. 30-31.

${ }^{234}$ IPPOLITO, R. L'evoluzione normativa del rischio nella teoria dell'assicurazione. In: PIZA, Paulo Luiz de Toledo. Contrato de resseguro: tipologia, formação e direito internacional, p. 164.

${ }^{235}$ Nesse sentido: PASQUALOTTO, Adalberto. Os papéis da álea e da garantia no contrato de seguro: uma visão das leis portuguesa e brasileira. Revista dos Tribunais, n. 885, p. 16.
} 
Buttaro $^{236}$ consigna que a existência do risco não integra o conceito de interesse, mas constitui um requisito para que o interesse seja segurável.

Na mesma linha, Moitinho de Almeida sustenta que a noção de interesse se complementa com a noção de risco, na medida em que "um interesse não é segurável se não for sujeito a risco, assim como um risco não pode ser segurado se não existe um interesse" 237 . Risco, portanto, constitui não um elemento do interesse, mas seu próprio limite.

O risco não é um bem ou um evento danoso e, sim, a possibilidade de ocorrência de um evento pré-determinado no contrato, lesivo ao interesse garantido ${ }^{238}$. O risco pressupõe a imprevisibilidade, ou seja, que o evento seja possível, mas incerto ou de data incerta. Conforme Piza, interesse e risco constituem "o núcleo duro em torno do qual e em função do qual se definem e caracterizam as prestações correspondentes às obrigações constituídas contratualmente" 239 . Essa ideia é complementada por Comparato, segundo o qual o objeto de um negócio de seguro consiste sempre em um "interesse submetido a um risco": o interesse segurável é o próprio "objeto material do negócio” e o risco segurável é o "objeto formal ou modo de ser do interesse" ${ }^{, 40}$. Por isso, a estreita relação entre os dois elementos.

\subsubsection{A controvérsia sobre a empresarialidade como elemento do contrato de seguro}

A doutrina diverge no tocante ao entendimento de se a organização empresarial da seguradora que se encontra destacada no caput do art. 757 é um elemento do contrato de seguro ou apenas um requisito subjetivo do contrato $^{241}$.

\footnotetext{
${ }^{236}$ BUTTARO, Luca. L'interesse nell'assicurazione, p. 15.

${ }^{237}$ ALMEIDA, J. C. Moitinho de. O contrato de seguro no Direito Português e Comparado, p. 148-148.

${ }^{238}$ Cf. TZIRULNIK, Ernesto; CAVALCANTI, Flávio de Queiroz B.; PIMENTEL, Ayrton. O contrato de seguro de acordo com o novo Código Civil brasileiro, p. 36.

${ }^{239}$ PIZA, Paulo Luiz de Toledo. Contrato de resseguro: tipologia, formação e direito internacional, p. 176.

${ }^{240}$ COMPARATO, Flavio Konder. $O$ seguro de crédito, p. 23.

${ }^{241}$ Venosa explica que, "Pelo conceito léxico, elemento é tudo que se insere na composição de alguma coisa, cada parte de um todo. Pressuposto é a circunstância ou fato considerado como antecedente necessário de outro. E requisito é a condição necessária para a obtenção de certo objetivo, ou para preenchimento de certo fim.” (VENOSA, Silvio de Salvo. Direito Civil: contratos em espécie. 3. ed. São Paulo: Atlas, 2003).
} 
$\mathrm{O} \S 1^{\underline{0}}$ do art. 757 não estava previsto no projeto de Comparato, que não elenca a empresarialidade entre os quatro elementos do contrato de seguro ${ }^{242}$ mencionados neste estudo: prêmio, garantia, interesse e risco. A organização empresarial da seguradora já constava, porém, do Decreto-lei n. 73/66, no art. 24: "Poderão operar em seguros privados apenas Sociedades Anônimas ou Cooperativas, devidamente autorizadas".

Alvim, apesar de reconhecer a importância da organização empresarial, não chega a elencá-la como elemento essencial do contrato $^{243}$. Também para Pontes de Miranda a previsão legal estabelecia apenas um requisito para a manifestação de vontade válida da seguradora $^{244}$. Donati ${ }^{245}$, na mesma linha, nega o elemento empresarial, entendendo que o modo como a atividade é exercida representa um "pressuposto técnico".

A exigência da empresarialidade do contrato de seguro, conforme observado neste estudo, coube a Vivante, que desenvolveu a teoria da empresa calcado justamente no entendimento de que a organização empresarial da seguradora é um elemento essencial do contrato $^{246}$. Sustenta que, por meio do contrato de seguro, o segurador se obriga a inserir, segundo a técnica securitária, o risco individual numa massa de riscos homogêneos (mutualismo) de maneira que a cobertura do risco encontra sua compensação no pagamento do prêmio pelo segurado, sendo inegável que essa organização empresarial constitui um elemento que integra a estrutura do contrato ${ }^{247}$.

Entre nós, o posicionamento apontado é defendido por Tzirulnik, Cavalcanti e Pimentel. Esses doutrinadores entendem que a inclusão da previsão no parágrafo único do artigo inaugural do capítulo relativo ao contrato de seguro no Código Civil explicitou que "não se trata de requisito atinente apenas à parte, mas com irradiação mais ampla, incidente

\footnotetext{
${ }^{242}$ COMPARATO, Fabio Konder. Substitutivo ao capítulo referente ao contrato de seguro no anteprojeto do Código Civil. Revista de Direito Mercantil, n. 5, p. 147.

243 ALVIM, Pedro. O contrato de seguro, p. 180.

244 "No tocante aos pressupostos que as empresas de seguros têm de satisfazer para que possam operar, não se deve falar de capacidade, nem sequer de capacidade especial. Trata-se de requisitos de composição e de capital e de requisitos de validade das manifestações de vontade que podem vincular pelo contrato de seguro." (PONTES DE MIRANDA, Francisco Cavalcante. Tratado de Direito Privado: parte especial, t. XLVI, p. 408).

${ }^{245}$ DONATI, Antigono. Trattato del Diritto delle Assicurazioni Private, t. II, p. 42; p. 15-17.

${ }^{246}$ Cf. ASCARELLI, Tullio. O conceito unitário do contrato de seguro. In: anônimas e Direito Comparado, p. 209.

${ }^{247} \mathrm{O}$ autor português Moitinho de Almeida defende, igualmente, que a organização empresarial do segurador, sujeita às regras técnicas de funcionamento e à fiscalização do Estado, é elemento essencial do contrato, assim como o risco e prêmio (ALMEIDA, J. C. Moitinho de. O contrato de seguro no Direito Português e Comparado, p. 21).
} 


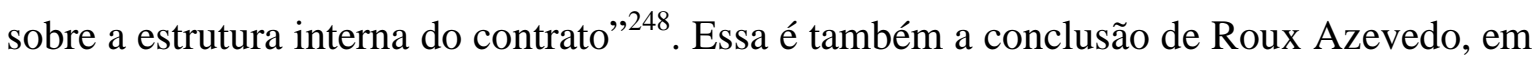
recente trabalho sobre a comutatividade do contrato de seguro ${ }^{249}$.

\subsection{O interesse como objeto do contrato de seguro}

O estudo estrutural do contrato de seguro ora menciona como seu objeto o interesse, ora o risco. As primeiras teorias aduziam que o bem como objeto do seguro, mas hoje já se encontram ultrapassadas ${ }^{250}$.

Conforme discutido anteriormente, na doutrina brasileira, é o interesse segurável o objeto material do contrato de seguro, a exemplo da lição de Comparato ${ }^{251}$, seguido por Mello Franco ${ }^{252}$, Piza $^{253}$, Tzirulnik ${ }^{254}$ e Bechara ${ }^{255}$.

\footnotetext{
${ }^{248}$ TZIRULNIK, Ernesto; CAVALCANTI, Flávio de Queiroz B.; PIMENTEL, Ayrton. O contrato de seguro de acordo com o novo código civil brasileiro, p. 39.

${ }^{249}$ ROUX AZEVEDO, Luis Augusto. A comutatividade do contrato de seguro. 2010. Dissertação (Mestrado) - Faculdade de Direito da Universidade de São Paulo, 2010. p. 69.

${ }^{250}$ Conforme explica Ferrarini, era essa a opinião de autores como Kisch, para quem somente com esforço se pode conceber uma relação como objeto da proteção securitária, pois o objeto da garantia contratual é sempre o bem e não a relação. Já doutrinadores como Ehrenzweig entendem que o objeto do seguro tanto pode ser o interesse como o bem ou o dano. Trata-se de mera questão terminológica, pois é o dano patrimonial previsto no $§ 1$ da Lei alemã o conceito central de toda a doutrina securitária, e não o interesse. Ferrarini sustenta, no entanto, que o dano não pode ser considerado o conceito central da doutrina securitária, já que aquele é eventual, pode não acontecer e na maioria das vezes não acontece. $\mathrm{O}$ interesse, ao contrário, existe não apenas na conclusão do contrato, mas se prolonga por toda a sua vida (FERRARINI, Sergio. L'interesse nell'assicurazione, p. 19-20).

${ }^{251}$ COMPARATO, Flavio Konder. $O$ seguro de crédito, p. 23.

252 "A assim ser, o interesse é o objeto (material) do contrato. Vale dizer: a relação valorizada de uma pessoa perante um bem ou outra pessoa, que se coloca em risco. E é justamente sobre o valor dessa relação que incide o contrato de seguros, valor este a ser compensado na hipótese de sinistro" (FRANCO, Vera Helena de Mello.Contratos no Direito Privado: direito civil e empresarial, p. 292).

253 " "[...] o risco é que estaria dando forma, moldando o interesse, caracterizando-o. Se o que muda é a forma (o risco) e não a substância (o interesse), então o elemento estável (o ser) é sempre a substância (o interesse). É pois o interesse a matéria de que o contrato de seguro é feito, mas desde, evidentemente, que haja risco, conformando-o. Em face disso é que se pode apreciar o interesse, tal qual caracterizado pelo risco, em termos de licitude. Nesse aspecto, enfim, é que se refere acima o interesse (objeto material) e o risco (objeto formal), em conjunto, como o núcleo duro do objeto securitário" (PIZA, Paulo Luiz de Toledo. Contrato de resseguro: tipologia, formação e direito internacional, p. 178-179).

254 "A garantia tem como objeto o legítimo interesse do segurado" (op. cit., p. 32).

255 "Infere-se que o objeto do contrato de seguro não é o bem material (automóvel, casa, navio, etc.) ou imaterial (a vida, integridade física, etc.), mas o interesse legítimo sobre esses bens. E o que é o interesse legítimo senão a relação lícita de valor econômico sobre um bem? Se essa relação encontra-se ameaçada por um risco, estaremos diante de um interesse legítimo segurável que vem a ser objeto de qualquer contrato de seguro, seja ele de dano ou de pessoa, repita-se a exaustão" (SANTOS, Ricardo Bechara, Direito do seguro no novo Código Civil e legislação própria, p. 18).
} 
O entendimento apontado é, ainda, compartilhado por vários doutrinadores estrangeiros, como Halperin ${ }^{256}$ e Buttaro ${ }^{257}$.

De fato, é o interesse segurável como objeto do contrato que explica a possibilidade de existirem diversos seguros sobre o mesmo bem, com titulares diferentes ${ }^{258}$. Trata-se, pois, o interesse do próprio elemento inderrogável objetivo, que define o objeto típico e fixa o regime jurídico a que o negócio obedece. Conforme explica Halperin ${ }^{259}$, é o interesse que condiciona o conteúdo do contrato de seguro e que determina seu valor. Por isso, diferentes relações com um mesmo bem podem produzir seguros diversos, de valores e titulares diversos, de acordo com o interesse sobre o qual incide a garantia:

\begin{abstract}
"La materia del seguro está dada por el interés: su clase y extensión, y no por la cosa sobre la que versa el interés. La sustitución de la cosa asegurada por el interés asegurado, se funda ante todo en la noción de que no es la cosa como tal, sino que la relación con ella representa un valor, que el asegurador debe indemnizar conforme al contrato si disminuye o se destruye a consecuencia del acaecimiento del hecho previsto en el contrato. El asegurador, como cualquier otro, no puede impedir el daño o destrucción de la cosa. Además, la cosa es una unidad objetiva; en cambio las relaciones que la afectan son múltiples y en cada caso tienen características individuales. Si la cosa fuera el objeto del seguro, todos los seguros de la misma cosa serían entonces económicamente iguales, sin variación según el interés: la misma cosa condicionaría el mismo contenido de todos los seguros. Y en
\end{abstract}

\footnotetext{
256 "El concepto de interés asegurable adquiere en el contrato de seguro una importancia extraordinaria, porque constituye el objeto del contrato; su existencia es esencial para legitimar el contrato e impedir que degenere en una apuesta, y porque en el seguro de daños, es la medida de la indemnización. Debe determinarse de manera precisa para evitar que el contrato pueda derivar en apuesta o juego, o sea incentivo para destruir la cosa" (HALPERIN, Isaac. El contrato de seguro, p. 427).

${ }^{257}$ BUTTARO, Luca. L'interesse nell'assicurazione, p. 63.

${ }^{258}$ Nesse sentido, explica Comparato: "Na verdade, mesmo no chamado seguro de coisas determinadas, como o seguro de incêndio ou o seguro contra o furto, o que o segurado garante pelo contrato não é propriamente uma coisa, mas o interesse que possui em relação a esta coisa. [...] A distinção entre interesse segurável e a coisa ou o objeto a que este interesse se refere explica o fato de que possa existir às vezes uma multiplicidade de seguros do mesmo tipo referentes à mesma coisa, com titulares diferentes. É o caso, por exemplo, do seguro de incêndio contratado pelo proprietário (ou credor hipotecário), pelo usufrutuário e pelo locatário com referência ao mesmo imóvel, cada qual protegendo um interesse econômico diverso" (COMPARATO, Flavio Konder. O seguro de crédito, p. 24-26).

${ }^{259}$ HALPERIN, Isaac, op. cit.
} 
cambio las distintas relaciones individuales sobre la cosa asegurada, producen seguros económicamente distintos: el distinto objeto del seguro condiciona su distinto contenido" 260 .

Na mesma esteira, Ferrarini ${ }^{261}$ destaca que, nos seguros de dano, é o interesse que permite distinguir os diversos seguros sobre o mesmo bem, assim como definir o valor do seguro, as consequências do duplo seguro e a possibilidade de separar, na venda do bem segurado, o momento da transferência do bem e o momento da transferência do interesse segurável $^{262}$.

Piza, alinhando-se com Comparato, sustenta que

“[...] o risco é que estaria dando forma, moldando o interesse, caracterizando-o. Se o que muda é a forma (o risco) e não a substância (o interesse), então o elemento estável (o ser) é sempre a substância (o interesse) É, pois, o interesse a matéria de que o contrato de seguro é feito, mas desde, evidentemente, que haja risco, conformando-o. Em face disso é que se pode apreciar o interesse, tal qual caracterizado pelo risco, em termos de licitude. Nesse aspecto, enfim, é que se refere acima o interesse (objeto material) e o risco (objeto formal), em conjunto, como o núcleo duro do objeto securitário"263.

Para o interesse é objeto do contrato, uma vez que: "1) Sua existência legitima o contrato; 2) Impede que o seguro se degenere em aposta; 3) Impede o incentivo de destruir o bem sobre o qual recai o interesse" ${ }^{\text {264 }}$. Há, aqui, aparente confusão entre a função do interesse segurável no contrato de seguro e as razões pelas quais deve ser considerado o seu objeto.

\footnotetext{
${ }^{260}$ HALPERIN, Isaac. El contrato de seguro, p. 428-429.

${ }^{261}$ FERRARINI, Sergio. L'interesse nell'assicurazione, p. 19).

${ }^{262}$ COMPARATO, Fabio Konder. O seguro de crédito, p. 24.

${ }^{263}$ PIZA, Paulo Luiz de Toledo. Contrato de resseguro: tipologia, formação e direito internacional, p. $178-179$.

${ }^{264}$ MAGALLANES, Pablo Medina. O interesse segurável. In: III FÓRUM DE DIREITO DO SEGURO “JOSÉ SOLLERO FILHO”, p. 398.
} 
A posição de que o risco é o objeto do contrato é defendida, na Argentina, por Stiglitz ${ }^{265}$; na Itália, por Ascarelli ${ }^{266}$ e Fanelli $^{267}$; e, na França, por Provost ${ }^{268}$.

Na visão de Stiglitz ${ }^{269}$, a cobertura securitária incide sobre o risco, conforme se depreende da própria redação do art. $2^{2}$ da Lei de Seguros n. 17.418 de 1967, que estabelece: "O contrato de seguro pode ter por objeto toda classe de riscos se existe

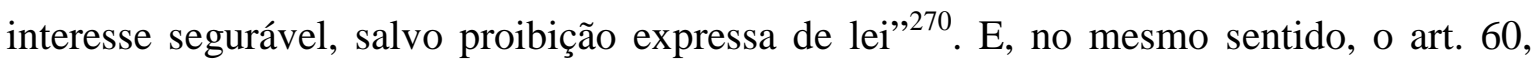
aplicável somente para os seguros de danos: "Pode ser objeto destes seguros qualquer risco se existe interesse econômico lícito de que o sinistro não ocorra"271. Para o autor argentino, o interesse lícito de que um sinistro não ocorra é a causa do contrato, pois consiste no motivo determinante da contratação ${ }^{272}$.

O entendimento de Provost, de que é o risco o objeto do contrato de seguro, denota contrariar o disposto no art. 121-6 do Código de Seguros, conforme reproduzido a seguir: “Quaisquer interesses diretos ou indiretos na não realização de um risco podem ser objeto de um seguro" 273 .

Para Provost ${ }^{274}$, na doutrina majoritária da França, o interesse segurável tem a função de qualificar o contrato de seguro e, em princípio, não figura entre os elementos

${ }^{265}$ STIGLITZ, Rubén S. Derecho de seguros, v. I, p. 186-187.

266 Ascarelli, seguindo a doutrina de Vivante, defende que o objeto do contrato de seguro é o risco (ASCARELLI, Tullio. O conceito unitário do contrato de seguro. In: Problemas das sociedades anônimas e Direito Comparado, p. 212.

${ }^{267}$ FANELLI, G. Considerazione sull concetto giuridico di rischio nell'assicurazione. In: STIGLITZ, Rubén

S. Derecho de seguros, v. I, p. 187.

${ }^{268}$ PROVOST, Magalie. La notion d'intérêt d'assurance, p. 288.

${ }^{269}$ STIGLITZ, Rubén S. op. cit., p. 186-187.

${ }^{270}$ Tradução livre do original: "El contrato de seguro puede tener por objeto toda clase de riesgos si existe interés asegurable, salvo prohibición expresa de la ley".

${ }^{271}$ Tradução livre do original: "Puede ser objeto de estos seguros cualquier riesgo si existe interés económico lícito en que un siniestro no occura".

${ }^{272}$ Sobre a distinção entre objeto e causa do contrato, explica o autor: "El objeto (la materia de que se trata) del contrato lo constituye el intercambio de una prima o cotización a cargo del asegurado, por el resarcimiento de un daño o el cumplimiento de la prestación a cargo del asegurador si se verifica un evento suscetible de provocar un daño, o se cumple el presupuesto al que se halla subordinado el cumplimiento de la prestación. En cambio, la causa-fin examina el motivo determinante de la contratación, la razón de ser del contrato, los factores o móviles que han determinado a lastar a contratar, el fin perseguido, los motivos individuales, siempre y cuando hayan sido incorporados al 'campo' contractual y sean conocidos (conocibles) por las partes” (STIGLITZ, Rubén S., op. cit., p. 272, nota de rodapé n. 9).

${ }^{273}$ Tradução livre do art. L. 121-6: "Toute personne ayant intérêt à la conservation d'une chose peut la faire assurer. Tout intérêt direct ou indirect à la non-réalisation d'un risque peut faire l'objet d'une assurance". A mesma disposição se verifica no título destinado ao contrato de seguro marítimo e de seguro fluvial e lacustre, no qual o interesse segurável é tratado no art. L 171-3: "Tout intérêt legitime, y compris le profit espéré, peut faire l'object d'une assurance. Nul ne peut réclamer le bénéfice d'une assurances s'il n'a pas éprouvé un préjudice".

${ }^{274}$ A autora recorre a Lambert-Faivre para definir o contrato de seguro: "une convention par laquelle, en contrepartie d'une prime, l'assureur s'engage à garantir le souscripteur en cas de réalization d'un risque aléatoire prévu au contrat. Cette définition, ajoutent-ils, 'souligne les trois éléments constitutifs de la nature 
essenciais do contrato - o risco, o prêmio e a garantia ${ }^{275}$-, já que está previsto apenas no capítulo referente ao seguro de dano. De acordo com a autora, se o interesse fosse um elemento essencial do contrato de seguro, não poderia deixar de integrar também o seguro de pessoas $^{276}$.

Buttaro afirma que, apesar de sua relevância, o risco não pode ser considerado objeto do contrato. Segundo o autor, esse pensamento baseia-se em uma premissa equivocada, defendida pela Teoria da Transferência do Risco, segundo a qual, da mesma forma que na venda o bem passa do vendedor ao comprador, no seguro, o risco que recai sobre o segurado é transferido para a seguradora e essa sofre por isso todas as consequências da transferência, incluindo a de pagar a indenização.

Conforme ressaltado na crítica à referida doutrina, não se opera uma transferência de risco pelo contrato de seguro. O risco suportado pela seguradora é bem diferente daquele temido pelo segurado e, mesmo diante da existência do contrato de seguro, o segurado sofrerá igualmente as consequências do sinistro. A seguradora intervirá somente em um segundo momento para pagar a indenização ou o capital segurado ${ }^{277}$.

Risco, continua o autor, indica simplesmente uma probabilidade, mais especificamente a probabilidade do sinistro que ameaça o interesse do segurado. A probabilidade não é um bem, e não é nem mesmo a negação de um bem (dano), que pode eventualmente justificar um interesse de retorno ao status quo ante, mas indica apenas algo que pode acontecer, que, porém, assim que acontece deixa de ser risco para tornar-se sinistro $^{278}$. Ademais, o risco, ainda que determinado ou determinável, não é suscetível de valoração econômica, característica que impede que seja objeto do contrato ${ }^{279}$.

\footnotetext{
spécifique du contrat d'assurance: un risque, une prime, une prestation de garantie en cas de sinistre", (LAMBERT-FAIVRE, Y.; LEVENEUR, L. Droit des assurances. In: PROVOST, Magalie. La notion d'intérêt d'assurance, p. 145).

${ }^{275}$ Note-se que Provost, apesar de invocar a noção de garantia, classifica o contrato de seguro como aleatório: "Bien que le contrat d'assurance soit un contrat aléatoire qui comporte une chance de gain et un risque de perte, le mot 'chance' ne désigne jamais le risqui assuré, car la chance désigne une éventualité heureuse (on parle de chance de succès), tandis que le resque s'entend d'un danger ou d'un inconvénient éventuel (on parle alors de 'risque' d'echec)" (PROVOST, Magalie, op. cit., p. 155).

${ }^{276}$ Ibidem, p. 145.

${ }^{277}$ BUTTARO, Luca. L'interesse nell'assicurazione, p. 56-57.

${ }^{278}$ Ibidem, p. 60.

${ }^{279}$ Ibidem, p. 60-61.
} 


\subsection{O interesse como causa do contrato de seguro}

O interesse como causa do contrato tem como principal defensora a doutrina argentina que, consoante já referido, aponta o risco como seu objeto.

Junqueira elucida que:

“[...] causa é um fato externo ao negócio, mas que o justifica do ponto de vista social e jurídico, enquanto que o elemento categorial objetivo é justamente a referência, que se faz a esse fato, no próprio conteúdo do negócio. Por outras palavras, o elemento inderrogável objetivo faz parte, isto é, é integrante da estrutura do negócio, e a causa não. O elemento categorial objetivo consiste numa referência à causa, a qual está, porém, fora do negócio (ela está logicamente, ou antes ou depois, mas não no negócio, ela é extrínseca à sua constituição)" 280 .

Para Stiglitz, o objeto responde à pergunta sobre o que é devido pelas partes, enquanto a causa responde por que se deve, ou seja, a causa refere-se aos motivos considerados pelas partes para a celebração do contrato ${ }^{281}$. Preconiza, pois, o autor que o interesse lícito de que um sinistro não ocorra é justamente a causa do contrato, por ser o motivo determinante da contratação.

Segundo Mello Franco ${ }^{282}$ e Buttaro ${ }^{283}$, a posição apontada revela uma confusão entre causa em sentido subjetivo, entendida como o motivo que impulsiona a contratação, e causa em sentido objetivo, ou seja, a função econômico-social que indica para que o negócio tende.

Conforme Pizza ${ }^{284}$, a função do seguro é justamente a coletivização do risco, por meio da formação de um fundo comum para fazer frente aos sinistros. Para Mello

\footnotetext{
${ }^{280}$ AZEVEDO, Antonio Junqueira de. Negócio jurídico: existência, validade e eficácia, p. 147-148.

${ }^{281}$ STIGLITZ, Rubén S. Objeto, causa y frustración del contrato. Buenos Aires: Depalma, 1992. p. 19-20.

${ }^{282}$ FRANCO, Vera Helena de Mello. Contratos no Direito Privado: direito civil e empresarial, p. 291.

${ }^{283}$ BUTTARO. L'interesse nell'assicurazione, p. 163.

${ }^{284}$ PIZA, Paulo Luiz de Toledo. Contrato de resseguro: tipologia, formação e direito internacional, p. 159.
} 
Franco $^{285}$, a função constante e típica de toda operação securitária e, portanto, sua causa em sentido objetivo é a prevenção de riscos.

Já a causa em sentido subjetivo deve enfatizar o fim prático da contratação, ou seja, a utilidade que emerge como típica do contrato, não se confundindo com os motivos pessoais de cada indivíduo ${ }^{286}$.

De acordo com Buttaro ${ }^{287}$, para determinar a causa objetiva, é necessário analisar o vínculo entre a prestação do segurado e a prestação do segurador e, assim, o próprio fim do contrato. Nesse raciocínio, o segurador, em troca do pagamento do prêmio, garante o interesse do segurado contra determinados riscos, de modo que a causa do contrato é a própria prestação do segurador de garantia ${ }^{288}$. No contexto de tais acepções doutrinárias, portanto, a causa, seja tanto no sentido objetivo como no subjetivo, faz referência ao interesse, mas com ele não se identifica.

\subsection{O interesse como requisito de validade}

Conforme assinalado, no direito francês ${ }^{289}$, o interesse segurável tem a função de qualificar o contrato de seguro e, em princípio, não figura entre os elementos essenciais do contrato, quais sejam, o risco, o prêmio e a garantia ${ }^{290}$.

De acordo com a doutrina francesa, no seguro de dano, verifica-se a clara relação entre risco e interesse. Consoante dicção do art. L-121-6 do Código de Seguros francês, o risco, no seguro de dano, pode ser definido como "a possibilidade de um evento temido por aquele que tem interesse em se prevenir através de um seguro" ${ }^{\text {291 }}$. É, assim, o temor do

\footnotetext{
${ }^{285}$ FRANCO, Vera Helena de Mello. Contratos no Direito Privado: direito civil e empresarial, p. 292.

${ }^{286}$ PIZA, Paulo Luiz de Toledo. Contrato de resseguro: tipologia, formação e direito internacional, p. 159.

${ }^{287}$ Ibidem, p. 183.

${ }^{288}$ No mesmo sentido: PIZA, Paulo Luiz de Toledo, op. cit., p. 159-172; e FRANCO, Vera Helena de Mello, op. cit., p. 292.

${ }^{289}$ LAMBERT-FAIVRE, Y.; LEVENEUR, L. Droit des assurances. In: PROVOST, Magalie. La notion d'intérêt d'assurance, p. 145.)

${ }^{290}$ PROVOST, Magalie. La notion d'intérêt d'assurance, p. 155.

291 Tradução livre de: "le risque est l'éventualité d'un événement redoute contre lequel le souscripteur a intérêt à se prémunir en contractant une assurance" (PROVOST, Magalie, op. cit., p. 156).
} 
risco, entendido como o evento passível de causar consequências economicamente danosas ao segurado, que faz surgir o interesse em concluir um seguro de dano ${ }^{292}$.

Já no seguro de pessoas, o risco é tão somente o evento aleatório que desencadeia a garantia securitária. A ideia de perigo, de temor de sua ocorrência, de dano, não integra necessariamente a noção do risco aqui considerado, de modo que também não é exigido o interesse na não realização do risco como requisito de validade do contrato ${ }^{293}$.

Provost, todavia, discorda desse posicionamento, por entender que o interesse é um componente do risco, tanto no seguro de dano como no seguro de pessoas e, nessa qualidade, constitui um elemento essencial de todos os contratos de seguro. Para a autora, não existe um risco sem um interesse segurável ${ }^{294}$.

Buttaro também diverge de parcela da doutrina que atribui ao interesse segurável o papel de "pressuposto de validade" ${ }^{295}$. Conforme explica, pressuposto é fator externo à relação negocial, cuja ausência acarreta a nulidade do negócio, mesmo que presentes todos os seus elementos essenciais. Exemplo emblemático são os requisitos de manifestação de vontade, como a capacidade de agir e a idoneidade do objeto. $\mathrm{O}$ pressuposto, portanto, atua estritamente no plano da validade, enquanto o elemento atua no plano da própria existência do contrato ${ }^{296}$.

Nessa trilha, conclui o autor que não é esse o papel do interesse segurável. O interesse, de fato, não se refere ao elemento subjetivo ou objetivo, mas indica relação: a relação que liga o sujeito ao bem. O interesse não representa, portanto, o juízo do sujeito sobre a utilidade de um bem, ou sua capacidade de dispor do mesmo bem, e tampouco constitui um requisito de idoneidade do bem, mas se identifica com a própria relação entre o sujeito e o objeto ${ }^{297}$.

Buttaro, que classifica o contrato de seguro como comutativo, ressalta que nesse tipo de negócio não há transferência de um bem e não se constitui um direito de gozo de alguma utilidade desse bem, mas há apenas a preocupação de proteger o bem, ou melhor,

\footnotetext{
${ }^{292}$ PROVOST, Magalie. La notion d'intérêt d'assurance, p. 158.

${ }^{293}$ Ibidem, p. 160-170.

${ }^{294}$ Ibidem, p. 267.

295 Diz o autor: "La doutrina è concorde nel riconescere la necessità dell'interesse, non entretanto nel determinare em quale manieira lo stesso acquisti rilevanza nel rapporto o più esatamente quale posizione occupi nella fattispecie contrattuale. Si tratta semplicemente di um presuposto o costituice uno degli elementi essenziali del contrato e quale? (BUTTARO, Luca. L'interesse nell'assicurazione, p. 25).

${ }^{296}$ Ibidem, p. 27-28

${ }^{297}$ Ibidem, p. 32.
} 
de proteger o interesse que o sujeito possui em relação ao bem, dos perigos que pesam sobre este ${ }^{298}$.

O conteúdo diverso do contrato de seguro, cujo elemento peculiar não se trata de um bem ou mesmo de qualquer coisa de concreto, mas da probabilidade que um fato indesejado ocorra, demonstra a relevância do interesse, pois é nele que o evento danoso produz efeito. $\mathrm{O}$ dano atinge a relação entre o sujeito e o bem, destruindo ou diminuindo a sua utilidade ${ }^{299}$.

A diferença do contrato de seguro para os demais contratos comutativos consiste, assim, no fato de que a relação entre o sujeito e o objeto não é necessária apenas para apontar se o segurado tem legitimidade para concluir o contrato, nem serve para determinar a idoneidade do objeto, uma vez que o objeto do contrato é o próprio interesse, não o bem. A lesão do interesse é sempre uma consequência da modificação da relação entre o bem e o indivíduo $^{300}$.

O indivíduo deseja que essa relação subsista e se preocupa em adotar as medidas necessárias para salvaguardar as consequências de um sinistro não realiza um ato de disposição de um bem, mas busca remover o perigo que ameaça o próprio patrimônio. Resulta, assim, evidente que o perigo não incide sobre o bem, mas unicamente sobre o interesse ${ }^{301}$.

\footnotetext{
${ }^{298}$ BUTTARO, Luca. L'interesse nell'assicurazione, p. 35.

${ }^{299}$ Ibidem, p. 36.

${ }^{300}$ Ibidem, p. 36-39.

${ }^{301}$ Ibidem, p. 39-40.
} 


\section{CAPÍTULO 4 \\ O INTERESSE SEGURÁVEL NO SEGURO DE COISA}

\subsection{Diferenciação entre o seguro de coisa e o seguro de responsabilidade civil}

Os seguros de dano, conforme demonstrado, visam ao recebimento de uma indenização em decorrência de um dano sofrido pelo segurado. Sua função é ressarcir os prejuízos, com a finalidade de recolocar o segurado na situação anterior à da ocorrência do sinistro $^{302}$.

Subdividem-se em duas modalidades: o seguro de danos diretos ou de coisa e o seguro de danos indiretos ou de responsabilidade civil $^{303}$. Ambos se sujeitam ao princípio indenitário, pelo qual o segurado deve ser indenizado na medida exata do prejuízo sofrido, a fim de que o seguro não se transforme em fonte de lucro.

Liard dá a dimensão do princípio, que, como ele lembra, é tão antigo quanto o seguro e presente em todas as legislações sobre a matéria:

"Um grande princípio domina toda a matéria: o seguro é um
contrato de indenização: ela não deve ensejar ao segurado, vítima
do sinistro, um enriquecimento; o segurado não pode obter lucro do
funcionamento do seguro; receberá uma indenização igual ao
prejuízo sofrido, mas, em hipótese alguma, superior. É um
princípio, essencial, tão antigo quanto o seguro mesmo, cuja
aplicação se encontra em todas as legislações e que, atualmente,
por sua importância, aparece como um traço fundamental do
seguro, por restringir esse contrato aos limites da função econômica
que lhe é própria, função de reparação e de indenização. Erigiram
essa idéia de reparação e de indenização à altura de um princípio de
ordem pública. [...] O seguro não pode ser uma causa de lucro para

\footnotetext{
${ }^{302}$ Conforme ALVIM, Pedro. O contrato de seguro, p. 79.

${ }^{303}$ Denominação adotada por FRANCO, Vera Helena de Mello. Contratos no Direito Privado:direito civil e empresarial, p. 308-309.
} 
o segurado; não lhe garante mais que a preparação de suas perdas reais. É uma garantia de conservação, não de aquisição"304.

A doutrina aponta diversos critérios para se distinguir o seguro de coisa do seguro de responsabilidade civil. Para Ferrarini ${ }^{305}$, ainda que vários critérios possam ser invocados, o principal deles se refere ao bem, objeto do interesse. O seguro de coisa, também chamado de seguros de danos diretos, tem por objetivo indenizar uma perda material ou patrimonial sofrida pelo segurado decorrente do dano que atinge diretamente um bem determinado ou determinável, ao qual se reporta o interesse. Em razão da natureza do bem, é possível estabelecer o valor do interesse segurável, ainda que por estimativa - no caso do benefício esperado ou lucro cessante.

Já no seguro de danos indiretos ou de responsabilidade civil, o bem objeto do interesse é o próprio patrimônio do segurado. O patrimônio não é um bem determinado ou determinável, mas um conjunto de relações ativas e passivas, uma universalidade de direitos $^{306}$. Por essa razão, não é possível fixar o dano máximo que pode sofrer um patrimônio. Ou seja, não há como determinar previamente qual seria o valor do interesse segurável, que deve equivaler justamente ao dano máximo que pode sofrer um bem, apenas e tão somente o valor do interesse segurado, entendido como o limite de garantia estabelecido com o segurador ${ }^{307}$.

O dano ao patrimônio é, ademais, indireto, na medida em que depende de ficar caracterizada a responsabilidade do segurado pelos danos causados a um terceiro, ao passo que o dano ao bem individualmente determinado atinge diretamente o patrimônio do segurado.

Morandi, com arrimo na doutrina de Donati, critica o critério de distinção apontado, aduzindo que o risco sempre ameaça o patrimônio, em seu sentido econômico, ainda que se refira a um bem determinado. Por isso, considera mais adequado diferenciar tais seguros

\footnotetext{
${ }^{304}$ LIARD, Michel. Assurance maritime et assurance terrestre, p. 117/120. In: ALVIM, Pedro. O seguro e o novo Código Civil, p. 95-96.

${ }^{305}$ FERRARINI, Sergio. L'interesse nell'assicurazione, p. 77-79.

${ }^{306}$ RODRIGUES, Silvio. Direito civil - parte geral, v. 1, p. 99.

${ }^{307} \mathrm{O}$ interesse segurável refere-se ao interesse anterior à contratação, passando a ser interesse segurado, uma vez estabelecido o vínculo jurídico (TZIRULNIK, Ernesto. Em torno do interesse segurável e da responsabilidade civil, In: ESCOLA PAULISTA DE MAGISTRATURA/EPM; INSTITUTO BRASILEIRO DE DIREITO DO SEGURO - IBDS. Seguros: uma questão atual. (Estudos de Direito do Seguro). São Paulo: Max Limonad, 2001).
} 
relativamente ao risco, que nos seguros de responsabilidade civil está representado sempre pelo surgimento de uma dívida para o segurado.

A doutrina majoritária adota posição intermediária, distinguindo as referidas subespécies de seguros tanto no que tange ao bem, objeto do interesse, como ao risco ${ }^{308}$. De fato, a distinção do interesse, relativamente ao seu objeto, no seguro de coisa e no seguro de responsabilidade civil, é fundamental para demonstrar o diferente tratamento legislativo no tocante ao valor segurável em cada caso e às consequências de eventual insuficiência ou excesso de garantia.

Ainda, conforme mencionado, diversas relações podem se estabelecer entre o sujeito e um bem determinado, possibilitando variados tipos de interesses, ao passo que no seguro de responsabilidade a única relação que se estabelece entre um sujeito e o seu património é de propriedade. Essa pluralidade de relações possíveis, presente no seguro de coisa, impacta tanto na legitimação para contratar como para receber a indenização securitária. No seguro de responsabilidade, como se verá, a discussão refere-se tão somente à titularidade do beneficiário da indenização. Daí a necessidade de um capítulo específico para cada subtipo do seguro de dano.

\subsection{Legitimação para contratar no seguro de coisa}

De acordo com o Código Civil de 2002, somente podem contratar os titulares de interesse legítimo, ou seja, aqueles que possuam uma relação juridicamente protegida com o bem, estando sujeitos ao dano consequente da sua perda ou destruição.

Conforme explica Halperin ${ }^{309}$, nos seguros de coisas, as classes de relações que se estabelecem entre um sujeito e um bem são múltiplas; por isso, é que um mesmo bem pode

\footnotetext{
${ }^{308}$ Nesse sentido, ver FRANCO, Vera Helena de Mello. Contratos no Direito Privado: direito civil e empresarial. Segundo a autora, nos seguros de danos diretos, o bem, objeto do interesse, é uma coisa individualmente determinada que integra ou poderá integrar o patimônio do segurado, ao passo que no seguro de responsabilidade civil, o bem não é uma coisa determinada no patrimônio, mas o próprio patrimônio. Destaca ainda que, no primeiro, o risco é um fato natural, enquanto no segundo é um fato jurídico, ou seja, a própria responsabilidade civil, "expresso na eventual ação de indenização proposta por terceiro" (ibidem, p. 314-315).

${ }^{309}$ HALPERIN, Isaac. El contrato de seguro, p. 432.
} 
ser objeto de diversos interesses e de diferentes seguros, de acordo com as várias relações a que ele está sujeito.

Não há consenso na doutrina sobre a classificação desses interesses que podem incidir sobre ele ${ }^{310}$. Será utilizado, aqui, o critério adotado por Ferrarini ${ }^{311}$, que classifica o interesse, no seguro de coisa, como interesse material ${ }^{312}$, interesse concorrente e interesse sobre lucro.

\subsubsection{O interesse material}

Exemplo típico de interesse material ${ }^{313}$ é o interesse do proprietário.

O proprietário de uma coisa, em regra, possui com ela uma relação econômica, cujo valor corresponde àquele da coisa indene. Se há a perda da coisa, ele sofrerá diretamente o prejuízo em seu patrimônio, independentemente de outros interesses que incidam sobre o mesmo bem.. Dessa relação econômica que se estabelece entre sujeito e coisa deriva um interesse material, compreendido como um interesse na própria matéria do bem, pois o valor do interesse é, em regra, o valor material da coisa exposta ao risco. Se houver mais de um proprietário sobre o mesmo bem, todos terão interesse, cujo valor corresponde àquele da cota de copropriedade de cada um.

Conforme exposto, esse interesse material é de índole puramanente econômica e incide tanto sobre um coisa quanto sobre um direito, "por isso se fala de propriedade de um bem ou de um direito, não em senso jurídico, mas em senso econômico"314.

Para Ferrarini, além do interesse do proprietário, podem coexistir outros interesses materiais equivalentes ao do proprietário sobre o mesmo bem que, no entanto, não

\footnotetext{
${ }^{310}$ A título ilustrativo, anota-se que Mello Franco cita a classificação de Garrigues, para quem os interesses podem ser coincidentes, concorrentes ou complementares ou independentes (FRANCO, Vera Helena de Mello. Contratos no Direito Privado: direito civil e empresarial, p. 292). Medina invoca Halperin e classifica os interesses em alternativo, sucessivo, complementar, neutro ou excludente (MAGALLANES, Pablo Medina. Interesse segurável. In: III FÓRUM DE DIREITO DO SEGURO, p. 378).

${ }^{311}$ FERRARINI, Sergio. L'interesse nell'assicurazione, p. 47-52.

${ }^{312}$ Ferrarini denomina interesse sulla sostanza (FERRARINI, Sergio. L'interesse nell'assicurazione, p. 53). Entende-se, todavia, que interesse material (relativo à matéria do bem) é mais adequado do que interesse "na substância", que seria a tradução literal da expressão utilizada pelo autor italiano.

${ }^{313}$ Ibidem, p.52.

${ }^{314}$ Ibidem, p. 53.
} 
diminuem ou limitam o primeiro ${ }^{315}$. Ou seja, o interesse material não é exclusivo do proprietário, mas também daqueles que por força de um direito sobre o bem de outrem tenham sobre esse um uso ou uma disponibilidade equivalente à do proprietário. ${ }^{316}$

O que define a existência de um direito material, portanto, é o fato de seu titular suportar diretamente os danos que atingem o bem ${ }^{317}$.

\subsubsection{Interesses concorrentes}

Além do proprietário (em sentido lato), outras pessoas podem ter interesse na conservação do bem por força de outros direitos que podem coexistir com aquele de propriedade. É o caso do credor hipotecário do usufrutuário e e do locatário. Tais interesses concorrem com o interesse material (do proprietário ou equivalente) no que atine ao bem a que se referem, e por isso são comumente denominados interesses concorrentes.

Os interesses dito concorrentes são completamente independentes e não diminuem nem anulam o interesse material. Ambos coexistem e são, portanto, igualmente seguráveis, de acordo com o risco a que estão expostos, e não significam o duplo seguro sobre o mesmo bem, justamente porque não há identidade de interesses, ainda que haja identidade de risco (incêndio, por exemplo) ${ }^{318}$.

Segundo Ferrarini ${ }^{319}$, os interesses concorrentes sobre determinado bem estão garantidos, indiretamente, pelo seguro do interesse material. Trata-se de uma garantia “em

\footnotetext{
${ }^{315}$ Anota Ferrarini que Ehrenberg entendia que a soma de todos os interesses constitui o interesse material, "mas a opinião não pode ser compartilhada, porque os interesses que podem incidir sobre um bem são de diferentes espécies e não são parte de um interesse único e geral” (FERRARINI, Sergio. L'interesse nell'assicurazione, p. 53). Halperin também não admite o interesse concorrente, pois somente há duas classes de prejuizos: aquele que afeta a matéria do bem ou aquele que afeta o lucro esperado (HALPERIN, Isaac. El contrato de seguro, p. 431).

${ }^{316} \mathrm{O}$ autor invoca o exemplo do enfiteuta (FERRARINI, Sergio, op. cit., p. 54).

${ }^{317}$ Ibidem, p. 55.

${ }^{318} \mathrm{O}$ art. 782 do Código Civil em vigor não pró́be a contratação de um novo seguro sobre o mesmo interesse, mas exige a comunicação prévia ao segurador, a fim de que o princípio indenitário previsto no art. 778 não seja desrespeitado. Essa questão será abordada no tópico 4.3.4, denominado "Pluralidade de seguros".

${ }^{319}$ Ferrarini invoca o art. 1.951, I, capov., do Código Civil italiano, que dispõe: "se os bens sujeitos a privilégio ou hipoteca são perdidos ou deteriorados, as somas devidas pelos seguradores para indenizar a perda ou a deterioração são vinculadas ao pagamento dos créditos privilegiados ou hipotecários segundo o seu grau, exceto se as mesmas forem penhoradas para reparar a perda ou a deterioração”. Explica Ferrarini que o legislador aplica à tutela dos credores privilegiados ou hipotecários o princípio da substituição real, por
} 
sentido técnico", pois os titulares dos interesses concorrentes podem fazer valer os seus direitos sobre a indenização devida pela seguradora ao proprietário do bem, caso não seja empregada para reparar a perda ou deterioração sofrida pelo bem em decorrência de um sinistro.

Mas, ressalta o autor, isso nao siginifica que, com o seguro do interesse material, sejam automaticamente segurados os interesses concorrentes, pois o seguro sobre o bem material não instaura uma relação jurídica securitária também com os titulares dos interesses concorrentes. A pretensão que o credor privilegiado ou hipotecário tem com o segurador para pleitear, no todo ou em parte (segundo o valor do seu crédito) a indenização, não nasce do contrato de seguro concluído pelo proprietário do bem hipotecado. Essa pretensão é uma pretensão autônoma do credor, que nasce ou diretamente da convenção por ele concluída com o segurador, ou da lei, que atribua de modo expresso ao credor referido direito ${ }^{320}$.

Não parece haver dúvida, portanto, de que tanto o titular do interesse material (por exemplo, o proprietário), como o titular do interesse concorrente (por exemplo: o usufrutuário, locatário ou credor hipotecário) possuem interesse legítimo para contratar o seguro. A divergência doutrinária e legislativa se coloca no momento da ocorrência do sinistro e do pagamento da indenização.

Algumas legislações trazem regras para os casos de concorrência de interesse. A nova lei de seguros portuguesa disciplina o seguro por conta própria e o seguro por conta de outrem. No primeiro caso, estabelece o inciso 2 do art. $47^{321}$ que: "se o contrário não resultar do contrato ou do conjunto de circunstâncias atendíveis,o seguro considera-se contratado por conta própria". Já o inciso 3 do mesmo artigo prevê que "Se o interesse do tomador do seguro for parcial, sendo o seguro efectuado na sua totalidade por conta própria, o contrato considera-se feito por conta de todos os interessados, salvo disposição legal ou contratual em contrário".

força do qual o bem, que constitui a garantia dos ditos credores, quando segurado pelo seu proprietário e vem a ser atingido por um sinistro, é substituído pela indenização devida pelo segurador a título de ressarcimento do dano (FERRARINI, Sergio. L'interesse nell'assicurazione, p. 61-62).

${ }^{320}$ Ibidem, p. 61-62.

321 “Artigo 47. - Seguro por conta própria

1 - No seguro por conta própria, o contrato tutela o interesse próprio do tomador do seguro.

2 - Se o contrário não resultar do contrato ou do conjunto de circunstâncias atendíveis, o seguro considera-se contratado por conta própria.

3 - Se o interesse do tomador do seguro for parcial, sendo o seguro efectuado na sua totalidade por conta própria, o contrato considera-se feito por conta de todos os interessados, salvo disposição legal ou contratual em contrário." 
Segundo o disposto na legislação portuguesa, portanto, o seguro tanto pode tutelar interesse próprio como interesse alheio. Em certas circunstâncias, ainda que contratado por conta própria, estará também garantindo o interesse de outrem. Segundo Moitinho de Almeida, há uma presunção do seguro por conta, a fim de que os titulares de interesses concorrentes sejam indenizados na proporção de seus respectivos direitos ${ }^{322}$.

É possível concluir que a previsão legislativa visa evitar que a indenização securitária seja paga a quem não é o verdadeiro titular do interesse segurável ou que possui apenas interesse parcial. Moitinho de Almeida ${ }^{323}$ invoca questão debatida no direito belga, no qual parte da doutrina defende que, mesmo sendo parcial o interesse, a indenização será paga integralmente ao contratante, o que contraria a própria função do interesse segurável de impedir que o contrato seja fonte de lucro e que indenize além do prejuizo.

O substitutivo ao Projeto de Lei n. 3.555/2004 inova positivamente ao disciplinar o seguro em favor de terceiro, prevendo de forma expressa que "o beneficiário da indenização será identificado pela lei, por ato de vontade anterior à ocorrência do sinistro ou, a qualquer tempo, pela titularidade do interesse garantido"324. E ainda: "Salvo disposição em contrário, havendo concorrência de interesses, prevalecerá a garantia por conta própria até o valor em que concorrer, valendo, naquilo que ultrapassar, como seguro em favor de terceiro, sempre respeitado o limite da importância segurada"325.

Trata-se de disposição que evidencia que o interesse identifica a pessoa legitimada não só a contratar o seguro, mas também a receber a indenização. Com acerto, Medina leciona que: “o interesse segurável condiciona a aptidão do segurado para celebrar o contrato de seguro e, por sua vez, o interesse segurado condiciona a possibilidade de cobrar a indenização. O primeiro se presume, o segundo deve ser demonstrado, ${ }^{326}$. Tzirulnik, Cavalcante e Pimentel discorrem sobre a dissociação entre o figurante do contrato e a

\footnotetext{
${ }^{322}$ MOITINHO DE ALMEIDA, J. C. O contrato de seguro no Direito Português e Comparado, p. 149.

${ }^{323}$ Ibidem, p. 148-149.

324 “Art. 21. O seguro será estipulado em favor de terceiro quando a contratação recair sobre interesse de titular distinto do estipulante, determinado ou determinável.

$\S 1^{\underline{o}} \mathrm{O}$ beneficiário será identificado pela lei, por ato de vontade anterior à ocorrência do sinistro ou, a qualquer tempo, pela titularidade do interesse garantido.

$\S 2^{\underline{0}}$ Sendo determinado o beneficiário a título oneroso, a seguradora e o estipulante deverão, tão logo quanto possível, entregar-lhe cópia da totalidade dos instrumentos que conformam o contrato de seguro."

325 "Art. 23. O seguro em favor de terceiro pode coexistir com seguro por conta própria ainda que no âmbito do mesmo contrato.

Parágrafo único. Salvo disposição em contrário, havendo concorrência de interesses, prevalecerá a garantia por conta própria até o valor em que concorrer, valendo, naquilo que ultrapassar, como seguro em favor de terceiro, sempre respeitado o limite da importância segurada."

${ }^{326}$ MAGALLANES, Pablo Medina. O interesse segurável. In: III FÓRUM DE DIREITO DO SEGURO, p. 382 .
} 
pessoa do segurado, entendendo que é possível aplicar a gestão de negócios, "por conexidade de interesses" ${ }^{\text {327 }}$. Na prática brasileira, a questão se resolve, na maioria das vezes, pela inserção de cláusulas beneficiárias nas apólices, já que o Código Civil não traz disposição específica sobre o tema ${ }^{328}$.

\subsubsection{Interesse sobre lucro}

Segundo Ferrarini, “interesse e dano são grandezas correspondentes. Concretizando-se o sinistro, o dano se substitui ao interesse: isso que antes era interesse é agora dano"329. Pode-se dizer, assim, que, no seguro de coisa, um dano que atinja o patrimônio na sua matéria corresponde a um interesse material ou concorrente, e o dano que inviabilize auferir a vantagem que esse bem propicia, a um interesse sobre lucro.

O objeto do interesse, seja no interesse material, seja no interesse sobre lucro, continua a ser o bem. A vantagem é uma consequência da relação entre o interessado e o bem do qual se tira proveito e representa o valor do lucro, não o objeto do interesse. O que muda, portanto, é a relação.

Não basta, porém, a existência de uma chance de se extrair do bem um proveito. Somente aquele que tenha uma fundada expectativa de extrair uma vantagem do bem com o seu uso é que tem o interesse sobre lucro, estando legitimada a contratação desse tipo de $\operatorname{risco}^{330}$.

\footnotetext{
${ }^{327}$ Cf. TZIRULNIK, Ernesto; CAVALCANTI, Flávio de Queiroz B.; PIMENTEL, Ayrton. O contrato de seguro no novo Código Civil brasileiro, p. 33-34.

${ }^{328}$ Sobre o tema, interessante é a decisão do Superior Tribunal de Justiça (STJ), que, mesmo sem fazer alusão direta ao interesse segurável, prestigiou a sua função no contrato de seguro:

"Ressarcindo a seguradora o proprietário os prejuízos relativos à perda total do bem locado em decorrência de incêndio e dele recebido quitação, é descabido o pleito do locatário no sentido de receber a totalidade da indenização, ainda que o seguro tenha sido estipulado a seu favor, por encerrar hipótese de enriquecimento sem causa.

Vale ressaltar, nesse passo, que a perda do bem locado não traduz qualquer diminuição do patrimônio do inquilino, o que reforça a falta de plausibilidade do argumento de que a ele deve ser dirigida a indenização, mormente quando já paga por quem experimentado efetivamente o prejuízo" (REsp 734135 - Rel. Ministro Fernando Çonçalves, j. 03/03/2008).

${ }^{329}$ FERRARINI, Sergio. L'interesse nell'assicurazione, p. 70-71.

${ }^{330}$ Nesse sentido, aplica-se o mesmo critério utilizado no Direito Civil, conforme ensinamento de Aguiar Dias: "O critério acertado está em condicionar o lucro cessante a uma probabilidade objetiva resultante do desenvolvimento normal dos acontecimentos conjugados às circunstâncias peculiares ao caso concreto" (AGUIAR DIAS, José. Da responsabilidade civil. 3. ed. Rio de Janeiro: Forense, 1954. t. 2, p. 713).
} 
Em regra, o interesse material e sobre lucro são independentes, de maneira que a contratação da garantia sobre o primeiro não abrange a garantia sobre o segundo.

$\mathrm{Na}$ doutrina estrangeira, autores como Hagen, citado por Ferrarini ${ }^{331}$, negam que o interesse sobre lucro seja independente. Para esses autores, essa espécie de interesse nada mais é do que uma parte do dano em sentido lato, integrando o interesse material.

Ferrarini rechaça a opinião apontada e destaca que o interesse sobre material e sobre o lucro pode ser de pessoas diversas e, ademais, a perda do lucro pode ocorrer mesmo sem a perda do bem. É o caso das mercadorias que, mesmo intactas, chegam em local diverso ou fora do prazo esperado, ocasionando a perda total ou parcial do lucro que não se relaciona com a perda do bem e, sim, com a impossibilidade de sua utilização. $O$ autor italiano dá o seguinte exemplo: imagine-se mercadorias esperadas para a venda em época de Natal que chegam ao destino apenas em janeiro, no período de férias. Veja-se que é possível segurar o próprio processo de obtenção do lucro contra riscos que não ameaçam necessariamente o bem, mas sim o processo do qual se extrai o lucro ${ }^{332}$.

O art. 779 do Código Civil dispõe que: "O risco do seguro compreenderá todos os prejuízos resultantes ou consequentes, como sejam os estragos ocasionados para evitar o sinistro, minorar o dano, ou salvar a coisa".

Referida disposição legal não constava do anteprojeto de Comparato e repete o art. 1.461 do Código Civil de $1916^{333}$, com a única diferença de ter excluído a expressão inicial: "salvo expressa restrição na apólice". A doutrina diverge sobre os efeitos da alteração legislativa.

Conforme Delgado ${ }^{334}$, o objetivo da norma é justamente exigir a conduta do segurado no sentido de adotar todas as providências necessárias para salvar o bem segurado ou diminuir o prejuízo sofrido. A alteração feita no Código de 2002 demonstra apenas que não é mais possível a restrição de cobertura para os prejuízos incorridos na tentativa de salvamento do bem. Não se trata, porém, de estender a cobertura securitária para os danos indiretamente decorrentes do sinistro, como é o caso dos lucros cessantes, salvo se houver previsão contratual expressa.

\footnotetext{
${ }^{331}$ FERRARINI, Sergio. L'interesse nell'assicurazione, p. 67.

332 Ibidem, p. 68.

${ }^{333}$ Art. 1.461 do Código Civil de 1916: "Salvo expressa restrição na apólice, o risco do seguro compreenderá todos os prejuízos resultantes ou consequentes, como sejam os estragos ocasionados para evitar o sinistro, minorar o dano ou salvar a coisa".

${ }^{334}$ DELGADO, José Augusto. Comentários ao novo Código Civil, v. XI, p. 432.
} 
Essa já era a lição de Carvalho Santos, em comentário ao art. 1.461 do Código anterior:

"Mas, evidentemente, não mais seria razoável, a não ser mediante cláusula expressa nesse sentido, submeter o segurador a indenizar ao segurado os prejuízos que ele vier a sofrer como consequência mediata do sinistro, as perdas que este lhe pudesse ter causado, como, por exemplo, as perdas resultantes da paralisação da atividade profissional ou comercial do segurado, etc." 335 .

Em comentários especificamente ao art. 779 do novo Código, Alvim e Tepedino sustentam no mesmo sentido:

"Porém, a não ser em havendo cláusula expressa nesse sentido, não se poderia obrigar o segurador a indenizar o segurado pelos prejuízos que aquele venha a sofrer como consequência mediata do sinistro, tais quais as perdas resultantes da paralisação da atividade profissional ou comercial do segurado" 336 .

"O segurador não dá cobertura a todos esses riscos, salvo se constarem expressamente do contrato. No citado exemplo de um sinistro-incêndio, a apólice não abrange os danos indiretos que poderão, no entanto, ser objeto de outros seguros, como o de perda de ponto, lucro cessante, etc." 337 .

Já para Tzirulnik, Cavalcanti e Pimentel, a exclusão da expressão "salvo expressa restrição da apólice" indica que, "em princípio, a garantia é dirigida para todos os riscos, mas é evidente que o contrato pode restringi-la por meio da predeterminação dos riscos"338.

${ }^{335}$ CARVAlho SANTOS, J. M. de. Código Civil brasileiro interpretado. 7. ed. Rio de Janeiro: Freitas Bastos, 1960. v. 19, p. 372.

${ }^{336}$ TEPEDINO, Gustavo; BARBOZA, Heloisa Helena; MORAES, Maria Celina Bodin de. Código Civil interpretado: conforme a Constituição da República. Rio de Janeiro: Renovar, 2006. v. 2, p. 587.

${ }^{337}$ ALVIM, Pedro. O seguro e o novo Código Civil. Organização e compilação de Elizabeth Alvim Bonfioli. Rio de Janeiro: Forense, 2007. p. 100.

${ }^{338}$ TZIRULNIK, Ernesto; CAVALCANTI, Flávio de Queiroz B.; PIMENTEL, Ayrton. O contrato de seguro no novo Código Civil brasileiro, p. 108. 
Na prática securitária brasileira, os lucros cessantes são expressamente excluídos da cobertura para danos materiais, salvo se contratada a garantia específica para esse fim ${ }^{339}$, que abrange não só a perda de receita, mas também as despesas fixas que permanecem sem a contrapartida do lucro ${ }^{340}$, bem como os gastos adicionais ou extraordinários realizados pelo segurado com o intuito de diminuir ou evitar a perda de receita.

\subsection{Interesse e valor segurável}

Nos termos dos arts. $778^{341}$ e $781^{342}$ do Código Civil, o interesse determina o valor segurável e o valor indenizável. O valor (do interesse) segurável é o prejuízo máximo a que o interesse está sujeito. Valor indenizável é o prejuízo efetivamente sofrido em decorrência do sinistro. O objetivo é que exista uma equivalência entre o valor segurável, o prejuízo sofrido e a indenização securitária, a fim de evitar que o seguro seja uma fonte de lucro para o segurado, em obediência ao princípio indenitário, já referido ${ }^{343}$.

\footnotetext{
339 Veja-se a definição constante do Dicionário de Seguros do IRB Brasil Resseguros S/A: "SEGURO LUCROS CESSANTES - destina-se a pessoas jurídicas (indústria, comércio e prestadores de serviço). Tem como objetivo a preservação do movimento de negócios do segurado, a fim de manter sua operacionalidade e lucratividade nos mesmos níveis anteriores à ocorrência de um sinistro. A garantia concedida por esse seguro tem início imediatamente após a ocorrência do sinistro e está limitada ao número de meses estabelecido pelo segurado ('período indenitário'), que deverá corresponder ao tempo necessário para o retorno ao nível normal do movimento de negócios da empresa. A cobertura básica abrange as Despesas Fixas: aquelas que perduram após o evento, independentemente do nível de produção/vendas; o Lucro Líquido: lucro decorrente da operação principal do Segurado; e os Gastos Adicionais: despesas efetuadas pelo Segurado para reduzir ou evitar a queda do movimento de negócios". (Disponível em: <http://www.irb-brasilre.com.br>. Acesso em: 15 fev. 2010.)

${ }^{340}$ O "seguro de lucro bruto" cobre não apenas o lucro líquido, mas também as despesas fixas. Conforme Ferrarini, para se extrair do bem um lucro, em geral é necessário arcar com as despesas de uso do bem. As despesas, porém, são compensadas pelo maior valor que se adquire com a sua realização. O seguro abrange, em regra, um e outro e é chamado de seguro de lucro bruto, contemplando tanto um interesse material como um interesse sobre lucro (FERRARINI, Sergio. L'interesse nell'assicurazione, p.74).

341 “Art. 778. Nos seguros de dano, a garantia prometida não pode ultrapassar o valor do interesse segurado no momento da conclusão do contrato, sob pena do disposto no art. 766, e sem prejuízo da ação penal que no caso couber."

342 "Art. 781. A indenização não pode ultrapassar o valor do interesse segurado no momento do sinistro, e, em hipótese alguma, o limite máximo da garantia fixado na apólice, salvo em caso de mora do segurador."

${ }^{343}$ Sobre o tema, ressalta Mello Franco: "Esta norma [do art. 778] deve ser completada por aquela do art. 781, quando limita o montante da indenização ao valor do interesse segurado no momento do sinistro. Temse, com isso, a plena aplicação do princípio indenitário, evitando, por qualquer forma, que o seguro possa ser uma fonte de renda para o segurado" (MELLO FRANCO, Vera Helena de. Breves reflexões sobre o contrato de seguro no novo Código Civil brasileiro. In: FÓRUM DE DIREITO DO SEGURO JOSÉ SOLLERO FILHO, 2., 2001, São Paulo. II Fórum de direito do seguro. (Estudos de direito do seguro). São Paulo: Instituto Brasileiro de Direito do Seguro, 2002. p. 448, v. 4.
} 
No caso de uma desproporção entre o valor do interesse, o valor segurado e a indenização securitária, haverá sobresseguro (se o valor segurado for maior que o valor do interesse) ou infrasseguro ${ }^{344}$ (se o valor segurado for menor do que o valor do interesse). Ainda, e em razão desse princípio indenitário, há restrições para a pluralidade de seguros para o mesmo interesse e sobre o mesmo risco.

O princípio indenitário deve atuar, no entanto, igualmente para ambas as partes no contrato de seguro: nem o segurado pode receber mais do que tem direito, nem o segurador deve pagar menos do que o devido ${ }^{345}$.

\subsubsection{Atribuição do valor do interesse}

O valor segurado é aquele que se atribui ao interesse segurado pelo contratante ao celebrar o contrato ${ }^{346}$. Discute-se na doutrina quais seriam os critérios para essa valoração. Conforme Mello Franco ${ }^{347}$, o valor do interesse pode ser aferido tanto por um critério subjetivo, atribuído pelo próprio indivíduo em função de sua necessidade, como por um critério objetivo, ou seja, pelo valor do bem no mercado.

\footnotetext{
${ }^{344}$ Também chamado de subseguro, conforme MELLO FRANCO, Vera Helena de. Breves reflexões sobre o contrato de seguro no novo Código Civil brasileiro. In: FÓRUM DE DIREITO DO SEGURO JOSÉ SOLLERO FILHO, p. 448-449.

${ }^{345}$ Nesse ponto, vale referir decisão da Corte australiana no caso Castelain vs. Preston: "The very foundation, in my opinion, of every rule which has been applied to insurance Law is this, namely, that the contract of insurance contained in a marine or fire policy is a contract of indemnity, and of indemnity only, and that this contract means that the assured, in case of a loss against which the policy has been made, shall be fully indemnified, but shall never be more than fully indemnified. That is the fundamental principle of insurance, and if ever a proposition is brought forward which is a variance with it, that is to say, which either will prevent the assured from obtaining a full indemnity, or which will give the assured more than a full indemnity, that proposition must certainly be wrong" (Austrália-Castellain vs. Preston (1882-1883) L.R 11 QBD 380). Tradução livre: “A verdadeira fundamentação, na minha opinião, de qualquer regra que tenha aplicação na lei de seguro é essa, ou seja, de que o contrato contido numa apólice de seguro marítimo ou de incêndio é um contrato de indenização e de indenização apenas, e que esse contrato significa que o segurado, em caso de ocorrência da perda contra a qual a apólice foi contratada, deve ser indenizado integralmente, mas nunca deverá ser mais do que plenamente indenizado. Este é o princípio fundamental do seguro, e se alguma vez uma proposição é colocada em contradição com tal princípio, ou seja, impedindo o segurado de obter uma indenização total, ou conferindo ao segurado mais do que uma indenização integral, certamente tal proposição deve estar errada" (Austrália-Castellain vs. Preston (1882-1883) L.R 11 QBD 380).

${ }^{346}$ MELLO FRANCO, Vera Helena de, op. cit., p. 442.

${ }^{347}$ Idem. Contratos no Direito Privado: direito civil e comercial, p. 305.
} 
Segundo Ferrarini, porém, o que determina o valor do seguro é o valor da relação entre uma pessoa e um bem, não o valor do bem, objeto da relação. É verdade que o valor do interesse e o do objeto podem coincidir, mas nem sempre.

Conforme assinalado, o valor do bem objetivamente considerado (como unidade material) não se altera, permanecendo o mesmo independentemente da relação da qual é objeto. Já a relação se modifica de acordo com as várias espécies de vínculos que ligam o bem ao sujeito; porém, o valor dessa relação é objetivo e não se estabelece pelo valor atribuído pelo sujeito ${ }^{348}$.

Ferrarini admite, no entanto, que esse princípio pode ser validamente descumprido em algumas circunstâncias, já que há casos em que a relação econômica entre uma pessoa e um bem tem uma utilidade particular, de forma que o valor subjetivo é superior ao valor da relação objetivamente considerada - uma coleção de carros, por exemplo.

Ainda, Ferrarini distingue o valor objetivo do valor do interesse propriamente dito. Ressalva que, apesar de coincidirem na maioria das vezes, não se identificam um com o outro. Na verdade, considerando que se entende por interesse a relação entre uma pessoa e um bem ameaçado por um risco determinado, conclui-se que o valor da relação será o valor do interesse apenas "enquanto e na medida em que é ameaçada por um risco",349.

Para se estabelecer o valor do interesse é, portanto, necessário verificar o valor econômico objetivo da relação entre a pessoa e o bem, passível de ser destruído por um risco. E é esse valor do interesse que constitui o valor segurável, ou seja, o valor considerado como limite de indenização pelo segurador.

Em rigor, o valor do interesse segurado não é alterado durante a vigência do contrato, salvo se pactuada sua revisão; todavia, a indenização sempre será fixada de acordo com um critério objetivo, lembrando que o valor do interesse não determina o valor indenizável, mas apenas o limite de responsabilidade do segurador em caso de sinistro.

\footnotetext{
${ }^{348}$ Cf. FERRARINI, Sergio. L'interesse nell'assicurazione, p. 34.

${ }^{349}$ Ibidem, p. 35.
} 


\subsubsection{Sobresseguro}

O sobresseguro tem lugar quando a soma segurada excede o valor do interesse segurável.

Conforme lição de Carvalho Santos, "se o valor atribuído ao interesse segurado for exagerado, passa a haver especulação, ao invés de indenização" ${ }^{\text {,350 }}$. Na mesma toada, Delgado assinala que o objetivo do legislador é evitar que o seguro se transforme em fonte de lucro para o segurado ${ }^{351}$.

O Código Civil de 2002 traz disposição expressa a esse respeito, vedando o sobresseguro no art. 778 do Código Civil, que determina, desde a conclusão do contrato, a necessária equivalência entre o valor do interesse segurado e a garantia prometida, sob pena de aplicação das sanções previstas no art. 766 do mesmo diploma legal, que trata sobre o dever de informação do segurado.

No Código de 1916, o sobresseguro vinha previsto nos arts. 1.437 e 1.438 com a seguinte redação:

“Art. 1437. Não se pode segurar uma coisa por mais do que valha, nem pelo seu todo mais de uma vez. Todavia, é lícito ao segurado acautelar, mediante novo seguro, o risco de falência ou insolvência do segurador (art. 1439).

Art. 1438. Se o valor do seguro exceder ao da coisa, o segurador poderá, ainda depois de entregue a apólice, exigir a sua redução ao valor real, restituindo ao segurado o excesso do prêmio; e, provando que o segurado obrou de má-fé, terá direito a anular o seguro, sem restituição do prêmio, nem prejuízo da ação penal que no caso couber".

A redação prevista no Código vigente tem suscitado interpretações divergentes por parte da doutrina. Para Delgado, o art. 788 do Código Civil considera nulo, de pleno

${ }^{350}$ CARVALHO SANTOS, J. M. de. Código Civil brasileiro interpretado, p. 269. In: TEPEDINO, Gustavo; BARBOZA, Heloisa Helena; MORAES, Maria Celina Bodin de. Código Civil Interpretado: conforme a Constituição da República, v. II, p. 585.

${ }^{351}$ DELGADO, José Augusto. Comentários ao novo Código Civil, p. 413. 
direito, o contrato pelo simples fato da soma segurada ultrapassar o valor do interesse segurável. O autor prossegue aduzindo que, diferentemente da legislação anterior, não há, na nova lei, a distinção entre o contrato celebrado com dolo ou fraude e aquele firmado sem tais vícios ${ }^{352}$.

De fato, enquanto o Código atual utiliza a expressão "não pode ultrapassar", o antigo art. 1.438 admitia expressamente a possibilidade de excesso de seguro ao dispor: "Se o valor do seguro exceder ao da coisa [...]"353; todavia, também o art. 1.437 continha a expressa vedação ao sobresseguro ao determinar que "não se pode segurar uma coisa por mais que o valha".

A remissão ao art. 766 indica, assim, que a sanção pelo sobresseguro é a mesma para a declaração inexata e dependerá da demonstração da boa-fé ou má-fé do segurado ao atribuir um valor excessivo ao interesse segurável. O caput do referido artigo prevê a perda do direito à garantia e ao pagamento do prêmio vencido, nos casos em que o segurado agir de má-fé. Quando não ficar demonstrada a má-fé do segurado, tem aplicação o parágrafo único, pelo qual "o segurador terá direito de resolver o contrato, ou a cobrar, mesmo após o sinistro, a diferença de prêmio".

De fato, não se poderia presumir que o sobresseguro é sempre fruto da má-fé do segurado. Como demonstrado, há seguros, como o de lucros cessantes, cujo valor segurado é sempre fixado por estimativa, estando portanto (o valor segurável) sujeito a alterações involuntárias das partes; ademais, conforme adverte Alvim ${ }^{354}$, mesmo o interesse material pode sofrer alteração ao longo do tempo, para mais ou para menos. Apesar da depreciação ser o efeito mais comum, não é necessariamente uma regra.

Aliás, segundo o autor em comento: "A prática tem demonstrado que é de toda conveniência para o segurado, ao estimar o valor do seguro, aumentá-lo para atender as circunstâncias diversas" ${ }^{355}$. Alvim faz referência ao já comentado art. 779, segundo o qual as despesas de salvamento consequentes de um sinistro deverão ser reembolsadas pelo segurador, que utilizará, para tanto, o limite da garantia.

\footnotetext{
${ }^{352}$ DELGADO, José Augusto. Comentários ao novo Código Civil, p. 413.

${ }^{353}$ Nesse sentido, ensina Pontes de Miranda: "A despeito do art. 1437 do Código Civil, pode dar-se que se faça o seguro além do valor do bem". É o que se prevê no art. 1438 [...]” (PONTES DE MIRANDA, Francisco Cavalcante. Tratado de Direito Privado, t. XLV, p. 345/346).

${ }_{354}$ ALVIM, Pedro. O seguro e o novo Código Civil, p. 97-98.

${ }^{355}$ Ibidem, p. 97.
} 
É forçoso concluir que, nos casos em que o excesso de seguro não resultar da má-fé do segurado, deve ser aplicado o previsto no parágrafo único do art. $766^{356,357}$. Nessa hipótese, o contrato produz efeitos, mas a indenização será necessariamente limitada ao valor do interesse segurado no momento do sinistro, por força do art. 781 do Código Civil, sendo facultado, porém, ao segurador cobrar a diferença do prêmio ${ }^{358}$. Se não houve sinistro, o segurador poderá resolver o contrato antecipadamente.

O Código de 2002 é omisso se, nesse caso, o segurado está obrigado ou não à devolução proporcional do prêmio; todavia, a redação do art. 1.438 do Código Civil de 1916, bem como o art. 884 do Código Civil atual indicam que o segurador não poderia deixar de restituir o prêmio, sob pena de enriquecimento ilícito ${ }^{359}$.

Interessante a solução adotada pela Lei argentina n. 17.418/1967, que prevê o sobresseguro apenas nos casos em que a soma segurada supere notavelmente o valor atual

\footnotetext{
${ }^{356}$ Nesse sentido é a opinião de Tzirulnik, Cavalcanti e Pimentel: "O desequilibrio entre o interesse e a garantia pode decorrer de ato to segurado, de terceiros ou mesmo de ato da seguradora. Caso o desequilíbrio seja provocado pelo segurado com a intenção de obter alguma vantagem, a norma prevê a incidência do art. 766, que trata da perda do direito à garantia, tenha ou não ocorrido o sinistro. A ação penal a que faz menção o dispositivo é pública, pela prática de estelionato" (TZIRULNIK, Ernesto; CAVALCANTI, Flávio de Queiroz B.; PIMENTEL, Ayrton. O contrato de seguro no novo Código Civil, p. 104.). Também nessa trilha é a opinião de TEPEDINO, Gustavo; BARBOZA, Heloisa Helena; MORAES, Maria Celina Bodin de. Código Civil interpretado: conforme a Constituição da República, p. 585-586.

${ }^{357}$ Note-se que o parágrafo único do art. 766 também gerou interpretações diversas na doutrina, sobre a possibilidade do segurador resolver o contrato, sem o pagamento da indenização. A Superintendência de Seguros Privados (Susep), editou a circular n. 256/2004, explicitando claramente que, ausente a má-fé, não pode o segurador furtar-se ao pagamento da indenização:

“Art. 37. Deverá constar das condições contratuais que, se o segurado, seu representante legal, ou seu corretor de seguros, fizer declarações inexatas ou omitir circunstâncias que possam influir na aceitação da proposta ou no valor do prêmio, ficará prejudicado o direito à indenização, além de estar o segurado obrigado ao pagamento do prêmio vencido.

Parágrafo único. Se a inexatidão ou a omissão nas declarações não resultar de má-fé do segurado, a sociedade seguradora poderá:

I - na hipótese de não ocorrência do sinistro:

a) cancelar o seguro, retendo, do prêmio originalmente pactuado, a parcela proporcional ao tempo decorrido; ou

b) permitir a continuidade do seguro, cobrando a diferença de prêmio cabível.

II - na hipótese de ocorrência de sinistro sem indenização integral:

a) cancelar o seguro, após o pagamento da indenização, retendo, do prêmio originalmente pactuado, acrescido da diferença cabível, a parcela calculada proporcionalmente ao tempo decorrido; ou

b) permitir a continuidade do seguro, cobrando a diferença de prêmio cabível ou deduzindo-a do valor a ser indenizado.

III - na hipótese de ocorrência de sinistro com indenização integral, cancelar o seguro, após o pagamento da indenização, deduzindo, do valor a ser indenizado, a diferença de prêmio cabível."

${ }^{358}$ É preciso atentar-se para o desvio da Jurisprudência, ao determinar o pagamento da soma segurada, nos casos de perda total, ainda que o prejuízo seja inferior - ver art. 781 e DELGADO, José Augusto. Comentários ao novo Código Civil, p. 457-462.

359 Também essa é a opinião de TZIRULNIK, Ernesto; CAVALCANTI, Flávio de Queiroz B.; PIMENTEL, Ayrton, op. cit., p. 104.
} 
do interesse segurado, permitindo às partes requerer a sua redução, salvo na hipótese de má-fé do segurado, quando o seguro será considerado nulo:

“"Art. 62. Si la suma segurada supera notablemente el valor actual del interés asegurado, el asegurador o el tomador pueden requerir su reducción'. El contrato és nulo si se celebró con la intención de enriquecerse indebidamente con el excedente el segurado. Si a la celebración del contrato el segurador no conocía esa intención, tiene derecho a percibir la prima por el período de seguro durante el cual adquiere este conocimiento".

Já o art. 65 da referida Lei argentina dispõe que, se não houve a redução prevista no artigo anterior, em caso de sinistro, a seguradora estará obrigada a pagar apenas o prejuízo efetivamente sofrido, mas terá direito à integralidade do prêmio:

\begin{abstract}
“Art. 65. Si al tiempo del siniestro el valor asegurado excede del valor asegurable, el asegurador sólo está obligado a resarcir el perjuicio efectivamente sufrido; no obstante tiene derecho a percibir la totalidade de la prima".
\end{abstract}

No Brasil, porém, nos casos de perda total, o entendimento jurisprudencial ${ }^{360}$ tem sido no sentido de obrigar o segurador ao pagamento do valor do interesse segurado, independentemente do valor do prejuízo, diante da previsão do art. 1.462 do Código Civil de $1916^{361}$. Apesar de o novo diploma legal ser expresso sobre o limite da indenização ao valor do prejuízo, ainda não houve uma mudança da tendência jurisprudencial, o que demonstra como o tema ainda é pouco compreendido pelos tribunais brasileiros.

\footnotetext{
360 "Verificada a perda total do bem objeto de contrato de seguro, deve o segurado ser indenizado pelo valor constante da apólice. [...] A conclusão do TJGO está em consonância com a jurisprudência firmada no STJ sobre o tema, a qual considera que, nos casos de perda total do bem segurado, o valor dado à apólice constitui não apenas o limite estipulado em favor do segurador para o ressarcimento dos prejuízos sofridos pelo segurado, mas também a própria predeterminação do valor do bem objeto do contrato (CC, art. 1462), o que torna devida a indenização por tal valor (da apólice), e não pelo efetivo prejuízo sofrido pelo segurado." (AgRg no Ag 544354 / GO, Rel. Min. Nacy Andrighi j.16/03/2004).

${ }^{361}$ "Art. 1.462. Quando ao objeto do contrato se der valor determinado, e o seguro se fizer por este valor, ficará o segurador obrigado, no caso de perda total, a pagar pelo valor ajustado a importância da indenização, sem perder por isso o direito, que lhe asseguram os arts. 1.438 e 1.439."
} 


\subsubsection{Infrasseguro: a cláusula de rateio ou regra proporcional}

O infrasseguro (ou subseguro), como o próprio nome indica, tem lugar quando o valor da garantia é inferior ao valor do interesse.

Diverso do sobresseguro, o infrasseguro não é vedado por lei, uma vez que não desnatura o contrato de seguro ao tornar o sinistro vantajoso. Ao contrário, no momento do pagamento da indenização, tem aplicação a regra proporcional ou rateio, pela qual o segurado responde proporcionalmente à diferença entre o valor segurado e o valor segurável. O fundamento da regra proporcional é a desproporção entre o prêmio e o risco.

$\mathrm{O}$ rateio somente produz efeitos no momento do sinistro e desde que as perdas sejam parciais. Em se tratando de perda total, a soma segurada é devida na íntegra.

Ao contrário da legislação anterior que não trazia qualquer disposição sobre o infrasseguro, o Código Civil de 2002 abordou de modo expresso o tema no art. 783: "Salvo disposição em contrário, o seguro de um interesse por menor do que valha acarreta a redução proporcional da indenização, no caso de sinistro parcial".

A diferença entre o valor do interesse e o valor da soma segurada pode tanto ocorrer desde a celebração do contrato, como se verificar durante o período de vigência deste. A insuficiência de garantia pode resultar da vontade do segurado, que opta pela realização de um seguro de valor mais baixo, de um erro involuntário de avaliação do interesse, ou, ainda, da modificação do valor do interesse no curso do contrato.

O infrasseguro somente tem lugar, portanto, nos seguros de dano direto, que permitem seja estabelecido o valor objetivo do interesse e, por consequência, do limite máximo de garantia. Não se pode cogitar de infrasseguro nos seguros de responsabilidade civil (danos indiretos), já que não é possível fixar o dano máximo possível de se causar a um terceiro, tampouco nos seguros de pessoas, em que a garantia é livremente contratada, por não se tratar de um seguro de indenização.

Ressalte-se que, todavia, mesmo nos seguros diretos, há interesses que não comportam uma avaliação objetiva, mas apenas uma estimativa. É o caso do seguro de lucros cessantes, que sempre serão fixados por aproximação, já que se trata de uma expectativa de ganho futuro. Nesses casos, a cláusula de rateio pode onerar em demasia o segurado que poderá ter sua indenização securitária reduzida, quando o aumento do valor 
do interesse no curso do contrato independe de sua vontade e, na verdade, constitui um fato positivo, pois demonstra que houve um aumento do lucro esperado.

Moitinho de Almeida, ao comentar o art. $134^{\circ}$ da recente Lei de Seguros portuguesa, traça um panorama sobre o subseguro e a regra proporcional em vários países, salientando que:

\begin{abstract}
"Essa regra proporcional, no direito inglês correspondente ao princípio payment subject to average, e que, na prática só em caso de sinistro parcial tem relevância (o sinistro total tem como limite a quantia segura) justifica-se pela insuficiência do prêmio: no respectivo cálculo tem-se em consideração não só a frequência dos sinistros como também a importância média destes que depende do valor da coisa segura. Colhe, porém, frequentemente os segurados de surpresa, vítimas de erro de avaliação ou desatentos à evolução do valor da coisa segura. Por isso, em França, a comissão que se ocupa das cláusulas abusivas propôs a supressão da regra proporcional nos seguros multirriscos habitação, e, em Inglaterra não vigora, salvo cláusula em contrário, nos seguros contra incêndio e provavelmente noutros. O Projeto de Lei brasileiro n. 3.555/2004, indo demasiado longe, afasta-a expressamente (art. 95) e a recente lei alemã faz depender a sua aplicação da existência de uma diferença considerável da quantia segura relativamente ao valor do objeto seguro no momento do sinistro" ${ }^{, 32}$.
\end{abstract}

De acordo com o substitutivo aprovado na Comissão de Desenvolvimento Econômico, Indústria e Comércio, em julho de 2008, para o Projeto de Lei n. 3.555/2004 em tramitação no Congresso Nacional, o art. 95 não exclui o rateio, mas em vez de deixálo como regra, coloca a regra proporcional como exceção. Ademais, obriga a seguradora a exemplificar o cálculo na apólice e limita o rateio ao infrasseguro superveniente, salvo em caso de ato voluntário do segurado de redução da soma segurada.

362 AlmeidA, J. C. Moitinho de. Contrato de seguro: estudos. Coimbra: Coimbra, 2009. p. 23-24. 
“Art. 95. Na hipótese de sinistro parcial, o valor da indenização devida não será objeto de rateio em razão de seguro contratado por valor inferior ao do interesse, salvo disposição em contrário.

$\S 1^{\underline{o}}$. Quando pactuado o rateio, a seguradora exemplificará na apólice a fórmula para cálculo da indenização.

$\S 2^{\underline{o}}$. A aplicação do rateio em função de infra-seguro superveniente será limitada aos casos em que o aumento do valor do interesse decorrer de ato voluntário do segurado".

Entende-se que seja acertada a proposta de alteração legislativa. Apesar de a aplicação da regra proporcional ser comum e configurar prática consagrada no mercado securitário, é de difícil compreensão para o segurado; ademais, sua aplicação somente faz sentido quando, no momento da celebração do contrato, o valor segurado é inferior ao valor segurável. O segurado não pode ser prejudicado quando a alteração do valor segurável se deu no decorrer da contratação, por fato alheio a sua vontade ou atuação.

\subsubsection{Pluralidade de seguros}

A realização de mais de um seguro sobre o mesmo interesse deve respeitar o princípio indenitário. Caracteriza-se a pluralidade de seguros quando se cobre o mesmo interesse, contra o mesmo risco, pelo mesmo prazo, com seguradores diferentes ${ }^{363}$.

O art. 782 do Código Civil de 2002 não veda a contratação de um novo seguro sobre o mesmo interesse, mas determina que haja uma comunicação prévia ao primeiro segurador, indicando a soma segurada pretendida, a fim de que a garantia não exceda o valor do interesse:

“Art. 782. O segurado que, na vigência do contrato, pretende obter novo seguro sobre o mesmo interesse, e contra o mesmo risco junto a outro segurador, deve previamente comunicar sua intenção por

\footnotetext{
${ }^{363}$ Conforme HALPERIN, Isaac. El contrato de seguro, p. 450.
} 
escrito ao primeiro, indicando a soma por que pretende segurar-se, a fim de se comprovar a obediência ao disposto no art. 778".

É necessário, portanto, comparar o valor de cada garantia ao interesse segurável. Se a soma das garantias for igual ao interesse segurável, caracteriza-se um seguro total - e, nesse caso, cada contrato será de infrasseguro -; se, porém, a soma das garantias superar o interesse segurável, haverá sobresseguro.

Depreende-se do texto legal que não há vedação ao segundo seguro e sim ao sobresseguro, ou seja, a contratação de seguros cumulativos sobre o mesmo interesse e sobre o mesmo risco, cujas garantias somadas ultrapassem o valor do interesse segurável. Também aqui é cristalina a intenção do legislador de, prestigiando o princípio indenitário, impedir que o sinistro se mostre vantajoso ao segurado, garantindo-lhe o recebimento de uma indenização superior ao valor real do interesse ${ }^{364}$.

Além do princípio indenitário, o dever de comunicação da norma é reflexo do próprio dever de boa-fé previsto no art. 782 do Código Civil de $2002^{365}$. Observa, porém, Tzirulnik, ${ }^{366}$ que o referido dispositivo não prevê qualquer forma especial para tanto.

Na Código Civil de 1916, a questão era tratada nos arts. 1.437 e 1.439 . O primeiro dispunha que não se pode segurar uma coisa pelo seu todo mais que uma vez, salvo quando se tratar do risco de insolvência do segurador; o segundo, por sua vez, previa justamente que, excetuada a hipótese de seguro de insolvência prevista no art. 1.437, o seguro da coisa já segura pelo mesmo risco e no seu valor integral poderia ser anulado por qualquer das partes. Nesse último caso, o segundo segurador, que não tivesse ciência do contrato anterior, poderia negar o pagamento da indenização ou pedir a repetição do indébito no que excedesse ao valor do bem, mantendo para si o prêmio pago.

O Código Civil atual, conforme assinalado, adotou uma solução inversa à da legislação pretérita: agora, o dever de comunicação é ao primeiro segurador. A legislação, porém, não é clara sobre as consequências da contratação do segundo seguro, ainda que cumprida a obrigação de aviso prévio ao segurador primitivo.

\footnotetext{
${ }^{364}$ DELGADO, José Augusto. Comentários ao novo Código Civil, p. 474.

${ }^{365}$ Ibidem, p. 475

366 Ibidem, p. 114.
} 
A preocupação do legislador, como observado, refere-se não à contratação de um novo seguro, mas ao fato de que as somas seguradas contratadas signifiquem uma garantia superior ao valor do interesse no momento da conclusão do contrato. Se, portanto, o primeiro seguro foi de valor inferior ao do interesse (infrasseguro) ou, ainda, no decorrer do primeiro contrato, o interesse teve seu valor aumentado, não haverá qualquer consequência para os contratos, que poderão coexistir, na medida em que as somas seguradas não ultrapassem o valor do interesse. Nesse caso, os contratos funcionam como se fossem um só.

Parte expressiva da doutrina entende, porém, que, na hipótese de a soma das garantias de ambos os contratos ultrapassar o valor do interesse, o primeiro contrato perde seu objeto relativamente ao excesso de seguro.

"O novo contrato, garantido nos mesmos termos, faz desaparecer o objeto do antigo seguro, ao menos na parte em que a soma dos valores das duas garantias ultrapasse o valor do interesse legítimo do segurado. Há perecimento de objeto, e a comunicação se faz à primeira seguradora, para que ela tenha ciência do novo contrato de seguro, e do perecimento total ou parcial do objeto do contrato. A constatação do perecimento do objeto contratual se faz pelo exame da soma que irá o segurador contratar e do risco a ser coberto. $\mathrm{Na}$ dicção legal, 'a fim de se comprovar a obediência ao disposto no art. $778^{,, 367 . ~}$

Entende, ainda, parte da doutrina, que a determinação do cumprimento ao art. 778 não significa a sujeição às penalidades previstas no art. 766, já que não há ilicitude na nova contratação, mas perecimento do primeiro contrato, em caso de excesso de garantia. Por isso, não há previsão do dever de comunicar o segundo segurador, sendo válido, portanto, o novo contrato. Presume-se, todavia, a má-fé do segurado que deixar de comunicar o segurador primitivo, tanto em razão do descumprimento da expressa determinação legal como em razão da ocultação de fato que pode afetar o interesse legítimo ${ }^{368}$.

${ }^{367}$ DELGADO, José Augusto. Comentários ao novo Código Civil, p. 115. Na mesma trilha segue o pensamento de ALVIM, Pedro. O seguro no novo Código Civil, p. 120.

${ }^{368}$ Nesse sentido: TZIRULNIK, Ernesto; CAVALCANTI, Flávio de Queiroz B.; PIMENTEL, Ayrton. $O$ contrato de seguro no novo Código Civil, p. 115. 
Para outra parcela da doutrina, porém, o segurado que descumprir o dever previsto no art. 782 fica sujeito às sanções do art. $766^{369}$.

A orientação da Susep diverge de ambos os posicionamentos doutrinários. De acordo com o modelo de "Cláusula de Concorrência de Apólices" prevista na Circular n. 254/2004 da Susep $^{370}$, o segurado deve comunicar não só ao primeiro segurador, mas também ao segurador com quem pretende contratar o segundo seguro, perdendo o direito à garantia de todos os seguros, se assim não o fizer.

Uma vez cumprido o requisito de comunicação prévia, os contratos operam normalmente se a soma das importâncias seguradas for igual ou inferior ao valor do interesse segurável (valor máximo de indenização). Caso as somas superem o interesse, o valor de cada garantia será reduzido proporcionalmente.

Nessa linha é a previsão do Projeto n. 3.555/2004:

${ }^{369}$ Nesse sentido: TEPEDINO, Gustavo; BARBOZA, Heloisa Helena; MORAES, Maria Celina Bodin de. Código Civil interpretado: conforme a Constituição da República, v. II, p. 783.

370 “ 1 - CLÁUSULA DE CONCORRÊNCIA DE APÓLICES

1.1 - O segurado que, na vigência do contrato, pretender obter novo seguro sobre o mesmo bem e contra os mesmos riscos, deverá comunicar, previamente, por escrito, a sua intenção a todas as sociedades seguradoras envolvidas, SOB PENA DE PERDA DE DIREITO.

1.2 - O valor total da indenização relativa a qualquer sinistro não poderá exceder, em nenhuma circunstância, o valor do bem.

1.3 - Para fins de cálculo da distribuição de responsabilidade relativa a um sinistro, serão consideradas as seguintes parcelas:

a) as despesas de salvamento COMPROVADAMENTE efetuadas pelo Segurado durante e/ou após a ocorrência do sinistro;

b) o valor referente aos danos materiais COMPROVADAMENTE causados pelo segurado e/ou por terceiros na tentativa de minorar o dano ou salvar a coisa;

c) os prejuízos sofridos pelo bem segurado.

1.4 - Na ocorrência de sinistro, a distribuição das responsabilidades entre as apólices existentes obedecerá às seguintes condições:

a) se a soma dos Limites Máximos de Garantia das apólices for igual ou inferior à soma dos valores estipulados no subitem 1.3 desta cláusula, cada sociedade seguradora envolvida participará como se o respectivo contrato fosse o único vigente.

b) se a soma dos Limites Máximos de Garantia das apólices exceder a soma dos valores estipulados no subitem 1.3 desta cláusula, cada sociedade seguradora envolvida participará com percentual desta última soma igual à proporção entre o respectivo Limite Máximo de Garantia e a primeira soma.

1.4.1 - Os Limites Máximos de Garantia devem ser obtidos após a dedução de eventuais franquias e/ou participações obrigatórias.

1.4.2 - A sub-rogação relativa a salvados operar-se-á na mesma proporção segundo a qual cada sociedade seguradora participou do pagamento da indenização.

1.5 - Salvo disposição em contrário, a sociedade seguradora que participar com a maior parte da indenização ficará encarregada de negociar os salvados e repassar a quota-parte relativa ao produto desta negociação às demais participantes."

Incluir, ainda, quando couber, a seguinte disposição:

"1.6 - Esta cláusula não se aplica às coberturas que garantam morte e/ou invalidez." 
“Art. 34 - Ocorre seguro cumulativo quando a distribuição entre várias seguradoras for feita pelo segurado ou estipulante por força de contratações separadas.

$\S 1^{\underline{o}}$ - Nos seguros cumulativos de dano, o segurado deverá comunicar a cada uma das seguradoras sobre a existência dos contratos com as demais.

$\S 2^{\underline{0}}$ - Será reduzida proporcionalmente a importância segurada de cada contrato celebrado quando a soma das importâncias seguradas nos seguros cumulativos de dano superar o valor do interesse".

Inova, porém, o Projeto ao prever, no $\S 3^{\underline{0}}$ do mesmo artigo, que a redução proporcional não levará em conta os contratos celebrados com as seguradoras que se encontrarem insolventes.

Sobre o Projeto de Lei de Seguros, comenta Moitinho de Almeida que a disposição adota o sistema da proporcionalidade, ao passo que as leis europeias mais modernas consideram todas as seguradoras responsáveis, dentro dos limites da respectiva obrigação pela indenização devida ao segurado. A divergência diz respeito a se o pagamento é feito obedecendo a uma ordem de datas - iniciando pelo seguro mais antigo - ou na proporção das quantias seguras. $\mathrm{O}$ autor anota que a divergência de regimes tem causado conflitos de direito internacional, nos casos em que as leis de cada um dos seguros contratados estabelecem sistemas diversos de pagamento e responsabilidade ${ }^{371}$.

Conforme Halperin, na Lei argentina, quando a pluralidade de seguros acarreta o sobresseguro, a lei culmina de nulidade os contratos posteriores (art. 500 do Código Comercial argentino) que excedam o valor do interesse. A Lei argentina, no entanto, adotou o sistema italiano segundo o qual todos os seguradores são considerados responsáveis proporcionalmente ao risco assumido. A Lei alemã e a francesa estabelecem com clareza a solidariedade entre os seguradores nesse caso.

Reitera-se, assim, que a lei impõe ao segurado o dever de informar os seguros anteriores vigentes, razão pela qual, em rigor, as apólices contêm cláusula nesse sentido.

${ }^{371}$ ALmEID A, J. C. Moitinho de. Contrato de seguro: estudos, p. 246-247. 


\section{CAPÍTULO 5}

\section{O INTERESSE SEGURÁVEL NO SEGURO DE RESPONSABILIDADE CIVIL}

\subsection{O tratamento da matéria no Código Civil de 1916}

O seguro de responsabilidade civil é definido no art. 787 do Código Civil como aquele pelo qual o segurador garante o pagamento de perdas e danos devidos pelo segurado a terceiro.

O Código Civil de 1916 não trazia uma disposição específica sobre o seguro de responsabilidade civil, possivelmente em função de o seguro "de ato ilícito" não ser inicialmente aceitável pela doutrina, que considerava o ato culposo inassegurável ${ }^{372}$. Com o próprio desenvolvimento da responsabilidade civil, resultado do incremento do risco, o seguro de responsabilidade assumiu enorme importância e, hodiernamente, várias modalidades têm a sua contratação imposta pelo legislador, como política social, considerando o risco de determinadas atividades ${ }^{373}$.

O seguro de responsabilidade civil foi, assim, inicialmente sistematizado a partir das disposições gerais acerca do contrato de seguro ${ }^{374}$, lembrando que o Código antigo não trazia uma disciplina específica para os seguros de danos e seguros de pessoas, e sim

\footnotetext{
${ }^{372}$ Nos dias atuais, apenas o ato doloso é considerado inassegurável, conforme explica Comparato: "O ato intencional do segurado, do beneficiário, ou de seus representantes, é o único essencialmente inassegurável por excluir a álea e, portanto, o risco" (COMPARATO, Fabio Konder. Substitutivo ao capítulo referente ao contrato de seguro no anteprojeto de Código Civil. Revista de Direito Mercantil, n. 5, p. 147).

${ }^{373}$ Sobre o tema, explica Pontes de Miranda que "[...] repugnava aos juristas e aos legisladores a concepção de seguros contra sinistros causados por culpa do contratante. Sustentava-se a insegurabilidade em caso de danos provenientes de atos culposos do favorecido. Primeiro surgiu contra o óbice geral e indiscriminativo o argumento de haver casos de responsabilidade objetiva e de responsabilidade apenas por presunção de culpa. Depois, teve-se de atender a que o seguro de responsabilidade de certo modo protege as vítimas, pela destinação da indenidade. Finalmente, a intensificação do tráfico e das máquinas contemporâneas de transporte, terrestres e aéreos, veio pôr ao vivo a necessidade de se segurar a responsabilidade dos dirigentes e donos de veículos. Porém não só. Algumas profissões e atividades comerciais e industriais tornaram urgente a prática dos seguros de responsabilidade (hotéis, hospedarias, teatros, cinemas, fábricas de produtos perigosos, transportes de pessoas, guarda-móveis, criadores de cavalos e outros animais, acidentes do trabalho) (PONTES DE MIRANDA, Francisco Cavalcante. Tratado de Direito Privado, t. XLVI, § 4.970, p. 47).

374 Nesse sentido: MELO, Gustavo de Medeiros. A ação direta do terceiro prejudicado no seguro de responsabilidade civil - uma análise do sistema jurídico brasileiro. Revista Brasileira de Direito do Seguro e da Responsabilidade Civil, São Paulo: MP Editora, 2009. p. 136.
} 
disposições gerais referentes ao seguro de coisa e uma seção dedicada ao seguro de vida. Por essa razão, o conceito era pouco explorado pelos civilistas brasileiros.

Pontes de Miranda, sempre na vanguarda, já tratava separadamente do seguro de responsabilidade civil, assim o definindo:

\begin{abstract}
"Seguro de responsabilidade - dito frequentemente seguro de responsabilidade civil, para distinguir da penal ${ }^{375}$ - é seguro contra o risco de ser responsável a ressarcir danos. O segurador vincula-se a prestar ao segurado aquilo que esse tenha que despender a terceiro (capital, interesses, despesas). A responsabilidade, que se segura, é qualquer responsabilidade em que não haja dolo do segurado, perante terceiro, por dano à pessoa desse, ou a bens, inclusive animal, que pertença ao terceiro",376.
\end{abstract}

E esclarece o autor em comento: "O conteúdo específico do seguro de responsabilidade consiste em se indenizar o que o patrimônio perca, por ter de responder o seu titular ${ }^{377}$.

Nesse contexto, o objeto do interesse no seguro de responsabilidade civil é o patrimônio do segurado, pois o objetivo do seguro de responsabilidade civil é evitar a perda de patrimônio em razão da indenização devida por seu titular a terceiros. O risco é justamente a responsabilidade civil do segurado, seja ela aquiliana ou contratual $^{378}$. Reconhecendo o seguro de responsabilidade civil como um seguro de patrimônio, Alguns

\footnotetext{
${ }^{375}$ A distinção entre seguro de responsabilidade civil e penal é importante. Apenas a responsabilidade civil é passível de ser segurada, incluindo a responsabilidade objetiva que independe da prova de culpa. A responsabilidade penal, porém, não é um risco segurável, mesmo que a pena constitua um pagamento em dinheiro, porque não é admissível a transferência da pena que tenha caráter personalíssimo. Nesse sentido: MORANDI, Juan Carlos Felix. Estudios de derecho de seguros, p. 399. O autor adverte, porém, que "no debe confundirse la responsabilidad penal con el resarcimiento que en función del art. 29, Cód. Penal, se puede imponer al asegurado, por haber solicitado la víctima, en el proceso penal, la fijación de la reparación de los daños y perjuicios (ibidem, p. 399).

${ }^{376}$ PONTES DE MIRANDA, Francisco Cavalcante. Tratado de Direito Privado, t. XLVI, § 4.971, p. 50.

${ }^{377}$ Ibidem, $\$ 4.970$, p. 48.

${ }^{378}$ Mello Franco leciona que "O fato gerador do direito à indenização pelo segurado é o fato danoso do segurado, independentemente da indagação de ilicitude, dolo ou culpa, e a indenização abrange as consequências tanto morais, quanto materiais de quaisquer atos danosos, praticados pelo segurado" (FRANCO, Vera Helena de Mello. Contratos no Direito Privado: direito civil e empresarial, p. 314)). Convém esclarecer, porém que, conforme previsão expressa do art. 762 do Código Civil, o ato doloso do próprio segurado exclui a cobertura securitária, mesmo no seguro de danos indiretos. Essa restrição legal não se aplica, se o fato gerador da responsabilidade for o dolo de terceiro (responsabilidade por fato de outrem), salvo se expressamente prevista como risco excluído do contrato de seguro. Nesse sentido: PONTES DE MIRANDA, Francisco Cavalcante, op. cit., § 4.972, p. 54.
} 
tratadistas denominavam o seguro de responsabilidade civil como "seguro de patrimônio" ${ }^{379}$ por reconhecê-lo como tal.

\subsection{O regime jurídico instituído pelo novo Código Civil}

$\mathrm{Na}$ disciplina do Código Civil atual, foram criados dois regimes jurídicos diferentes: um para o seguro facultativo de responsabilidade civil, regido pelo já referido art. 787, e outro para o seguro de responsabilidade civil de contratação obrigatória, regido pelo art. 788.

\subsubsection{Seguro obrigatório de responsabilidade civil}

O seguro de responsabilidade civil obrigatório, como o próprio nome diz, tem a contratação imposta pelo Estado, em contraposição ao segurado facultativo, que é livremente estipulado pelo segurado. O seguro obrigatório tem caráter social e visa proteger a vítima de determinadas atividades ${ }^{380}$.

O art. 20 do Decreto-lei n. 73/1966 ${ }^{381}$ estabelece alguns dos seguros de contratação obrigatória no Brasil. Nem todos, porém, são de responsabilidade civil, enquadrando-se

\footnotetext{
${ }^{379}$ É o caso de FANELLI, Giuseppe. Le assicurazioni. Milano: Giuffrè, 1973. t. 1.

${ }^{380}$ Sobre o tema, explica Mello Franco: "O interesse tutelado, no seguro obrigatório, é a incolumidade dos atos danosos para a terceira vítima que é a beneficiária indireta do contrato. Com este teor, o seguro aproxima-se da estipulação em favor de terceiros." (FRANCO, Vera Helena de Mello. Contratos no Direito Privado: direito civil e empresarial, p. 315).

381 “Art. 20. Sem prejuízo do disposto em leis especiais, são obrigatórios os seguros de:

a) Danos pessoais a passageiros de aeronaves comerciais;

b) responsabilidade civil do proprietário de aeronaves e do transportador aéreo; [01]

c) Responsabilidade civil do construtor de imóveis em zonas urbanas por danos a pessoas ou coisas;

d) Bens dados em garantia de empréstimos ou financiamentos de instituições financeiras públicas;

e) Revogada [02];

f) Garantia do pagamento a cargo de mutuário da construção civil, inclusive obrigação imobiliária;

g) Edifícios divididos em unidades autônomas;

h) Incêndio e transporte de bens pertencentes a pessoas jurídicas, situados no País ou nele transportados;

i) Crédito rural;

j) Crédito à exportação, quando julgado conveniente pelo CNSP, ouvido o Conselho Nacional do Comércio Exterior;
} 
nessa categoria apenas os previstos nas alíneas "b", "c" e "m", respectivamente, para os proprietários de aeronaves e transportadores aéreos; para os construtores de imóveis em zonas urbanas; e para os transportadores terrestres, marítimos, fluviais e lacustres, nos casos de danos causados à carga transportada.

Note-se que o seguro de danos pessoais causados por veículos automotores de vias terrestres, previsto na alínea "l”, conhecido como Seguro DPVAT, é um seguro de danos pessoais, e não um seguro de responsabilidade civil obrigatório, como comumente referido. A confusão se deve ao fato de que, na sua redação primitiva, o inciso "b",382 do art. 20 do Decreto-lei n. 73/66 previa expressamente a contratação obrigatória de seguros de responsabilidade civil dos proprietários de veículos automotores de via terrestre, dando origem ao seguro respectivo de Responsabilidade Civil dos Proprietários de Veículos Automotores de vias terrestres, o antigo "Seguro RECOVAT". O referido inciso foi modificado pela Lei n. 6.194/74, que inseriu a alínea "l", instituindo o seguro DPVAT, cujas coberturas são morte, invalidez permanente e reembolso de despesas médicas e hospitalares ${ }^{383}$.

A norma do art. 788 é clara ao estipular que, "nos seguros de responsabilidade legalmente obrigatórios, a indenização por sinistro será paga pelo segurado diretamente ao terceiro prejudicado".

Comparato, autor do anteprojeto, esclarece que foram estabelecidos, propositadamente, regimes jurídicos diversos para o seguro de responsabilidade civil facultativo e o obrigatório. Neste último, "a causa do contrato deixa de ser o interesse individual da proteção do patrimônio do segurado, e passa a ser o interesse social da garantia de indenização aos terceiros vítimas" ${ }^{384}$.

\footnotetext{
1) danos pessoais causados por veículos automotores de vias terrestres e por embarcações, ou por sua carga, a pessoas transportadas ou não;

m) responsabilidade civil dos transportadores terrestres, marítimos, fluviais e lacustres, por danos à carga transportada."

382 “[...] b) responsabilidade civil dos proprietários de veículos automotores de vias terrestre, fluvial, lacustre e marítima, de aeronaves e do transportador em geral".

${ }^{383}$ O pagamento da indenização prevista no seguro DPVAT independe de apuração de responsabilidade e é devido a todas as vítimas de acidentes automobilísticos, pela simples verificação do dano, inclusive ao motorista e passageiros do veículo segurado (Decreto-lei n. 6.194/74 - "Art. 5º O pagamento de indenização será efetuado mediante simples prova do acidente e do dano decorrente, independentemente da existência de culpa, haja ou não resseguro, abolida qualquer franquia de responsabilidade do segurado.".) Ademais, a legislação prevê o pagamento da indenização mesmo na ausência de pagamento do "prêmio" - que, conforme precedentes jurisprudenciais, tem no seguro DPVAT natureza de contrituição parafiscal - RESP 68146/SP), de forma que não se aplica o parágrafo único do art. 788 do Código Civil.

${ }^{384}$ COMPARATO, Fabio Konder. Substitutivo ao capítulo referente ao contrato de seguro no anteprojeto de Código Civil. Revista de Direito Mercantil, n. 5, p. 149.
} 
Nos seguros obrigatórios de responsabilidade civil, o pagamento da indenização deve ser feito obrigatoriamente à vítima, sob pena de pagar mal o segurador que o fizer ao segurado $^{385}$. Trata-se, tipicamente, de um seguro contratado no interesse de terceiros ${ }^{386}$. O titular do interesse segurado, portanto, é a própria vítima de danos causados por acidente de trânsito, indeterminado no momento da contratação, que passa a ser determinado após a ocorrência do sinistro e a caracterização dos danos ${ }^{387}$.

\subsection{0 desenvolvimento da responsabilidade civil e os reflexos no interesse segurável no Código Civil de 2002}

O conceito do seguro de responsabilidade não passou incólume à transformação que o instituto sofreu em decorrência do próprio desenvolvimento da sociedade. Tzirulnik, em denso artigo sobre o tema, publicado antes mesmo do advento do novo Código Civil, já definia o seguro de responsabilidade civil como "um seguro de dano que visa a prevenir o risco de diminuição do patrimônio do segurado - não a recompô-lo - e simultaneamente a potencializar a recomposição do patrimônio do lesado, por dano causado durante a vigência material do contrato" 388 .

A redação dada ao art. 787, segundo o qual, "no seguro de responsabilidade civil, o segurador garante o pagamento de perdas e danos devidos pelo segurado a terceiro", reforçou, para grande parte da doutrina, a noção de que, mesmo no seguro facultativo, o objeto do interesse do segurado não se limitava ao seu próprio patrimônio. Afinal, o artigo prevê expressamente que a garantia securitária atua no interesse da vítima prejudicada pelo ato danoso do segurado.

\footnotetext{
${ }^{385}$ Comparato destaca: "Tal como prevista no art. XXVII, ela se funda na obrigação do segurador de pagar a indenização por sinistro unicamente ao terceiro vítima, de sorte que o pagamento a qualquer outra pessoa, inclusive o segurado, não tem efeito liberatório" (COMPARATO, Fabio Konder. Substitutivo ao capítulo referente ao contrato de seguro no anteprojeto de Código Civil. Revista de Direito Mercantil, n. 5, p. 149).

${ }^{386}$ Cf. TEPEDINO, Gustavo; BARBOSA, Heloisa Helena; MORAES, Maria Celina Bodin. Código Civil interpretado conforme a Constituição da República, v. II, p. 597.

${ }^{387}$ Nesse sentido: TZIRULNIK, Ernesto; CAVALCANTI, Flávio de Queiroz B.; PIMENTEL, Ayrton. $O$ contrato de seguro novo Código Civil, p. 139-140; FRANCO, Vera Helena Mello. Contratos no Direito Privado: direito civil e empresarial, p. 315; e SANTOS, Ricardo Bechara. Direito do seguro no novo Código Civil e legislação própria, p. 319.

388 TZIRULNIK, Ernesto. Em torno do interesse segurável e da responsabilidade civil. In: ESCOLA PAULISTA DE MAGISTRATURA/EPM; INSTITUTO BRASILEIRO DE DIREITO DO SEGURO IBDS. Seguros: uma questão atual, p. 378.
} 
A divergência doutrinária se coloca para aqueles que seguem defendendo o interesse exclusivo do segurado relativamente à proteção de seu patrimônio; aqueles que enxergam dois interesses: do segurado e da vítima; e aqueles que entendem que o interesse é exclusivo da vítima. A discussão não é nova, tampouco se limita ao Direito brasileiro.

Para Tzirulnik, Cavalcanti e Pimentel, há uma simultaneidade de interesses: do segurado, responsável pelo dano e interessado na não oneração de seu patrimônio; e da vítima, que sofre as consequências do dano causado pelo segurado e busca a sua reparação ${ }^{389}$. Extrai-se, da norma consubstanciada no indigitado art. 787, que "a seguradora garante que fará o pagamento do que, a título de perdas e danos, for devido pelo segurado a terceiro" ${ }^{, 390}$, ou seja, a proteção ao patrimônio do segurado é no sentido de pagar diretamente à vítima, evitando o desembolso para posterior reembolso. Conforme explicam os autores, o artigo transmite duas ideias, que se complementam: "a de que a prestação de garantia é devida ao segurado e a de que sua extinção se dá mediante o pagamento ao terceiro, pagamento que libera a seguradora junto ao segurado e ao terceiro e aquele perante este" ${ }^{, 391}$.

Delgado, indo mais além, entende que a garantia prevista no art. 787 do Código Civil de 2002 é do terceiro "vítima de danos produzidos por outrem, em razão do sinistro cujo risco está acobertado por seguro". Conclui que "a lei alcança, portanto, uma relação jurídica que nasce do seguro celebrado e do dano produzido e que tem como partes o segurador e a vítima que, originalmente, não integrou a formação do contrato" ${ }^{\text {392 }}$. Alvim e Tepedino $^{393}$ partilham da mesma orientação. Segundo Alvim, a interpretação do caput do art. 757 somente pode ser no sentido de que o seguro garante o terceiro e não o segurado, pois, "Se outro fosse o pensamento do legislador, outra também teria sido a redação do dispositivo para não suscitar dúvidas, isto é, o segurador garante ao segurado o pagamento das perdas e danos devidos a terceiro" 394 .

\footnotetext{
389 TZIRULNIK, Ernesto. Em torno do interesse segurado e da responsabilidade civil. In: ESCOLA PAULISTA DE MAGISTRATURA/EPM; INSTITUTO BRASILEIRO DE DIREITO DO SEGURO IBDS. Seguros: uma questão atual, p. 134.

${ }^{390}$ Ibidem, p. 138.

391 Ibidem, p. 140.

${ }^{392}$ DELGADO, José Augusto. Comentários ao novo Código Civil. Rio de Janeiro: Forense, 2004. p. 563. (Das várias espécies de contrato, do seguro, v. XI).

393 TEPEDINO, Gustavo; BARBOSA, Heloisa Helena; MORAES, Maria Celina Bodin. Código Civil interpretado conforme a Constituição da República, v. II, p. 595-596.

${ }^{394}$ ALVIM, Pedro. O seguro no novo Código Civil, p. 143.
} 
Mello Franco ${ }^{395}$ e Bechara ${ }^{396}$, por sua vez, sustentam que o objeto do interesse é o patrimônio do segurado, não o do terceiro. Também é essa a opinião de Provost, para quem o interesse do segurado não é de indenizar a vítima, e sim de proteger seu próprio patrimônio. O temor que move o segurado é de ser responsabilizado, vindo a sofrer um aumento do seu passivo patrimonial. Conclui, assim, a autora que o seguro de responsabilidade civil não garante o interesse da vítima, mas sim o interesse do segurado de não diminuição de patrimônio em razão de sua eventual responsabilização por um dano causado à vítima ${ }^{397}$.

Em que pese o inquestionável interesse da vítima no recebimento da indenização, não se trata de interesse segurável propriamente dito, entendido como aquele existente entre o sujeito e o bem, ameaçado por um risco. Entende, neste estudo, o objeto do interesse no seguro de responsabilidade civil continua a ser o patrimônio do segurado. $\mathrm{O}$ interesse da vítima, destinatária da indenização a ser paga pela seguradora, nos limites contratados, não se identifica com esse do segurado, mas sim com o interesse típico do beneficiário. A diferença, porém, é que a indenização devida à vítima se sujeita, de um lado, à configuração da responsabilidade do segurado e, de outro, aos próprios limites de cobertura previstos na apólice, seja no que se refere ao limite segurado, aos riscos cobertos e excluídos - por exemplo: danos materiais, corporais e/ou morais -, bem como ao prejuízo efetivamente sofrido por ela. Tais limitações decorrem do fato de que a responsabilidade da seguradora continua a ser contratual, não se confundindo com a responsabilidade do causador do dano. A seguradora deve, sim, pagar à vítima, mas nos estritos limites do que foi contratado com o segurado ${ }^{398}$.

\footnotetext{
${ }^{395}$ FRANCO, Vera Helena Mello. Contratos no Direito Privado: direito civil e empresarial, p. 317-318.

${ }^{396}$ BECHARA, Ricardo. Direito do seguro no novo Código Civil e legislação própria, p. 316-317.

${ }^{397}$ PROVOST, Magalie. La notion d'intérèt d'assurance, p. 211.

${ }^{398}$ A questão dos limites contratuais suscita outros debates. Veja-se a recente decisão do Tribunal de Justiça de Santa Catarina que condenou a seguradora a indenizar a vítima de um acidente de trânsito causado por um segurado em estado de embriaguez, risco expressamente excluído, por entender que referida conduta não exime a seguradora perante o terceiro beneficiário. Segundo o julgado: "A conduta culposa do segurado pelo acidente de trânsito, mesmo que em estado de embriaguez, não exime a seguradora de sua obrigação perante terceiros beneficiários" (Ap. Cív. n. 008.002015, Rel. Sergio Heil, j. em 24.06.2010). O acórdão cita outro julgado do Tribunal de Justiça do Rio Grande do Sul: EMBARGOS INFRINGENTES. RESPONSABILIDADE CIVIL EM ACIDENTE DE TRÂNSITO. SEGURO DE RESPONSABILIDADE CIVIL. EMBRIAGUEZ DO SEGURADO. REPERCUSSÃO PERANTE O TERCEIRO BENEFICIÁRIO (VÍTIMA). DEVER DE INDENIZAR. No contrato de seguro de responsabilidade civil a conduta culposa do segurado, ainda que agravada pelo estado de embriaguez, não afasta o dever contratual da seguradora perante o terceiro beneficiário (vítima). EMBARGOS INFRINGENTES PROVIDOS, POR MAIORIA DE VOTOS. (Embargos Infringentes n. 70030235451, Sexto Grupo de Câmaras Cíveis, rel. Judith dos Santos Mottecy, j. em 27/11/09.)
} 
$\mathrm{O}$ art. 104 do substitutivo ao Projeto n. 3.555/2004 ${ }^{399}$, porém, prevê expressamente que o seguro de responsabilidade civil garante tanto o interesse do segurado, contra os efeitos da imputação de responsabilidade e do seu reconhecimento, como o interesse dos terceiros prejudicados à indenização. Dispõe, ainda, que ambos são credores da garantia, mas apenas a vítima é credora da indenização, tendo ação direta contra a seguradora. Ao segurado, são garantidos os gastos com a sua defesa, mediante a fixação de valor específico para esse fim.

\section{$5.4 \mathrm{O}$ interesse no resseguro}

Também no resseguro, o objeto de interesse da seguradora-ressegurada é o seu patrimônio. O resseguro assume os mesmos contornos do seguro de responsabilidade civil, diferenciando-se, no entanto, quanto ao risco. No primeiro, o risco se verifica pelo dano causado a terceiro, em decorrência da inobservância culposa de norma legal ou contratual ou de configuração de responsabilidade objetiva. No resseguro, o risco decorre do próprio cumprimento pelo ressegurador do contrato celebrado com o segurado ${ }^{400}$.

Poder-se-ia questionar se o interesse no resseguro é contrário à realização do evento - no caso, ao não pagamento da indenização -, na medida em que se trata não de uma responsabilidade por inadimplemento contratual, mas sim de responsabilidade pelo pagamento de uma indenização prevista contratualmente. Conforme esclarece Piza, é inquestionável o interesse do segurador na não realização do risco, convergindo com o próprio interesse do segurado e do ressegurador. Com a verificação do sinistro, o que era interesse passa a ser dano, de maneira que, "ao se identificar o interesse com o dano, o que se está fazendo, em verdade, é identificando uma relação entre o ressegurado e um seu

\footnotetext{
399 "Art. 104. O seguro de responsabilidade civil garante o interesse do segurado contra os efeitos da imputação de responsabilidade e do seu reconhecimento, e o interesse dos terceiros prejudicados à indenização.

Parágrafo único. O risco pode caracterizar-se pela ocorrência do fato gerador, da manifestação danosa ou da imputação de responsabilidade.

Art. 105. São credores da garantia o segurado e os prejudicados.

$\S 1^{\circ}$ Os prejudicados são os únicos credores da indenização devida pela seguradora, salvo o disposto no $\S 3^{0}$ deste artigo, e poderão exercer seu direito de ação contra esta, respeitado o limite garantido pelo contrato, com a faculdade de citar o responsável como litisconsorte."

${ }^{400}$ Nesse sentido: FERRARINI, Sergio. L'interesse nell'assicurazione, p. 81. E também FANELLI, Giuseppe. Le assicurazioni. t. I, p. 166-167.
} 
estado patrimonial que não corresponde ao interesse que se buscou preservar por meio do contrato de resseguro" ${ }^{, 401}$.

Essa natureza de seguro de patrimônio ou seguro de responsabilidade (contratual) do resseguro não se modifica pelo fato de a indenização devida pelo segurador-ressegurado ter natureza diversa daquela de um seguro de dano - por exemplo, do capital estipulado num seguro de vida. A garantia do segurador não equivale à garantia do ressegurador, a qual se refere ao risco da atividade securitária ${ }^{402}$.

O interesse ressegurável, por ser definido, assim, como "o interesse jurídicoeconômico do segurador em relação à preservação do seu patrimônio, que se prende, antes de mais nada, à satisfação dos débitos decorrentes do exercício da atividade securitária"403.

\subsection{Interesse e valor segurado no seguro de responsabilidade civil}

O interesse segurável é, conforme assinalado, a medida do valor segurável, entendido como o prejuízo máximo a que está exposto o segurado, em função de sua relação com um bem, ameaçada por determinado risco. Em decorrência da aplicação do princípio indenitário, quando o valor segurado não corresponde ao valor segurável, a legislação prevê determinadas consequências, dependendo da caracterização do sobresseguro ou do infrasseguro. O mesmo princípio determina que, a despeito do valor segurado, a indenização a ser paga ao segurado não deve superar o valor do prejuízo sofrido.

Em face da natureza particular do interesse no seguro de responsabilidade civil, nem sempre é possível estabelecer o valor segurável. Já foi dito que, no seguro de responsabilidade civil, o interesse recai sobre o patrimônio como um todo do segurado, contra o risco de responsabilidade em relação a um terceiro. O interesse sobre o patrimônio depende, portanto, da exposição do segurado ao risco de alteração negativa da situação patrimonial, por dívidas a seu cargo decorrentes de determinadas circunstâncias geradoras

\footnotetext{
${ }^{401}$ PIZA, Paulo Luiz de Toledo. Contrato de resseguro: tipologia, formação e direito internacional, p. 207.

${ }^{402}$ Nesse sentido: ASCARELLI, Tullio. O conceito unitário do contrato de seguro In: Problemas das sociedades anônimas e Direito Comparado, p. 225.

${ }^{403}$ PIZA, Paulo Luiz de Toledo, op. cit., p. 208.
} 
de responsabilidade. Trata-se, pois, de medir a exposição ao risco de aumento do passivo patrimonial do segurado.

Como ressalta Fanelli ${ }^{404}$, é preciso distinguir os casos em que é possível um cálculo preventivo da exposição ao risco do segurado - por exemplo, a guarda de um bem, a responsabilidade contratualmente limitada a valor determinado ou a certas espécies de danos -, daqueles casos em que a referida exposição é ilimitada. Na primeira hipótese, ainda que não seja possível precisar com exatidão o valor segurável, como se dá, em regra, no seguro de coisa, é possível ao menos estimar o limite de responsabilidade a que o segurado está sujeito em face do risco especificamente assumido e indicado no contrato.

Quando não há limitação da responsabilidade, não é possível delimitar o valor segurável, apenas o valor segurado, que, nesse caso, não guarda equivalência com o primeiro, significando apenas o limite de garantia do segurador. De fato, se o valor segurável é ilimitado, o mesmo não pode ocorrer com o valor segurado. Trata-se de um requisito de ordem técnica - e não jurídica -, para dimensionar e agrupar o risco assumido e, assim, calcular o prêmio respectivo ${ }^{405}$.

Diante dessa impossibilidade de se estabelecer o valor segurável, não se aplica ao seguro de responsabilidade civil a disciplina relativa ao infrasseguro, ao sobresseguro e à pluralidade de seguros.

\footnotetext{
${ }^{404}$ FANELLI, Giuseppe. Le assicurazioni, p. 236.
}

${ }^{405}$ Ibidem, p. 236. 


\section{CAPÍTULO 6}

\section{O INTERESSE SEGURÁVEL NO SEGURO DE PESSOAS}

\subsection{Natureza dos seguros de pessoas}

Conforme observado, o Código Civil de 2002 adotou o conceito unitário do contrato de seguros, que tem como elemento unificador do seguro de danos e do seguro de pessoas o interesse legítimo do segurado. Aqui, o bem objeto desse interesse de preservação é a própria pessoa humana, e os riscos são aqueles inerentes à existência do ser humano.

O seguro de pessoas mereceu uma disciplina própria na legislação, tendo em vista que, em regra, o caráter indenitário próprio dos seguros de dano não está presente nos seguros de pessoas. Comparato explica que o seguro de pessoas é de índole previdenciária, faltando-lhe o aspecto indenitário ${ }^{406}$.

O dano, no entanto, também existe no seguro de pessoas. Nas palavras de Pontes de Miranda: "Tanto é risco morrer, como o que a morte acarreta de danos, como viver após o momento que se reputa ser o início de diminuição de meios, como o de aptidão para o trabalho" ${ }^{407}$. A pessoa humana não tem um "valor de mercado"; por isso, o seguro de pessoas não assume, em princípio, uma função ressarcitória. A sua índole geral é de prevenção do dano, de antevê-lo, de previdência ${ }^{408}$.

Há seguros de pessoas, contudo, com nítido viés indenitário; por isso, para alguns autores, como Tzirulnik, Cavalcanti e Pimentel, os seguros de pessoas podem ter função indenizatória, mas não sempre ${ }^{409}$. Entende-se, assim, mais adequada a explanação de Buttaro, para quem, não se trata de negar a função indenitária nos seguros de pessoas, ou de admiti-la somente em algumas hipóteses, mas de reconhecer que, nessa modalidade, tal

\footnotetext{
${ }^{406}$ COMPARATO, Fabio Konder. Substitutivo ao capítulo referente ao contrato de seguro no anteprojeto de Código Civil, p.150.

${ }^{407}$ PONTES DE MIRANDA, Francisco Cavalcante. Tratado de Direito Privado, t. XLVI, § 4.957, p. 5-6.

${ }^{408}$ COMPARATO, Fabio Konder, op. cit., p. 150.

409 TZIRULNIK, Ernesto; CAVALCANTI, Flávio de Queiroz B.; PIMENTEL, Ayrton. O seguro de acordo como o novo Código Civil brasileiro, p. 151-152.
} 
função se apresenta de forma muito mais tênue, de natureza diversa daquela dos seguros de $\operatorname{danos}^{410}$.

\subsection{Noções essenciais sobre seguros de pessoas}

Já foi assinalado que o interesse no seguro de pessoas se reporta sempre à pessoa humana, no tocante aos riscos inerentes à existência do ser humano. Não há, portanto, alteração de objeto. As diversas modalidades de seguro de pessoas diferenciam-se, no que tange ao risco e à relação existente entre o sujeito e o bem. No que concerne ao risco, as duas principais modalidades de seguros de pessoas são os seguros de vida e os seguros de acidentes pessoais $^{411}$. Estes não são, porém, os únicos; há ainda os seguros de "diárias por incapacidade temporária”, diárias hospitalares, dentre outros subtipos.

\subsubsection{Seguro de vida}

Os riscos no seguro de vida são aqueles atinentes à duração da vida humana. Nas palavras de Tzirulnik, Cavalcanti e Pimentel, "é um seguro sobre a incerteza da vida humana" ${ }^{412}$. O risco tanto pode ser de morte, como de sobrevivência após determinada idade. Há seguros que congregam os dois tipos de risco; são os denominados seguros mistos.

O risco, no seguro de vida, é substancialmente diverso de todos os demais riscos no seguro, pois a morte da pessoa humana é certa; apenas a data de sua ocorrência é incerta; por isso, conforme assinalado, o risco é conceituado como "o acontecimento futuro e incerto, ou de data incerta, que não depende somente da vontade das partes"413.

\footnotetext{
${ }^{410}$ BUTTARO, Luca. L'interesse nell'assircurazione, p. 11.

${ }^{411} \mathrm{O}$ interesse no seguro-saúde também se reporta à integridade humana, mas é tratado como seguro de dano, já que se submete ao princípio indenitário. Por isso, a expressa exclusão do art. 802 do Código Civil de 2002. 412 TZIRULNIK, Ernesto; CAVALCANTI, Flávio de Queiroz B.; PIMENTEL, Ayrton. O contrato de seguro de acordo com o novo Código Civil brasileiro, p. 154.

${ }^{413}$ ALVIM, Pedro. O contrato de seguro, p. 215.
} 
Outra característica do risco, nessa modalidade, diz respeito à sua permanente agravação, uma vez que é inerente à existência humana a maior probabilidade de morte, à medida que a idade avança ${ }^{414}$.

No seguro de sobrevivência, o sinistro caracteriza-se pelo fato de o segurado continuar vivo após determinada idade. O capital tanto pode ser pago em verba única como pode ser uma renda vitalícia, assemelhando-se a uma previdência privada. Essa modalidade de seguro, porém, raramente é contratada desacompanhada do risco de morte, sendo mais recorrente sua inclusão no seguro misto.

\subsubsection{Seguro de acidentes pessoais}

O desenvolvimento da sociedade e o incremento do risco impactaram não só no seguro de responsabilidade civil, mas também no seguro de acidentes pessoais. A morte ou invalidez prematura do segurado, causada por um fator externo e não pela velhice ou por doenças, configura um risco próprio, diferente das chamadas "causas naturais", e um dano ainda mais gravoso para o segurado e para os dependentes deste. Em razão do reconhecimento da importância dessa proteção, o seguro de acidentes do trabalho tornou-se obrigatório e é hoje operado pelo próprio Estado.

O risco no seguro de acidentes pessoais é a lesão corporal por um acidente, cujo resultado provoque a invalidez ou a morte do segurado ${ }^{415}$; por isso, diz-se também seguro de infortúnio ${ }^{416}$. Há, também aqui, o risco de morte, mas por causas acidentais: ela decorre dos danos sofridos em razão de um acidente. Diverso do risco de morte no seguro de vida em que a morte por qualquer causa é certa -, a morte por acidente é incerta, não apenas com relação à data, mas também à sua ocorrência. A abrangência de cobertura do seguro de acidentes pessoais para o risco de morte é, portanto, menor, ou seja, mais limitada do que no seguro de $v^{4} a^{417}$. A exigência do acidente como deflagrador da cobertura securitária, entendido como o evento exclusivo, súbito, violento, involuntário e externo,

\footnotetext{
${ }^{414}$ Nesse sentido: TZIRULNIK, Ernesto; CAVALCANTI, Flávio de Queiroz B.; PIMENTEL, Ayrton. $O$ contrato de seguro de acordo com o novo Código Civil brasileiro, p. 155.

415 Ibidem, p. 158.

${ }^{416}$ PONTES DE MIRANDA. Francisco Cavalcante. Tratado de Direito Privado, t. XLVI, § 4.966, p. 37-38.

${ }^{417}$ SANTOS, Ricardo Bechara. Direito do seguro no novo Código Civil e legislação própria, p. 333.
} 
que por si só e independentemente de qualquer outro fator cause dano à integridade física ou psíquica do segurado - incluindo a morte -, levou parte da doutrina a classificar essa modalidade de seguro de pessoas como seguro de dano. É o caso de Fanelli, que se refere exclusivamente ao seguro de vida como seguro de pessoas. $\mathrm{O}$ autor denomina o seguro de acidentes pessoais como seguro contra os danos à pessoa, configurando uma terceira modalidade de seguro de dano, ao lado do seguro de coisa e do seguro de responsabilidade civil $^{418}$.

No Brasil, o próprio Decreto n. 61.589/67, que determina a classificação operacional dos seguros, incluiu o seguro de acidentes pessoais entre os chamados "ramos elementares" (conforme art. $7^{\circ}$, inc. I) ${ }^{419}$, em oposição ao seguro de vida e seguro-saúde. Trata-se de reflexo do vetusto Código Civil, que trazia uma seção específica apenas para o seguro de vida, definido nos seguintes termos pelo art. 1.471:

\begin{abstract}
"O seguro de vida tem por objeto garantir mediante o prêmio anual que se ajustar, o pagamento de certa soma a determinada ou determinadas pessoas, por morte do segurado, podendo estipular-se igualmente o pagamento de soma ao próprio segurado, ou terceiro, se aquele sobreviver ao prazo do seu contrato".
\end{abstract}

A divergência doutrinária e legislativa está ligada à dificuldade de se aceitar o "dano" na morte natural, cogitando-se de sua existência apenas no seguro de acidentes pessoais. Pontes de Miranda ${ }^{420}$ explica que "A função de indenizar, que ele [seguro de acidentes pessoais] tem, é mais próxima da função indenizatória do seguro de danos. [Porém] A atinência à pessoa põe-se no mesmo plano que o seguro de vida"421. A questão está superada no direito brasileiro, conforme assinalado, diante da teoria do interesse legítimo

\footnotetext{
${ }^{418}$ FANELLI, Giuseppe. Le assicurazioni, p. 162.

419 "Art $7^{\mathbf{o}}$ - Para os efeitos do artigo anterior, as operações das sociedades seguradores obedecerão à seguinte classificação:

I - Seguros dos Ramos Elementares - os que visem a garantir perdas e danos, ou responsabilidades provenientes de riscos de fogo, transporte, acidentes pessoais e outros eventos que possam ocorrer afetando pessoas, coisas e bens, responsabilidades, obrigações, garantias e direitos.

II - Seguros de Vida - os que, com base na duração da vida humana, visem a garantir, a segurados ou terceiros, o pagamento, dentro de determinado prazo e condições, de quantia certa, renda ou outro benefício. III - Seguro Saúde.”

${ }^{420}$ PONTES DE MIRANDA, Francisco Cavalcante. Tratado de Direito Privado, t. XLVI, § 4.966, p. 38.

${ }^{421}$ Ibidem, loc. cit.
} 
adotada pelo Código Civil. Conforme Buttaro, apesar do caráter indenitário de alguns seguros, sempre que o interesse se reportar à pessoa humana, o seguro é de pessoas ${ }^{422}$.

Apesar das diferenças entre os seguros de vida e de acidentes pessoais, ambos podem ser contratados numa única apólice, que especificará os diferentes riscos e coberturas.

\subsubsection{Seguros individuais e coletivos}

No tocante à forma de contratação, os seguros de pessoas podem ser individuais ou coletivos.

O seguro individual, em rigor, é contratado pelo próprio segurado com a seguradora, que expedirá uma apólice em seu nome. As partes envolvidas são, assim, unicamente segurado e seguradora. Caso o seguro seja contratado sobre a vida ou por conta de outrem, a contratação envolverá mais uma pessoa (o contratante), mas o seguro permanecerá com a característica de individual, já que há uma única apólice ${ }^{423}$.

No seguro coletivo ou seguro em grupo, uma pessoa física ou jurídica contrata em proveito de determinado grupo que a ela se vincule. Trata-se da possibilidade prevista no art. 801 do Código Civil de $2002^{424}$. Aqui, a apólice, chamada de apólice-mestra, engloba todos os segurados que integram o grupo. Cada segurado recebe um certificado individual do seguro, como prova de sua inclusão no grupo segurado. Nesse caso, a contratação envolverá não só os segurados e a seguradora, mas também a figura do estipulante ${ }^{425}$, que representa o grupo segurado perante a seguradora ${ }^{426}$.

O seguro coletivo não se confunde com o seguro sobre a vida de terceiro, apesar de em ambos os casos existir um terceiro sujeito, além do segurado e da seguradora. No primeiro caso, o estipulante contrata em seu próprio nome, porém em benefício do grupo;

\footnotetext{
${ }^{422}$ BUTTARO, Luca. L'interesse nell'assicurazione, p. 242.

${ }^{423}$ Cf. TZIRULNIK, Ernesto; CAVALCANTI, Flávio de Queiroz B.; PIMENTEL, Ayrton. O contrato de seguro no novo Código Civil brasileiro, p. 155.

${ }^{424}$ Art. 801, caput: "O seguro de pessoas pode ser estipulado por pessoa natural ou jurídica em proveito do grupo que a ela, de qualquer modo, se vincule".

${ }^{425}$ Conforme art. 801, "§ $1^{\circ}$. O estipulante não representa o segurador perante o grupo segurado, e é o único responsável, para com o segurador, pelo cumprimento de todas as obrigações contratuais.”.

${ }^{426}$ Cf. TZIRULNIK, Ernesto; CAVALCANTI, Flávio de Queiroz B.; PIMENTEL, Ayrton, op. cit., p. 155.
} 
e, no segundo, o contratante celebra o seguro no próprio nome e em benefício próprio ${ }^{427}$. O segurado, nesse último caso, é apenas quem se sujeita ao risco, mas não participa da contratação, tampouco designa beneficiário. Pontes de Miranda ${ }^{428}$ esclarece: "O terceiro, é o portador do risco, e não o titular do interesse". Não se deve confundir, pois, tal contrato com aquele celebrado por conta de terceiro, no qual o interesse segurado é do terceiro.

\subsection{Interesse e fixação do valor segurado}

O art. 789 do Código Civil de 2002 inaugura a seção relativa ao seguro de pessoa, estabelecendo, de plano, que "o capital segurado é livremente estipulado pelo proponente, que pode contratar mais de um seguro sobre o mesmo interesse, com o mesmo ou diversos seguradores".

Ao contrário do seguro de dano, o novo Código prevê claramente a liberdade para a fixação do capital segurado, diante da inaplicabilidade do princípio indenitário. Não se exige, pois, a correspondência entre o valor do interesse segurável e o valor efetivamente garantido prevista no art. 778, muito menos a limitação da indenização aos prejuízos, como determina o art. 781; portanto, não se aplicam às normas relativas a sobresseguro (art. 781) ou infrasseguro (art. 783$)^{429}$.

Pela mesma razão, o art. 789 admite, expressamente, a possibilidade de mais de um seguro sobre o mesmo interesse e contra os mesmos riscos, em oposição à vedação imposta pelo art. 782 aos seguros de dano. Referida disposição se aplica inclusive ao seguro de acidentes, considerado por parte da doutrina como um contrato de ressarcimento, conforme assinalado $^{430}$.

Atento à questão da inaplicabilidade do princípio indenitário, o legislador cuidou de não utilizar o termo indenização ao se referir à prestação devida pelo segurador na

\footnotetext{
${ }^{427}$ TZIRULNIK, Ernesto; CAVALCANTI, Flávio de Queiroz B.; PIMENTEL, Ayrton. O contrato de seguro no novo Código Civil brasileiro, p. 164.

${ }^{428}$ PONTES DE MIRANDA, Francisco Cavalcante. Tratado de Direito Privado, t. XLVI, § 4.966, p. 22.

${ }^{429}$ HALPERIN, Isaac. El contrato de seguro, p. 450.

${ }^{430}$ Ibidem, p. 450.
} 
ocorrência do sinistro, preferindo o vocábulo capital (capital segurado, capital garantido, capital estipulado), empregado tanto para o valor contratado como para o valor devido ${ }^{431}$.

Tendo em vista a irreparabilidade da perda da vida humana, não é possível delimitar o interesse segurável; por isso, não há de fato limite para o capital, tampouco para a quantidade de seguros. Uma vez estipulado o capital segurado, o seu pagamento independe do prejuízo efetivamente sofrido; por isso, diz-se que os seguros de pessoas constituem seguros de soma ${ }^{432}$.

A exceção é o seguro-saúde, no qual o interesse também se reporta à integridade humana, mas é seguro de dano, já que visa indenizar o segurado, seja na forma de pagamento direto aos prestadores de serviços de saúde, seja na forma de reembolso dos valores que tiver de despender no tratamento médico e/ou odontológico, ou, ainda, hospitalar. Por isso, a expressa exclusão do art. 802 do Código Civil de $2002^{433}$.

Mas, além da exclusão legal referida, em que o caráter indenitário é explícito, não são raras as vezes em que, mesmo se reportando à pessoa, o seguro visa reparar um possível prejuízo e tem função indenizatória, ainda que diferente daquela do seguro de dano.

É o caso, por exemplo, do seguro por diárias de incapacidade. Esse seguro visa pagar uma verba fixa mensal ao segurado que sofrer uma invalidez temporária por acidente ou doença que o obrigue a se ausentar do trabalho por determinado período. Nessa hipótese, caso fosse aplicada a regra do princípio indenitário, o valor da diária remeteria ao lucro cessante, devendo ser calculado de acordo com determinados critérios, como a média auferida pelo segurado no período anterior. No caso de se tratar de seguro de pessoas, no entanto, não há limitação para o valor da verba segurada, possibilitando, pela aplicação cega do art. 789, que a diária fixada seja superior à renda normalmente auferida pelo segurado, o que tornaria o sinistro vantajoso, já que o segurado recebe valor maior na inatitividade.

Mas, conforme ressalta Tzirulnik, Cavalcanti e Pimentel, a liberdade estabelecida pelo art. 789 não é ilimitada, devendo ser compatível com os princípios da boa-fé objetiva

\footnotetext{
${ }^{431}$ TZIRULNIK, Ernesto; CAVALCANTI, Flávio de Queiroz B.; PIMENTEL, Ayrton. O contrato de seguro no novo Código Civil brasileiro, p. 152.

432 Ibidem, p. 152-153.

${ }^{433}$ Não se compreende nas disposições desta Seção a garantia do reembolso de despesas hospitalares ou de tratamento médico, nem o custeio das despesas de luto e de funeral do segurado.
} 
e da função social ${ }^{434}$; ademais, entende-se que a exagerada desproporção de valores em tais casos viola o princípio expresso pela exigência do interesse legítimo, ou seja, de que o seguro não pode se converter em uma aposta, trazendo lucro ao segurado.

Os princípios apontados devem, porém, orientar a conduta de ambas as partes. Como a soma segurada, nesse caso, é fixada por estimativa, não estando adstrita ao eventual prejuízo em caso de sinistro, o momento da contratação assume relevância especial nos seguros de pessoas, não sendo por outra razão que muitas legislações exigem o interesse segurável apenas no momento da celebração do contrato ${ }^{435}$. Cabe, assim, à seguradora cuidar para que o questionário apresentado ao segurado seja claro, possibilitando respostas objetivas, para que possa analisar corretamente o risco e os valores $\operatorname{propostos}^{436}$.

\subsection{Figurantes no seguro de pessoas e interesse segurável}

Conforme observado, muitas vezes, no seguro de pessoas, existem outros figurantes além do segurado e da seguradora ${ }^{437}$. No seguro coletivo, há o estipulante ${ }^{438}$; no seguro sobre a vida de outrem, o contratante; e, em qualquer caso, na cobertura do risco de morte, há necessariamente o beneficiário. Questiona-se, com recorrência, na doutrina, de quem incumbe exigir, e em que momento, o interesse legítimo.

\footnotetext{
${ }^{434}$ TZIRULNIK, Ernesto; CAVALCANTI, Flávio de Queiroz B.; PIMENTEL, Ayrton. O contrato de seguro no novo Código Civil brasileiro, p. 163.

${ }^{435}$ Nesse sentido: "El interés debe existir al tiempo de la celebración del contrato. Su desaparición posterior es indiferente porque no es la medida de la indemnización" (HALPERIN, Isaac. El contrato de seguro, p. 440).

${ }^{436}$ Não se trata, porém, de obrigar a seguradora a realizar exames prévios nos seguros, pois isso significaria aceitar que o segurado não fosse obrigado a prestar informações conforme a boa-fé e a veracidade, como exige o art. 765, sob pena de aplicação do art. 766, ambos do Código Civil hodierno. A Jurisprudência, contudo, vem se posicionando em sentido oposto: "A teor do entendimento desta Corte, a seguradora não pode esquivar-se do dever de indenizar alegando que o segurado omitiu informações sobre seu estado de saúde quando não lhe foi exigido exames clínicos prévios, como ocorre in casu. Precedentes." (REsp 811617/ AL. Rel. Min. Jorge Scartizzi, j. em 21.12.2006).

${ }^{437}$ Consoante abordado, não se trata de fenômeno restrito ao seguro de pessoas, pois o seguro de danos também pode contar com outros figurantes; mas as peculiaridades relativas ao seguro de pessoas, principalmente no que tange às formas de contratação, exigem uma análise diferente daquela feita nos seguros de danos.

${ }^{438}$ Para efeitos deste trabalho, considera-se o estipulante como o contratante do seguro de pessoas em grupo referido no art. 801 do Código Civil, a fim de diferenciá-lo do contrante no seguro sobre a vida de terceiro.
} 


\subsubsection{Interesse do estipulante}

O estipulante ${ }^{439}$ é a pessoa física ou jurídica que contrata o seguro em proveito de um grupo de pessoas - denominado grupo segurável - que a ela se vincula.

Apesar de ser o responsável pela celebração do contrato-mestre ou apólicemestra $^{440}$ e pelo cumprimento de todas as obrigações contratuais, conforme dispõe o $\S 1^{\mathrm{o}}$ do art. 801 do Código Civil, o estipulante não é o segurado. Seguradas são as pessoas que integram o grupo segurável e aderem ou são incluídos no seguro, passando a formar, a partir desse momento, o grupo segurado. Uma vez parte do grupo segurado, a pessoa obtém a garantia individual com a seguradora e passa a ter direito próprio de exigi-la da seguradora $^{441}$.

Todavia, a despeito da necessária existência de uma relação entre o estipulante e os segurados do grupo, os riscos pesam somente sobre os interesses destes últimos; se, portanto, não tem interesse posto a risco, o estipulante, ainda que figure como contratante, não tem interesse segurável.

De acordo com o salientado, considerando o aspecto da formalidade, não é obrigatório que a contratação do seguro seja feita pelo segurado, que pode simplesmente aderir ao contrato celebrado pelo estipulante; todavia, mesmo na condição de aderente, o segurado tem um direito próprio e direto contra a seguradora para exigir a contraprestação securitária, salvo na garantia de morte, que deve ser, necessariamente, contratada em benefício de terceiro. Ao aderir ou ser incluído no contrato-mestre, o segurado passa a ter uma relação individual com a seguradora e o seu interesse é sobre a própria vida e os riscos inerentes à própria existência. É exatamente o mesmo interesse que teria se tivesse contratado o seguro sobre a própria vida, de forma individual.

\footnotetext{
${ }^{439}$ Apesar de constar apenas no capítulo relativo ao seguro de pessoas, é normal a contratação de seguro de dano por meio do estipulante, conforme se depreende do art. 767 do Código Civil; todavia, nessa modalidade o contratante é mais comumente denominado tomador.

${ }^{440}$ Conforme explicam Tzirulnik, Cavalcanti e Pimentel: "O contrato-mestre ou apólice-mestra contém todas as condições da garantia contratada em benefício do grupo: os riscos cobertos e excluídos, a forma de adesão ou de inclusão dos componentes do grupo segurável, a taxa do prêmio, início de vigência do contrato-mestre e das relações individuais, critérios determinadores da extinção, "enfim, tudo o que for do interesse da comunidade de riscos" (TZIRULNIK, Ernesto; CAVALCANTI, Flávio de Queiroz B.; PIMENTEL, Ayrton. O contrato de seguro de acordo com o novo código civil brasileiro, p. 195).

${ }^{441}$ PIMENTEL, Ayrton. O contrato de seguro de vida em grupo. Dissertação (Mestrado) - Faculdade de Direito da Universidade de São Paulo, 1978. f. 54-55.
} 
No magistério de Halperin ${ }^{42}$, apesar do direito dos segurados nascer do contrato celebrado com o estipulante, o direito de disposição deste último é limitado e se refere exclusivamente à administração do contrato ${ }^{443,444}$, e não à garantia prestada pelo segurador. O que se exige do estipulante é o vínculo ${ }^{445}$ com o grupo segurável, pressuposto necessário para o seguro em grupo, mas o interesse segurável é apenas do segurado.

\subsubsection{Interesse do contratante no seguro sobre a vida de outrem}

Reitera-se que o seguro sobre a vida do terceiro não se confunde com o seguro em grupo, apesar de, em ambos os casos, segurado e contratante serem pessoas distintas. No seguro coletivo, o contratante é o estipulante - objeto de abordagem no tópico anterior -, que contrata em benefício de um grupo de pessoas. No seguro sobre a vida do terceiro, o contratante contrata em seu próprio benefício, mas o risco incide sobre a vida de terceiro.

No seguro coletivo, o titular do interesse segurável é o segurado, ao passo que no seguro sobre a vida de terceiro o titular do interesse segurável é o contratante.

O seguro sobre a vida de outrem é a modalidade que mais gera controvérsias no que tange ao interesse segurável. Para evitar que esse tipo de seguro se transforme em uma aposta e, principalmente, que a sua contratação se transforme em um incentivo ao homicídio, é imprescindível a existência, entre o contratante e o terceiro, de um vínculo que justifique a contratação de um seguro sobre a pessoa desse último.

Nessa modalidade, existem duas correntes legislativas: a que exige apenas o consentimento do terceiro cuja vida se assegura (caso da Lei de Seguros francesa, do Código Civil italiano e da Lei argentina); e aquela que exige a declaração do interesse do

\footnotetext{
${ }^{442}$ HALPERIN, Isaac. El contrato de seguro, p. 472.

${ }^{443} \mathrm{E}$, mesmo no que se refere à administração, o estipulante depende da anuência expressa dos segurados que representem três quartos do grupo, consoante disposto no $\S 2^{\underline{0}}$ do art. 802 do Código Civil em vigor.

${ }^{444}$ Pimentel salienta que o estipulante, na vigência do contrato, atua como mandatário dos segurados; todavia, pratica outros atos que lhe são típicos, sem serem decorrentes da situação de mandatário - por exemplo, pagar o prêmio global e manter o grupo com o número mínimo de segurados exigidos (PIMENTEL, Ayrton. $O$ contrato de seguro de vida em grupo, p. 55).

${ }_{445}$ Tzirulnik, Cavalcanti e Pimentel explicam que, "Pelo texto legal, o vínculo tanto pode ser a relação de emprego com um mesmo empregador, como o de associado a uma mesma associação, etc., bastando que o vínculo seja anterior e externo ao contrato de seguro. O grupo ao qual o estipulante se vincule não pode ter como objetivo a obtenção do seguro" (TZIRULNIK, Ernesto; CAVALCANTI, Flávio de Queiroz B.; PIMENTEL, Ayrton. O contrato de seguro de acordo com o novo Código Civil brasileiro, p. 202).
} 
contratante. O Código Civil brasileiro de 2002 se filiou a esta última corrente, ao teor do caput do art. 790 do Código Civil brasileiro: "No seguro de vida sobre a vida de outros, o proponente é obrigado a declarar, sob pena de falsidade, o seu interesse pela preservação da vida do segurado".

A exigência de simples consentimento do terceiro em vez do interesse segurável do contratante resulta do fato de que tais legislações não reconhecem o interesse legítimo no seguro de pessoas, mas somente no seguro de dano. Consoante assinalado, a noção de interesse segurável depende essencialmente da própria definição do contrato de seguro que, por sua vez, varia de acordo com as várias teorias desenvolvidas sobre o tema e de sua influência na legislação ${ }^{446}$.

Halperin $^{447}$ destaca que a doutrina do interesse é um sistema superior ao do consentimento, pois este último permite a ocultação de uma aposta, uma vez que não garante a existência efetiva de um interesse na vida do terceiro ${ }^{448}$. De fato, mesmo com consentimento do terceiro, não é concebível que alguém contrate um seguro sobre a vida de outrem, quando não há qualquer interesse na preservação dessa vida; por isso, a inquestionável superioridade do instituto do interesse segurável como meio de evitar o desvio da função securitária e o moral hazard antes referido ${ }^{449}$.

Discute-se, porém, o tipo de natureza do interesse exigido nesse caso: se necessariamente econômico ou se também moral.

O parágrafo único do art. 790 presume a existência do interesse quando o segurado é cônjuge, ascendente ou descendente do proponente. A presunção legal decorre do vínculo afetivo existente entre cônjuges ${ }^{450}$ e pelo estreito vínculo familiar que une pais e filhos.

\footnotetext{
${ }^{446}$ PROVOST, Magalie. La notion d'intérêt d'assurance, p. 30-32.

${ }^{447}$ HALPERIN, Isaac. El contrato de seguro, p. 438.

${ }^{448}$ No mesmo sentido: TZIRULNIK, Ernesto; CAVALCANTI, Flávio de Queiroz B.; PIMENTEL, Ayrton. O contrato de seguro de acordo com o novo Código Civil brasileiro, p. 165.

449 Também essa é a opinião esposada por Provost, para quem a exigência de um consentimento constitui mero paliativo, que não substitui a função do interesse segurável de evitar que o seguro se transforme em uma aposta (PROVOST, Magalie, op. cit., p. 101).

${ }^{450}$ Entende-se que, apesar de o artigo se referir apenas à figura do cônjuge, aplica-se também aos companheiros, tal como reconhecido pelo art. 1.723 do Código Civil e assegurado pela Constituição Federal, art. 226, $\S 3^{\circ}$. Nesse sentido: TEPEDINO, Gustavo; BARBOSA, Heloisa Helena; MORAES, Maria Celina Bodin. Código Civil interpretado conforme a Constituição da República, v. II, p. 600. Para Delgado, porém, "o legislador não equiparou o companheiro ao cônjuge. Para aquele ser aceito como segurado, o proponente deve comprovar e o segurador exigir a prova da união estável na forma do art. 1.723" (DELGADO, José Augusto. Comentários ao novo Código Civil, p. 728). Na mesma trilha de Delgado, SANTOS, Ricardo Bechara. Direito do seguro no novo Código Civil e legislação própria, p. 386.
} 
Note-se, todavia, que o novo Código excluiu desse rol o irmão, que constava do Código de 1916, demonstrando ainda maior rigor nas hipóteses de presunção do interesse.

A regra legal não qualifica o interesse que se presume no vínculo conjugal ou familiar. Parte da doutrina entende que é essa a única hipótese em que o interesse de preservação pode ser de índole moral e não necessariamente econômica. Nesse sentido é a opinião de Tzirulnik, Cavalcanti e Pimentel: "O interesse afetivo, desprovido de conteúdo econômico, somente é admissível nas hipóteses do parágrafo único"451. Também para Ascarelli, o interesse do contratante pode ser exclusivamente moral ${ }^{452}$, sendo esse o fundamento para a presunção do interesse entre cônjuges, ascendentes e descendentes ${ }^{453}$, já que cumprida sua função inibitória atinente à verificação do sinistro.

$\operatorname{Delgado}^{454}$, por sua vez, propugna que a presunção prevista no parágrafo único também se refere exclusivamente ao interesse econômico, que é a hipótese do caput. Bechara acrescenta que "a presunção do interesse guarda também relação com a dependência econômica e alimentar desses proponentes com o segurado"455.

Aquilatar a natureza do interesse no parágrafo único não é mero preciosismo acadêmico, pois que se trata de mera presunção relativa, que admite prova em contrário ${ }^{456}$. Sustenta-se, neste estudo, que a referida prova em contrário incumbe, precipuamente, ao terceiro, cuja vida é assegurada e, apesar do caput, de fato, indicar que o interesse ali mencionado é de cunho econômico, é possível sustentar que o interesse presumido no parágrafo único pode ser de índole moral. Entende-se que, nesses casos, o interesse moral é ainda mais forte do que o econômico. Mesmo que inexista a dependência econômica, o vínculo afetivo entre cônjuges e familiares garante o interesse de preservação, com mais vigor do que o interesse pecuniário. E eventual manifestação do terceiro demonstrando que esse interesse de afeição inexiste, ainda que presente a dependência financeira, deve ser

\footnotetext{
${ }^{451}$ TZIRULNIK, Ernesto; CAVALCANTI, Flávio de Queiroz B.; PIMENTEL, Ayrton. O contrato de seguro de acordo com o novo Código Civil brasileiro, p. 165.

${ }^{452}$ Segundo Ascarelli, no Direito inglês, o interesse deve ser necessariamente pecuniário (ASCARELLI, Tullio. O conceito unitário do contrato de seguro. In: Problemas das sociedades anônimas e Direito Comparado, nota de rodapé 111, p. 235).

${ }^{453}$ Consoante sustenta Clovis Bevilacqua, a justificação da norma é posta no vínculo afetivo e, portanto, na normal existência de um interesse moral (ASCARELLI, Tullio, op. cit., p. 234).

${ }^{454}$ DELGADO, José Augusto. Comentários ao novo Código Civil, p. 726.

${ }^{455}$ SANTOS, Ricardo Bechara. Direito do seguro no novo Código Civil e legislação própria, p. 385-386.

${ }^{456}$ Nesse sentido: TZIRULNIK, Ernesto; CAVALCANTI, Flávio de Queiroz B.; PIMENTEL, Ayrton, op. cit., p. 165; e, também, DELGADO, José Augusto, op. cit., p. 165; e SANTOS, Ricardo Bechara, op. cit., p. 385 .
} 
suficiente para impedir a celebração ou mesmo o prosseguimento do seguro pelo segurador.

À exceção das hipóteses previstas no parágrafo único, o interesse deve ser necessariamente de cunho econômico ${ }^{457}$, sob pena da declaração de interesse assumir um caráter subjetivo, que não permita o adequado exame pelo segurador, a quem incumbe verificar o preenchimento da exigência legal.

\subsubsection{Interesse do beneficiário}

Por razões óbvias, o pagamento do capital no risco de morte é feito a um terceiro, denominado beneficiário. O beneficiário é, como o próprio nome evidencia, a pessoa em cujo benefício o seguro é contratado, e, portanto, aquele que receberá a soma segurada em caso de realização do risco de morte previsto no contrato ${ }^{458}$. Com a morte do segurado, o beneficiário adquire um direito próprio ao capital estipulado, não lhe sendo exigida nem a demonstração de seu interesse sobre a vida do segurado, nem do dano sofrido em decorrência da morte do primeiro.

Na verdade, o capital segurado pode, até mesmo, significar uma vantagem para o beneficiário, que não era dependente economicamente do segurado ou, até, que este vivia às expensas daquele, tornando-se sua morte uma economia. O pagamento da soma segurada, portanto, não está subordinado à existência de um dano, tampouco é vedado que constitua uma verdadeira vantagem para o beneficiário.

O art. 1.474 do Código Civil de 1916 vedava que uma pessoa legalmente inibida de receber doação do segurado pudesse ser nomeada como beneficiário. A norma era invocada principalmente ${ }^{459}$ na hipótese do art. 1.177 do diploma em comento, relativa à anulabilidade da doação do cônjuge adúltero ao seu cúmplice, atualmente prevista no art.

\footnotetext{
${ }^{457}$ Esse é o posicionamento doutrinário de TZIRULNIK, Ernesto; CAVALCANTI, Flávio de Queiroz B.; PIMENTEL, Ayrton. O contrato de seguro de acordo com o novo Código Civil brasileiro, p. 165; e também de DELGADO, José Augusto. Comentários ao novo Código Civil, p. 727. Ressalte-se, ainda, o entendimento de Bechara, para quem o interesse deve ser não só econômico, mas também jurídico (SANTOS, Ricardo Bechara. Direito do seguro no novo Código Civil e legislação própria, p. 386).

${ }^{458}$ PROVOST, Magalie. La notion d'intérêt d'assurance, p. 314.

${ }^{459}$ Mas não só nesse caso. A legislação veda também o recebimento da indenização pelo beneficiário quando este foi o causador da morte do segurado.
} 
550 do Código hodierno ${ }^{460}$ A previsão do art. 1.474, no entanto, não foi repetida no novo Código. Comparato, ao justificar a nova legislação, assevera que a vedação anterior persiste, "como irrecusável imposição moral social e da própria lógica jurídica ${ }^{461}$, mas positivou-se no atual art. 793 a orientação jurisprudencial majoritária de que "é válida a instituição do companheiro como beneficiário, se ao tempo do contrato o segurado era separado judicialmente, ou já se encontrava separado de fato".

Com efeito, exige-se que o proponente declare a natureza de seu vínculo com o beneficiário que está sendo designado. Provost entende que a exigência da declaração do vínculo para a nomeação do beneficiário é um indicativo de que, também por parte desse último, é exigido um interesse segurável? A autora coloca a seguinte hipótese: imagine-se que um pai contrata um seguro de vida para o filho, designando um terceiro como beneficiário. De quem deve ser exigido o interesse segurável: do contratante (pai), do segurado (filho) ou do beneficiário (terceiro) ${ }^{462}$ ?

No Brasil, a questão seria respondida, ao menos aparentemente ${ }^{463}$, com facilidade: o interesse segurável deve ser exigido do contratante (pai), conforme disposto no art. 790 do Código Civil, pois se trata de seguro sobre a vida de terceiro (filho). O interesse, porém, é presumido, enquadrando-se na previsão do parágrafo único do mesmo artigo, de relação entre descendentes.

Provost defende que, para verificar quem é o titular do interesse, deve-se analisar quem pode lucrar com o seguro, transformando-o em uma aposta. No exemplo dado, o contratante, de um lado, se não é o segurado, não suporta as consequências do risco; de outro, se não for o beneficiário, também não recebe a indenização securitária. Exigir do contratante o interesse não impede, pois, que a finalidade do seguro seja desviada. Se a

\footnotetext{
460 "Art. 550. A doação do cônjuge adúltero ao seu cúmplice pode ser anulada pelo outro cônjuge, ou por seus herdeiros necessários, até 2 (dois) anos depois de dissolvida a sociedade conjugal."

${ }^{461}$ COMPARATO, Fabio Konder. Substitutivo ao capítulo referente ao contrato de seguro no anteprojeto de Código Civil, p. 149-150.

${ }^{462}$ PROVOST, Magalie. La notion d'intérêt d'assurance, p. 315. O autor cita o projeto de lei francês que prevê, no art. 85, que cada parte deve ter um interesse segurável que justifique a contratação (ibidem, p. 320). 463 "Aparentemente" porque o exemplo de Provost mais se assemelha a um seguro em favor de terceiro do que sobre a vida de terceiro. No seguro sobre a vida de terceiro, o contratante é o próprio beneficiário. Nessa linha, Tzirulnik, Cavalcanti e Pimentel dizem: "[...] o contratante celebra o contrato, assume todas as obrigações contratuais e se coloca como beneficiário do seguro, por ser titular do interesse garantido pelo seguro. Morto o segurado, terá o contratante direito próprio, perante a seguradora, ao recebimento do capital segurado." (TZIRULNIK, Ernesto; CAVALCANTI, Flávio de Queiroz B.; PIMENTEL, Ayrton. O contrato de seguro no novo Código Civil brasileiro, p. 164).
} 
finalidade do interesse é evitar que o seguro se transforme em uma aposta, o interesse deve ser exigido daquele que pode se beneficiar disso, ou seja, do beneficiário ${ }^{464}$.

O posicionamento da autora é severamente criticado por muitos doutrinadores ${ }^{465}$, pois o beneficiário não participa da contratação, não está submetido a risco, pode ser indeterminado e, mesmo determinado, pode ser substituído a qualquer tempo pelo segurado, inclusive por disposição de última vontade, salvo quando tiver como causa declarada a garantia de uma obrigação, conforme dispõe o art. 791 do Código Civil. Pela norma brasileira, a designação é ato unilateral, que não necessita de aceitação do beneficiário $^{466}$; ademais, se o interesse segurável é elemento essencial do contrato, não pode depender de quem não é parte contratante, sob pena de ferir, inclusive, o princípio da relatividade dos contratos ${ }^{467}$.

Provost contra-argumenta sustentando que a eventual indeterminação do beneficiário do contrato não é um obstáculo à verificação de seu interesse. Se o seguro de vida é uma estipulação em favor de um terceiro, que passa, com a ocorrência do risco, a ser credor da seguradora, esse terceiro deve ser levado em conta na formação do contrato, pois é essa a única forma de evitar a aposta por meio do seguro ${ }^{468}$.

Para a autora, no seguro de dano, o interesse segurável também é exigido do beneficiário. A diferença decorre do fato que, por se submeter ao princípio indenitário, o segurado, cujo patrimônio está sujeito a risco, é quem será indenizado pelo dano eventualmente sofrido, sendo, portanto, o beneficiário da indenização. Se quem receber a indenização não tiver sofrido o dano, então o seguro passará a propiciar um lucro em vez de um ressarcimento. Em razão dessa identificação entre o segurado e o beneficiário no seguro de dano, muitas legislações empregam o termo segurado, quando, segundo Provost, na verdade se referem ao beneficiário ${ }^{469}$.

Entende-se, neste estudo, que o princípio indenitário impede que o beneficiário no seguro de dano, seja equiparado ao beneficiário no seguro de pessoas. Consoante exposto, no seguro de dano há uma função ressarcitória que inexiste no seguro de pessoas. E o

\footnotetext{
${ }^{464}$ PROVOST, Magalie. La notion d'intérêt d'assurance, p. 319-321.

${ }^{465}$ Ibidem, p. 326-327.

${ }^{466}$ Cf. TZIRULNIK, Ernesto; CAVALCANTI, Flávio de Queiroz B.; PIMENTEL, Ayrton. O contrato de seguro no novo Código Civil brasileiro, p. 170.

${ }^{467}$ PROVOST, Magalie, op. cit., p. 326.

${ }^{468}$ Ibidem, p. 327.

${ }^{469}$ Ibidem, loc. cit.
} 
interesse segurável não pode ser exigido de quem não participa do contrato, que não tem relação com um bem sujeito a risco.

Isso não significa a inexistência de regras no ordenamento jurídico para a designação do beneficiário. Consoante preconiza o art. 792 do Código Civil brasileiro:

"Na falta de indicação da pessoa ou beneficiário, ou se por qualquer motivo não prevalecer a que for feita, o capital segurado será pago por metade ao cônjuge não separado judicialmente, e o restante aos herdeiros do segurado, obedecida a ordem de vocação hereditária".

E, conforme dicção do parágrafo único do dispositivo em comento: "Na falta das pessoas indicadas neste artigo, serão beneficiários os que provarem que a morte do segurado os privou dos meios necessários à subsistência”.

Aventa-se, pois, expressamente na legislação pátria, que a designação do beneficiário pode não prevalecer. Hipóteses típicas são a do beneficiário do cônjuge adúltero, ou a do beneficiário que assassina o segurado. Nessas situações, o beneficiário não tem direito à indenização, mas isso não afeta o contrato de seguro celebrado entre o segurado e a seguradora. Caso se tratasse de perda do direito por falta de interesse segurável, elemento essencial do contrato, a própria existência do seguro estaria afetada. Mas não é o que ocorre. O contrato sobrevive e a indenização securitária deverá ser paga àquele beneficiário apto a receber a soma segurada. Como já explicava Pontes de Miranda, se houver dois beneficiários, e apenas um estiver impedido, o outro nomeado recebe a prestação securitária $^{470}$.

O interesse segurável desempenha papel essencial no contrato de seguro e não pode ser negligenciado, sob pena de o seguro não atender aos seus fins sociais. Sua aplicação, no entanto, também não deve extrapolar o escopo definido e engessar a operação securitária; ao contrário, é o interesse segurável, objeto do contrato, elemento existente em qualquer modalidade, que permite a perfeita compreensão e interpretação da finalidade do contrato e dos seus reflexos para as partes. Por meio dele, garante-se que o seguro não seja desviado de seu objetivo, tão essencial no mundo contemporâneo, de socialização dos riscos, e não como instrumento de lucro ou especulação.

${ }^{470}$ PONTES DE MIRANDA, Francisco Cavalcanti. Tratado de Direito Civil, t. XLVI, § 4.963, p. 25-26. 


\section{CONCLUSÃO}

Este trabalho teve por escopo o estudo, do ponto de vista jurídico, do interesse segurável, tema essencial à compreensão do contrato de seguro, em especial após o advento do Código Civil de 2002. A pesquisa foi desenvolvida tendo por base a análise estrutural e funcional do interesse segurável, sua evolução legislativa no Brasil e consequências no contrato de seguro, no que alude tanto ao seguro de danos como ao seguro de pessoas. A análise pautou-se, em particular, no Código Civil hodierno em comparação com o Código de 1916. Quando pertinente, o estudo foi ilustrado com o tratamento da matéria nas legislações e precedentes estrangeiros, na Jurisprudência brasileira e no Projeto de Lei n. 3.555/2004. A inexistência de literatura nacional específica sobre o assunto corrobora a importância do estudo do objeto em foco. Trata-se, contudo, de uma primeira esquematização da matéria, sem a pretensão de esgotá-la. Dessa investigação, emergiram as principais conclusões apontadas a seguir:

1. O significado de interesse se modificou ao longo do tempo. Na sua origem, tem uma acepção essencialmente econômica de proveito financeiro. Passa, então, a designar qualquer tipo de vantagem ou utilidade entre pessoas e bens. Atualmente pode expressar desde um sentimento de conveniência e avidez, como também um sentido de importância, de curiosidade ou zelo. Em sua acepção jurídica, indica uma relação de utilidade ou de necessidade entre uma pessoa e um bem.

2. Do ponto de vista securitário, interesse expressa um intuito de conservação dessa relação de utilidade entre sujeito e bem. Tem interesse aquele cuja destruição ou perda dessa relação mostra-se desvantajosa. Por isso, para ser segurável, o interesse deve estar exposto a risco.

3. A noção de interesse segurável surge com o seguro marítimo, objetivando evitar que a indenização securitária seja utilizada como fonte de lucro, em vez de reparação de dano. Desenvolve-se, assim, estreitamente ligada ao seguro de 
dano, a fim de garantir que o segurado, beneficiário da indenização, não tenha interesse na realização do risco.

4. Os seguros de pessoas enfrentam óbices morais, desenvolvendo-se posteriormente ao seguro de danos. Diante da dificuldade de uma valoração objetiva da vida humana e da não aplicação do princípio indenitário, os seguros de pessoas constituíram uma modalidade distinta de contratação em diversas legislações, não prevendo a figura do interesse segurável.

5. Várias teorias buscaram um conceito unitário para o contrato de seguros, destacando-se a Teoria Indenitária, a Teoria da Necessidade, a Teoria de Empresa, a Teoria da Transferência do Risco e a Nova Teoria Indenitária.

6. No Brasil, adotou-se o conceito unitário do contrato de seguro, definido como aquele pelo qual "o segurador se obriga mediante o pagamento do prêmio, a garantir interesse legítimo do segurado, relativo à pessoa ou coisa, contra riscos predeterminados" (art. 757 do Código Civil de 2002). Sobressai-se, assim, o interesse segurável, como elemento unificador e objeto do contrato, seja no seguro de dano, seja no seguro de pessoas.

7. A principal definição de interesse foi dada pelo doutrinador alemão Ehrenberg. Aplicável, no início, apenas aos seguros de dano, o conceito foi aprimorado para designar o interesse segurável como a relação existente entre uma pessoa e um bem, ameaçada por um risco determinado. Outras correntes, aplicáveis apenas ao seguro de dano, definem o interesse como o próprio valor do bem, suscetível de perda em razão do sinistro ou, ainda, como uma expectativa de perda patrimonial.

8. Em face de sua definição majoritária, emergem os seguintes elementos constitutivos do interesse: o bem, a relação e sua exposição a um risco determinado.

9. O bem é o objeto da relação ao qual o interesse segurável se reporta. Pode ser uma coisa, uma pessoa ou mesmo um direito, como o qual o sujeito tenha uma relação. É o bem, como objeto do interesse, que identificará o seguro como de coisa, de responsabilidade ou de pessoas. No seguro de coisa, o bem objeto do interesse é uma coisa concretamente determinada, que integra o patrimônio do segurado. No seguro de responsabilidade, o bem, objeto do interesse, é o 
próprio patrimônio como um todo. No seguro de pessoas, o bem objeto do interesse é a pessoa humana.

10. A relação é o vínculo que liga o sujeito ao bem. De acordo com a doutrina majoritária, pode ser tanto jurídica como de fato, desde que socialmente relevante e protegida pela ordem jurídica. Sua natureza é essencialmente econômica. Nos seguros de pessoas, algumas legislações admitem também o interesse de índole moral, em casos específicos, como nas relações entre ascendentes e descendentes e entre marido e mulher.

11. Seja qual for o seu conteúdo, a relação deve estar claramente fixada no contrato, a fim de possibilitar a correta delimitação do risco pelo segurador.

12. A exposição ao risco é a condição para que o interesse seja segurável. O risco é a possibilidade de ocorrência de um evento capaz de afetar o bem ou a relação, acarretando um dano ou uma desvantagem para o segurado. Os riscos ou espécies de ricos devem ser pré-determinados no contrato.

13. Há, portanto, clara interdependência entre interesse e risco: a cessação do risco não afeta o interesse, mas extingue sua assegurabilidade. Já a cessão do interesse elimina o risco, pois este somente pode incidir sobre interesse existente.

14. O interesse segurável é legítimo, portanto, quando demonstrado que seu titular possui uma relação juridicamente protegida com o bem, que autoriza a contratação do seguro, porque dela decorre o fato de que o risco de sua perda é indesejado ou tem consequências indesejadas e, por isso, há interesse na sua conservação e, portanto, na contratação da proteção securitária.

15. A exigência do interesse legítimo visa impedir o moral hazard, que é justamente o perigo de que a contratação do seguro gere no segurado um comportamento diferente daquele que teria se o seguro não existisse. Nos seguros de danos, essa função é exercida cumulativamente com o princípio indenitário.

16. Dos diferentes tratamentos legislativos decorre a ausência de consenso sobre a qualificação jurídica do interesse segurável. No Brasil, o interesse é considerado elemento categorial inderrogável do contrato de seguro, assim como risco, prêmio e garantia. 
17. A doutrina majoritária propugna que prêmio e garantia configuram as prestações essenciais das partes; o prêmio é preço pago pelo segurado para obter a garantia securitária pelo período de vigência do contrato. Parcela minoritária da doutrina defende, porém, que a prestação da seguradora é a indenização, devida somente quando ocorrido o risco previsto no contrato. A divergência decorre da qualificação do contrato como comutativo ou aleatório. $\mathrm{O}$ entendimento majoritário apregoa a natureza comutativa do contrato de seguro e a garantia como a prestação de segurança assumida pelo segurador, compreensiva do eventual dever de pagar a indenização ou soma segurada.

18. A definição de interesse segurável traz ínsita a ideia de conservação de determinado bem, contra um risco que o ameaça. Trata-se de noções complementares que constituem o cerne do contrato e definem as prestações das partes. O risco incidente sobre o interesse é elemento essencial para o cálculo do prêmio e o objeto da garantia contratual é o interesse submetido a risco.

19. Parte da doutrina defende que a organização técnica-empresarial da seguradora foi elevada à categoria de elemento pelo legislador, por força do caput do art. 757 do Código Civil. Não há, ainda, consenso doutrinário sobre o tema.

20. No tratamento legislativo brasileiro, o interesse segurável é o objeto do contrato de seguro. Nessa qualidade, é o interesse que condiciona o conteúdo do contrato, permitindo distintos seguros sobre o mesmo bem e determinando seu valor. Referido posicionamento é defendido por parcela expressiva da doutrina, mesmo em países cuja legislação não adota um conceito unitário para o contrato de seguro centrado no interesse.

21. Parte da doutrina estrangeira qualifica o risco como objeto do contrato, e o interesse na não ocorrência de um risco é qualificado ora como causa, ora como requisito de validade dos seguros de dano. A crítica essencial a esses posicionamentos é que o interesse não se confunde com a causa subjetiva e tampouco constitui fator externo à relação negocial. O interesse se identifica com a própria relação que vincula o sujeito ao bem e que é passível de ser afetada pelo risco. Trata-se, portanto, de objeto da garantia e, por consequência, de objeto do contrato de seguro. 
22. Os seguros de dano têm por característica essencial a aplicação do princípio indenitário, segundo o qual o seguro não pode ser fonte de lucro para o segurado. Subdividem-se em seguros de danos diretos ou de coisa e seguros de dano indiretos ou de responsabilidade. Distinguem-se relativamente ao seu objeto e aos riscos a que estão sujeitos.

23. O objeto do interesse, nos seguros de coisa, é um bem determinado ou determinável que integra o patrimônio do segurado, podendo ser uma coisa ou um direito $\mathrm{O}$ dano sofrido afeta diretamente o segurado. No seguro de responsabilidade, o interesse se reporta ao patrimônio como um todo e quem sofre o dano de forma direta é o terceiro, em decorrência de ato do segurado que caracterize sua responsabilidade.

24. Um mesmo bem pode ser objeto de diversos interesses, dando origem a diferentes seguros. De acordo com a classificação de Ferrarini, adotada para o fim do presente trabalho, esses interesses podem ser compreendidos como interesse material, interesse concorrente ou interesse sobre lucro, de acordo com os sujeitos legitimados a contratar.

25. O interesse material é aquele sobre a própria matéria do bem. É o interesse típico do proprietário, que suporta os danos decorrentes da destruição ou perda do bem, independentemente de qualquer outro fato ou relação incidente sobre o mesmo bem.

26. Os interesses concorrentes referem-se a outros interesses coexistentes na conservação do bem que concorrem com o interesse material. Tanto o titular do interesse material como o titular do interesse concorrente estão legitimados a celebrar o contrato de seguro. A indenização securitária, porém, não necessariamente deve ser paga ao contratante, mas sim ao titular do interesse segurado.

27. Tem interesse sobre lucro aquele que possui uma fundada expectativa de extrair determinado proveito do bem. A doutrina diverge se, ao garantir o interesse material ou concorrente, estará também garantido o interesse sobre lucro. A posição majoritária é a de que a garantia do interesse sobre lucro depende de contratação específica. 
28. No seguro de coisa, exige-se uma correspondência entre o valor do interesse segurável e a garantia contratada. O valor do interesse segurável é o prejuízo máximo a que o interesse está sujeito. $\mathrm{O}$ valor segurado é aquele que se atribui ao interesse no momento da contratação e representa o limite de garantia do contrato. $\mathrm{O}$ valor do interesse, em regra, deve ser aferido por critérios objetivos, de acordo com o valor econômico da relação sujeita a risco.

29. A contratação de garantia por valor maior do que o interesse segurável caracteriza sobresseguro e é vedada pela legislação securitária de forma geral, por se tratar de decorrência da aplicação do princípio indenitário. No Brasil, de acordo com os arts. 778 e 766 do Código Civil, a sanção pelo sobresseguro depende da demonstração da boa-fé ou da má-fé na atribuição do valor excessivo. No primeiro caso, a indenização é devida, mas limitada ao valor do interesse e do prejuízo sofrido, facultando-se ao segurador a cobrança da diferença de prêmio. No segundo caso, há a perda do direito à garantia sem restituição do prêmio.

30. A contratação de garantia por quantia inferior ao valor do interesse segurável denomina-se infrasseguro e não é vedada por lei; todavia, a indenização será reduzida na mesma proporção da diferença entre o valor segurado e o valor segurável, por força da regra de rateio positivada no art. 783 do Código Civil de 2002.

31. O fundamento do infrasseguro é a insuficiência do prêmio, cujo cálculo leva em conta o valor da coisa segura. Apesar de se tratar de prática securitária consagrada, a redução da indenização é questionável nos casos em que a garantia contratada corresponde ao interesse segurável no momento da celebração, mas há alteração posterior do interesse por fato alheio à vontade ou atuação do segurado.

32. A contratação de um seguro sobre o mesmo interesse e contra o mesmo risco com outro segurador caracteriza a pluralidade de seguros. A prática não é vedada, mas há obrigação de comunicação prévia e por escrito ao primeiro segurador, indicando a segurada pretendida, a fim de que a soma das garantias não exceda o valor do interesse. 
33. O interesse no seguro de responsabilidade refere-se ao patrimônio do segurado contra os riscos de responsabilidade civil por danos causados a terceiros. A contratação do seguro de responsabilidade civil é obrigatória quando for imposta pelo Estado e facultativa quando livremente estipulada pelo segurado.

34. O Código Civil hodierno estabeleceu regimes jurídicos diversos para cada modalidade, em função do interesse tutelado. Os seguros de responsabilidade legalmente obrigatórios têm caráter social e tutelam o interesse da vítima, a quem deve ser paga eventual indenização.

35. A doutrina diverge relativamente ao interesse tutelado no seguro facultativo de responsabilidade civil. Parte da doutrina entende que o contrato visa garantir apenas o interesse do segurado relativamente ao seu próprio patrimônio. Outra parcela defende que o seguro tutela tanto o interesse do segurado como o da vítima; e uma terceira apregoa que o interesse garantido é o do terceiro. A previsão de regimes jurídicos diversos demonstra, porém, que o interesse garantido é o do próprio segurado; todavia, não se exige que o pagamento da indenização securitária seja feito na forma de reembolso ao segurado, mas sim diretamente à própria vítima, desde que se trate de risco coberto e sejam respeitados os limites contratuais.

36. O interesse no resseguro assume os mesmos contornos do seguro de responsabilidade civil relativamente à preservação do patrimônio da seguradora-ressegurada contra os riscos do exercício da atividade securitária.

37. O fato do interesse segurável, no seguro de responsabilidade civil, ter por objeto o patrimônio do segurado dificulta ou impede a determinação do valor segurável, pois não é possível medir a exposição do patrimônio ao risco. Por isso, não se aplicam as regras relativas ao sobresseguro, ao infrasseguro .

38. Nos seguros de pessoas, o interesse tem por objeto a própria pessoa humana, contra os riscos da existência humana, não possuindo a função ressarcitória típica dos seguros de danos, sendo-lhe inaplicável o princípio indenitário. A exceção é o seguro-saúde, que tem natureza indenitária e se submete ao regime do seguro de dano.

39. No que tange ao risco, as duas principais modalidades são os seguros de vida e de acidentes pessoais. $\mathrm{O}$ primeiro garante o interesse contra os riscos de morte 
ou de sobrevivência após determinada idade; no caso do segundo, os riscos são de invalidez ou morte por acidente.

40. No tocante à forma de contratação, os seguros podem ser individuais ou coletivos. Na segunda modalidade, o seguro é contratado por uma pessoa física ou jurídica denominada estipulante em proveito de um grupo que a ela se vincule. $\mathrm{O}$ estipulante do seguro coletivo não tem interesse segurável. $\mathrm{O}$ titular do interesse é o segurado que integra o grupo segurável.

41. Diante da inaplicabilidade do princípio indenitário, não há limite para a estipulação do capital segurado, sendo permitida a contratação de mais de um seguro sobre o mesmo interesse; todavia, essa liberdade não é ilimitada nos casos em que se identifica uma função indenizatória, ainda que diferente daquela do seguro de dano. Em tais casos, a estipulação de capital manifestamente desproporcional à possibilidade de dano desnatura o interesse legítimo, já que a ocorrência do risco passa a ser vantajosa ao segurado.

42. No seguro sobre a vida do terceiro, deve o contratante demonstrar o interesse segurável que justifique a contratação de um seguro sobre a vida de outrem, por força do art. 790 do Código Civil brasileiro. Há legislações estrangeiras, porém, que não exigem a demonstração do interesse, apenas o consentimento de terceiro; contudo, o consentimento pode ocultar a contratação de um seguro concluído sem o interesse segurável, configurando um desvio da função securitária.

43. O interesse exigido para a contratação de um seguro sobre a vida de outrem é, necessariamente, de cunho econômico. Presume-se, porém, o interesse entre cônjuges e companheiros, bem como entre ascendentes e descendentes, por expressa disposição do parágrafo único do art. 790 do Código Civil. Apenas nessa hipótese, admite-se o interesse afetivo, desprovido de conteúdo econômico. A presunção legal, porém, é relativa, admitindo-se prova em contrário.

44. Não é exigível do beneficiário do capital estipulado para o risco de morte qualquer interesse segurável. A soma paga pela seguradora no seguro contra o risco de morte não visa ressarcir um dano, de forma que o beneficiário 
designado nesse caso não se confunde com o segurado, titular do interesse e beneficiário da indenização no seguro de dano.

Ao sintetizar os principais posicionamentos doutrinários alusivos aos aspectos centrais abordados neste trabalho, constata-se que a inovação do Código Civil de 2002 de colocar o interesse segurável como objeto do próprio contrato de seguro representou um inquestionável avanço no tratamento da matéria, seguindo orientação consagrada em outros modelos normativos. Apesar disso, o significado e os efeitos do interesse segurável no contrato de seguro, essenciais para a adequada compreensão da estrutura desse tipo de contrato, não foram ainda estudados com a profundidade merecida pela doutrina pátria. Espera-se, assim, contribuir para o debate e a clareza deste tema objeto de estudo e, em última análise, para o próprio contrato de seguro, instrumento complexo e de inquestionável relevância social. 


\section{REFERÊNCIAS}

ABRAHAM, Keneth S. Insurance and Regulation. 3rd. ed. New York: Foundation Press, 2000.

AGUIAR DIAS, José. Da responsabilidade civil. 3. ed. Rio de Janeiro: Forense, 1954. t. 2.

ALmeIDA, J. C. Moitinho de. Contrato de seguro: estudos. Coimbra: Coimbra, 2009.

O contrato de seguro no Direito português e comparado Lisboa: Sá da Costa, 1971.

ALVIM, Pedro. O contrato de seguro. 3. ed. Rio de Janeiro Forense, 1999.

O seguro e o novo Código Civil. Organização e compilação de Elizabeth Alvim Bonfioli. Rio de Janeiro: Forense, 2007.

AMARAL, Francisco. Direito Civil: introdução. 6. ed. rev., atual. e aum. Rio de Janeiro: Renovar, 2006.

ARAUJO, Vaneska Donato de. A responsabilidade profissional e a reparação de danos. 2011. 314 f. Dissertação (Mestrado em Direito do Trabalho) - Faculdade de Direito da Universidade de São Paulo, São Paulo, 2011.

ASCARELLI, Tullio. O conceito unitário do contrato de seguro. In:

Problemas das sociedades anônimas e Direito Comparado. São Paulo: Saraiva, 1945.

Problemas das sociedades anônimas e Direito Comparado. São Paulo:

Saraiva, 1945.

ASCENSÃO, José de Oliveira. Direito Civil e Teoria Geral. Coimbra: Coimbra, 2002. v. III.

ASSOCIATION INTERNATIONALE DE DROIT DES ASSURANCES - AIDA. Studi in onore di Antigono Donati, Roma, Rivista Assicurazioni, v I-III, 1970.

AZEVEDO, Álvaro Villaça de. O novo Código Civil brasileiro: tramitação, função social do contrato, boa-fé objetiva, teoria da imprevisão e, em especial, onerosidade excessiva "laesio enormis". In: DELGADO, Mario Luiz; ALVES, Jones Figueiredo (Coords.). 
Questões controvertidas no novo código civil. São Paulo: Método, 2004. p. 9-29. (Grandes Temas do Direito Privado, v. 2).

AZEVEDO, Antonio Junqueira de. Negócio jurídico: existência, validade e eficácia. 3. ed. São Paulo: Saraiva, 2000.

. Princípios do novo Direito Contratual e desregulamentação do mercado parecer. Revista dos Tribunais, São Paulo, v. 87, n. 750, p. 113-120, abr. 1998.

BARROS MONTEIRO, Washington de. Curso de Direito Civil - parte geral. 15. ed. São Paulo: Saraiva, 1980.

BETTI, Emilio. Teoria geral do negócio jurídico. Coimbra: Coimbra, 1969. t. II.

BICKELHAUPT, David L. General Insurance. Tenth Edition. Homewood, IL: Richard D. Irwin, Inc., 1979.

BIRDS, John. Modern Insurance Law. 2. ed. London: Sweet \& Maxwell, 1988.

BURANELLO, Renato Macedo. Do contrato de seguro - o seguro garantia de obrigações contratuais. São Paulo: Quartier Latin, 2006.

BUTTARO, Luca. L'interesse nell'assicurazione. Milano: Giuffrè, 1953.

CARNELUTTI, Francesco. Sistema di Diritto Processuale Civile. Padova: Cedam, 1936. v. I.

Teoria Generale del Diritto. 3. ed. Rome: Foro Italiano, 1951. v. I.

CARVALHO SANTOS, J. M. de. Código Civil brasileiro interpretado. 7. ed. Rio de Janeiro: Freitas Bastos, 1960. v. 19.

CAVALIERI FILHO, Sergio. O Direito do Consumidor no limiar do século XXI. Revista de Direito do Consumidor, São Paulo, v. 9, n. 35, p. 97-108, jul./set. 2000.

CINTRA, Antonio Carlos de Araújo et al. Teoria geral do processo. 9. ed. São Paulo: Malheiros, 1993.

. Notas retificadoras sobre seguro de crédito e fiança. In: Direito Empresarial: estudos e pareceres. São Paulo: Saraiva, 1990.

COMPARATO, Fabio Konder. Ensaios e pareceres do Direito Empresarial. Rio de Janeiro: Forense, 1978. . O seguro de crédito. São Paulo: RT, 1968. 
COMPARATO, Fabio Konder. Substitutivo ao capítulo referente ao contrato de seguro no anteprojeto de Código Civil. Revista de Direito Mercantil, ano XI, n. 5, p. 143-152, 1972.

COSTA, Judith Martins. Os campos normativos da boa-fé objetiva: as três perspectivas do direito privado brasileiro. Revista Forense, Rio de Janeiro, v. 101, n. 382, p. 119-143, nov./dez. 2005.

COUILBAULT, François; ELIASHBERG, Constant. Les grands principes de l'assurance. 7e. édition. Paris: L’Argus, 2005.

CUNHA, Antonio Geraldo da. Dicionário Etimológico Nova Fronteira da Língua Portuguesa. 2. ed. Rio de Janeiro: Nova Fronteira, 2001.

CWINYA-AI, Robert Ongon. What is necessary of insurable interest in insurance contracts? New Orleans, 2008. Disponível em: <http://ssrn.com/abstract=1407578>. Acesso em: 15 jan. 2011.

DELGADO, José Augusto. Comentários ao novo Código Civil. Rio de Janeiro: Forense, 2004. (Das várias espécies de contrato do seguro, v. XI).

DICIONÁRIO de Seguros do IRB Brasil Resseguros S/A. Disponível em: <http://www.irb-brasilre.com.br>. Acesso em: 15 fev. 2010.

DOBBYN, John. Insurance Law in a nutshell. $3^{\text {rd }}$ reprint. St. Paul, Minn.: West Publishing Co., 1994.

DONATI, Antigono. Trattato del Diritto delle Assicurazioni Private. Giuffrè: Milano, 1952. t. II.

DURANTE, Aldo. La responsabilità del professionista e la sua assicurazzione. Milano: Giuffrè, 1970.

ENGISCH, Karl. Introdução ao pensamento jurídico. 9. ed. Lisboa: Fundação Calouste Gulberkian, 2004.

FANELLI, Giuseppe. Le assicurazioni. Milano: Giuffrè, 1973. t. 1.

FERRARINI, Sergio. L'interesse nell'assicurazione. Pisa: Nistri-Lischi, 1935.

FRANCO, Vera Helena de Mello. Contratos no Direito Privado: direito civil e empresarial. São Paulo: Revista dos Tribunais, 2009.

Lições de direito securitário: seguros terrestres privados. São Paulo: Maltese, 1993. 
FREIRE, Numa. Aspectos do seguro. São Paulo: Atlas, 1959.

GARRIGUES, Joaquim. Algunas ideas sobre el interés en el seguro contra daños. In: ASSOCIAZIONE INTERNATIONALE DI DIRITTO DELLE ASSICURAZIONI AIDA. Studi in onore di Antigono Donati. Roma: Edizioni Della Rivista Assicurazioni, 1970. v. I.

GOMES, Orlando. Contratos. 5. ed. Rio de Janeiro: Forense, 1975. Introdução ao Direito Civil. 6. ed. Rio de Janeiro: Forense, 1979.

GREENE, Mark R. Riesgo y seguro. Madrid: Mapfre, 1974.

GUIMARÃES, Antonio Marcio da Cunha. Contratos Internacionais de Seguros. São Paulo: Revista dos Tribunais, 2002.

HALPERIN, Isaac. Accion, directa de la vitima contra el asegurador del responsible civil del dano. Buenos Aires: La Ley, 1944. El contrato de seguro. Buenos Aires: Tipografica, 1946.

HARTEN, Carlos. El deber de declaración del riesgo en el contrato de seguro: exposición crítica del modelo brasileño y estudio del Derecho Comparado. Salamanca: Ratio Legis, 2007.

HIRONAKA, Giselda Maria Fernandes Novaes (Coord.). A outra face do Poder Judiciário: decisões inovadoras e mudanças de paradigmas. Belo Horizonte: Del Rey/São Paulo, Escola Paulista de Direito, 2005.

HUEBNER, S. S.; BLACK JÚNIOR, Kenneth. El seguro de vida. Madrid: Mapfre, 1976. INSTITUTO BRASILEIRO DO DIREITO DO SEGURO. II Fórum de Direito do Seguro José Sollero Filho. São Paulo: Manuais Técnicos de Seguros: IBDS, 2002.

. III Fórum de Direito do Seguro José Sollero Filho. São Paulo: Manuais Técnicos de Seguros: IBDS, 2003.

IV Fórum de Direito do Seguro José Sollero Filho. São Paulo: IBDS, 2004.

INSTITUTO NAZIONALE DELLE ASSICURAZIONI. Studdi sulle assicurazioni: Raccolti in occasione del cinqüentenário dell'Instituto Nazionale delle Assicurazioni. Roma: Giuffrè, 1963.

ISDA Publishes Year-End 2008 Market Survey. Disponível em: www.isda.org/press/ press042209market.html. Acesso em: 15 fev. 2010. 
JHERING, Rudolf von. O espírito do Direito Romano III. Tradução de Rafael Benaion. Rio de Janeiro: Alba, 1943.

LUCENA -v- Craufurd (1802) 3 Bos \& P 75; (1802) 127 ER 42 Ex Ch. Disponível em: <http://www.swarb.co.uk/lisc/Insur18001849.php>. Acesso em: 10 nov. 2010.

MACEDO JUNIOR, Ronaldo Porto. Contratos relacionais e defesa do consumidor. São Paulo, Max Limonad, 1998.

MAGALLANES, Pablo Medina. O interesse segurável. In: III FÓRUM DE DIREITO DO SEGURO “JOSÉ SOLLERO FILHO”. São Paulo: Manuais Técnicos de Seguros: IBDS, 2003.

MAGEE, John H. Seguros generales. 2. ed. México: Unión Tipografica Editorial HispanoAmericana, 1947.

MARQUES, Cláudia Lima. Contratos no Código de Defesa do Consumidor. 4. ed. São Paulo: Revista dos Tribunais, 2002.

MARQUES, José Frederico. Manual de Direito Processual Civil. São Paulo: Saraiva, 1974. v. 1.

MARTINS, Fran. Contratos e obrigações comerciais. 14. ed. Rio de Janeiro: Forense, 1999.

MARTINS, João Marcos Brito. Direito do Seguro: responsabilidade civil das seguradoras: doutrina, legislação e jurisprudência: de acordo com o novo Código Civil, Lei 10.406, de 10.1.2002. 2. ed. Rio de Janeiro: Forense Universitária, 2004.

MEHR, Robert I.; CAMMACK, Richard. Principles of Insurance. Seventh Edition. Homewood, IL: Emerson D. Irwin, Inc., 1980.

MELLO FRANCO, Vera Helena de. Breves reflexões sobre o contrato de seguro no novo Código Civil brasileiro. In: FÓRUM DE DIREITO DO SEGURO JOSÉ SOLLERO FILHO, 2., 2001, São Paulo. II Fórum de direito do seguro. São Paulo: Instituto Brasileiro de Direito do Seguro, 2002. (Estudos de direito do seguro, v. 4).

MELLO, Marcos Bernardes de. Teoria do Fato Jurídico: plano da existência.15. ed. São Paulo: Saraiva, 2008a.

. Teoria do Fato Jurídico: plano da validade. 8. ed. São Paulo: Saraiva, 2008b. 
MELO, Gustavo de Medeiros. A ação direta do terceiro prejudicado no seguro de responsabilidade civil - uma análise do sistema jurídico brasileiro. Revista Brasileira de Direito do Seguro e da Responsabilidade Civil, São Paulo: MP Editora, 2009. p. 131-171.

MERKIN, Robert; BUTLER, John S.; GREEN, Alison A. Insurance Contract Law. London: Kluwer Publishing, 1992.

MEZZOMO, Marcelo Colombelli. Breves apontamentos sobre o contrato de seguro. Âmbito Jurídico, 25 nov. 2010. Disponível em: <hwww.ambito-juridico.com.br/site/ index.php?n_link=revista_artigos_leitura\&artigo_id=4687>. Acesso em: 25 nov. 2010.

MILONE, Giuseppe. Estatística geral e aplicada. São Paulo: Pioneira Thomson Learning, 2004.

MORANDI, Juan Carlos Felix. Estudios de derecho de seguros. Buenos Aires: Pannedille, 1971.

NEGREIROS, Teresa. Teoria do contrato: novos paradigmas. 2. ed. Rio de Janeiro: Renovar, 2006.

OSTEN, Hansgeorg V. Der. Manual de Seguros. Salamanca: Anaya, 1971. (Versão espanhola da obra original de Nutzbringerder Umgang Mit Versicherungen, Sttutgart, 1965.)

PASQUALOTTO, Adalberto. Os papéis da álea e da garantia no contrato de seguro: uma visão das leis portuguesa e brasileira. Revista dos Tribunais, São Paulo, n. 885, 2009.

PFEFFER, Irving; CLOCK, David R. Perspectivas del seguro. Trad. Juan Aldaz. Madrid: Mapfe, 1977.

PICARD, M.; BESSON, A. Les assurances terrestres. Paris: LGDJ, 1982. t. 1.

PIZA, Paulo Luiz de Toledo. Contrato de resseguro: tipologia, formação e direito internacional. São Paulo: Manuais Técnicos de Seguros: IBDS, 2002.

POLIDO, Walter Antonio. O seguro de responsabilidade civil geral no Brasil \& aspectos internacionais. São Paulo: Manuais Técnicos de Seguros, 1997.

PONTES DE MIRANDA, Francisco Cavalcante. Comentários ao Código de Processo Civil. Rio de Janeiro: Forense, 1974. v. I.

Tratado de Direito Privado: parte especial. Rio de Janeiro: Borsoi, 1964. t. XVI. 
PONTES DE MIRANDA, Francisco Cavalcante. Tratado de Direito Privado. Rio de Janeiro: Borsoi, 1964. t. XLV.

PROVOST, Magalie. La notion d'intérêt d'assurance. Paris: LGDJ, Lextenso Éditions, 2009.

RIBEIRO, Amadeu Carvalhaes. Direito de seguros: resseguro, seguro direto e distribuição de serviços. São Paulo: Atlas, 2006.

ROBELLI, Roberto. L'assicurazzione della responsabilità civile autoveicoli. Torino: Unione Tipográfico-Editrice Torinese, 1970.

RODRIGUES, Silvio. Direto Civil: dos contratos e das declarações unilaterais de vontade. 30. Ed. São Paulo: Saraiva, 2007. v. 3.

ROUX AZEVEDO, Luis Augusto. A comutatividade do contrato de seguro. 2010. Dissertação (Mestrado) - Faculdade de Direito da Universidade de São Paulo, 2010.

SANTORO-PASSARELI, Francesco. Dottrine Generali del Diritto Civille. 9. ed. Napoli: Jovene, 1983.

SANTOS, Amilcar. Dicionário de Seguros. 2. ed. Rio de Janeiro: Instituto de Resseguros do Brasil/Rio de Janeiro, Imprensa Nacional, 1948.

Seguro: doutrina, legislação e jurisprudência. Rio de Janeiro: Record, 1959.

SANTOS, Ricardo Bechara. Direito do seguro no novo Código Civil e legislação própria. Rio de Janeiro: Forense, 2006.

SHADAB, Houman B. Guilty by Association? Regulating Credit Default Swaps. Entrepreneurial Business Law Journal, p. 40. Disponível em: http://papers.ssrn.com/sol3/ papers.cfm?abstract_id=1368026>. Acesso em: 5 maio 2009.

SILVA PEREIRA, Caio Mario da. Instituições de Direito Civil - contratos. 12. ed. Rio de Janeiro: Forense, 2005. v. III.

SILVA, De Plácido e. Vocabulário jurídico. 10. ed. Rio de Janeiro: Forense, 1987. v. I-III. SILVA, Ivan de Oliveira. Curso de direito do seguro. São Paulo: Saraiva, 2008.

STEMPEL, Jeffrey W. Stempel on Insurance Contracts. $3^{\text {rd }}$ ed. New York: Aspen Publishers, 2007, v. I.

STIGLITZ, Rubén S. Derecho de seguros. Buenos Aires: Abeledo-Perrot, 2001. v. I-II. Objeto, causa y frustración del contrato. Buenos Aires: Depalma, 1992. p. 19-20. 
SZTAJN, Rachel. Seguro de dano moral resultante de acidente com veículo automotor. Revista de Direito Mercantil, Industrial, Econômico e Financeiro. São Paulo: Malheiros, n. 106, p. 25-37, 1997.

TEPEDINO, Gustavo; BARBOSA, Heloisa Helena; MORAES, Maria Celina Bodin. Código Civil interpretado conforme a Constituição da República. Rio de Janeiro: Renovar, 2004. v. I.

Código Civil interpretado conforme a Constituição da República. Rio de Janeiro: Renovar, 2006. v. II.

THE LAW COMISSION AND THE SCOTTISH LAW COMISSION. Insurance contract law. Issues Paper 4. Insurable Interest, 14.01.2008. Disponível em: <www.lawcom.gov.uk/.../Insurance_Contract_Law_Issues_Paper_4.pdf>. Acesso em: 15 ago. 2010.

TOMASETTI JUNIOR, Alcides. Abuso de poder econômico e abuso de poder contratual: consultas e pareceres. Revista dos Tribunais, São Paulo, v. 84, n. 715, p. 87-107, maio 1995.

Objetivo da transparência e o regime jurídico dos deveres e riscos de informação nas declarações negociais para consumo. Revista do Direito do Consumidor, São Paulo, n. 4, p. 52-90, 1993.

TORRES, Arnaldo Pinheiro. Ensaio sobre o Contrato de Seguro. Porto: Tipografia Segueira, 1939.

TZIRULNIK, Ernesto. Em torno do interesse segurável e da responsabilidade civil, In: ESCOLA PAULISTA DE MAGISTRATURA/EPM; INSTITUTO BRASILEIRO DE DIREITO DO SEGURO - IBDS. Seguros: uma questão atual. (Estudos de Direito do Seguro). São Paulo: Max Limonad, 2001.

; CAVAlCANTI, Flávio de Queiroz B.; PIMENTEL, Ayrton. O contrato de seguro de acordo com o novo Código Civil brasileiro. São Paulo: Revista dos Tribunais, 2003.

VENOSA, Silvio de Salvo. Direito Civil: contratos em espécie. 3. ed. São Paulo: Atlas, 2003. 